\title{
Private Enterprise in China
}





\section{Private Enterprise in China}

Ross Garnaut, Ligang Song, Yang Yao and Xiaolu Wang

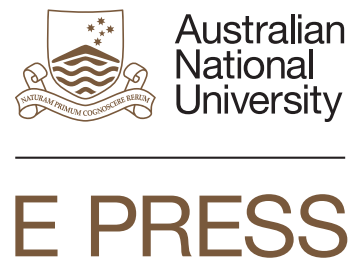




\section{ANU \\ E PRESS}

Published by ANU E Press

The Australian National University

Canberra ACT 0200, Australia

Email: anuepress@anu.edu.au

This title is also available online at http://epress.anu.edu.au

National Library of Australia Cataloguing-in-Publication entry

Title: Private enterprise in China / Ross Garnaut ... [et al].

ISBN: 9781922144478 (pbk.) 9781922144485 (ebook)

Subjects: Free enterprise--China.

Privatization--China.

Industrial policy--China.

China--Economic conditions--1976-

Other Authors/Contributors:

Garnaut, Ross.

Dewey Number: 330.1220951

All rights reserved. No part of this publication may be reproduced, stored in a retrieval system or transmitted in any form or by any means, electronic, mechanical, photocopying or otherwise, without the prior permission of the publisher.

\section{Printed by Griffin Press}

First published by Asia Pacific Press, 2001

This edition @ 2012 ANU E Press 


\section{Contents}

Tables

Figures and Boxes

Abbreviations

Preface

vii

viii

ix

$\mathrm{x}$

A summary overview of emerging private enterprise in China

Policy recommendations

Implications

xiv

xxii

1 Introduction

Objectives 1

Methodology of the survey 2

Sampling strategy 4

2 Development of the role of private enterprise in China 9

An historical perspective 9

Contributions of the private sector to the national economy 15

Evolution of private firms ownership 21

Sectoral and regional distributions of private firms 24

3 Descriptions of the sample enterprises 29

Profiles of the four surveyed cities 29

Size and industrial distribution $\quad 31$

Evolution and performance $\quad 37$

4 Market competition $\quad 42$

Macroeconomic conditions $\quad 42$

Market entry: openness and requirements 43

Competitors, partners and the role of network 46

Firms' reaction to the market conditions $\quad 50$

Appendix $4.1 \quad 52$

5 Finance 53

The financial position of the sample firms 53

Access to formal loans $\quad 59$

Other forms of private firms' financing $\quad 66$

Reforming the financial system $\quad 71$

Appendix $5.1 \quad 75$ 
6 Taxation $\quad 78$

China's new taxation system $\quad 78$

Problems in the implementation of the current taxation system 80

The distribution of tax burden $\quad 82$

$\begin{array}{ll}\text { Concluding remarks } & 89\end{array}$

$\begin{array}{lll}Z & \text { Internal governance } & 90\end{array}$

Ownership forms 90

Internal decision making $\quad 92$

Governance and industrial organisation $\quad 96$

Employee involvement and labour management 98

$\underline{8}$ Labour and managerial skills $\quad 100$

Skill profiles of managers and workers 100

Training and impediments to obtaining

and retaining skilled workers 104

$\begin{array}{ll}\text { Wage differentials } & 105\end{array}$

The new social security system and its impacts on private firms 106

2 Technological challenges $\quad 110$

The pattern of technological innovations 110

Factors affecting firms' technical capacities 113

The protection of intellectual property rights 115

10 Laws and government administrative regulations 117

Laws and regulations related to private firms and their impact 117

Regional differences in law enforcement

$\begin{array}{ll}\text { and administrative performance } & 120\end{array}$

Business intermediaries and government services as a

bridge for information dissemination

Business associations 125

Room for improvement $\quad 130$

Social consciousness and channels for private
entrepreneurs' voices

$\begin{array}{ll}\text { References } & 137\end{array}$

Index 138 


\section{Tables}

1.1 Summary statistics of received questionnaires 6

1.2 A comparison of Phase I and Phase II sample 7

2.1 Compostion of China's GDP, $1998 \quad 17$

2.2 Private firm development since 1991

2.3 Ownership structure of private firms 25

2.4 Capital size distribution of private firms 25

2.5 Sectoral distribution of private firms: workers 25

2.6 Sectoral distribution of private firms: output 26

2.7 Regional distribution of private firms: number of firms and workers $\quad 26$

3.1 Basic information of the four cities' private sectors in $1998 \quad 30$

3.2 Size distribution of sample forms: 1995 and 1998

3.3 Statistics of firm size 34

3.4 Sales and capital of sample firms: 1995 and 1998

3.5 Industrial distribution of sample firms, 1998

3.6 Growth of capital stock since the founding of the firm 37

3.7 Pre-tax profitability of sample firms by city: 1995 and $1998 \quad 38$

3.8 Pre-tax profitability by industry 39

3.9 Pre-tax profitability by firm size $\quad 40$

4.1 Types of entry barriers 45

4.2 Types of entry barriers by firm size 47

5.1 Sources of firms' initial capital $\quad 54$

5.2 Sources of capital financing 55

5.3 Turnover of working capital: 1995 and $1998 \quad 58$

5.4 Applications for formal loans by city 61

5.5 Loan applications by firm size 61

A 5.1 Fees collected for collateral appraisal and registration in $G$ autonomous region $\quad 76$

6.1 Tax contribution of the private sector: 1986-97 83

6.2 Difference between tax due and actual payment by firm size 84

7.1 Ownership distribution of sample firms: $1998 \quad 91$

7.2 Pattern of internal management 93

7.3 Certified accounting reports by ownership 93

7.4 Industrial organisation $\quad 97$

8.1 Educational profile of managers by city and firm size $\quad 102$

8.2 Former experience of managers by city and firm size 103

9.1 The distribution of new products by city and firm size 112

10.1 Power supply by city 122 


\section{Figures}

2.1 Workers in the private sector 1981-97 12

2.2 Share of employment in private sector in national total 1981-97 13

2.3 Industrial output of private sector 1980-97 18

2.4 Share of private sector industrial output in national total 1980-97 18

2.5 Ownership shares in China's GDP: $1998 \quad 19$

2.6 Private sector including agriculture in total GDP: 1998

\section{Boxes}

2.1 Shunde's privatisation 22

2.2 Gaizhi in Sichuan province $\quad 23$

4.1 W Arts Co. Limited 46

4.2 Firm J's conquest of the market 48

5.1 Firm Y's journey to get a bank loan 63

5.2 Bank finance in Wenzhou $\quad 69$

6.1 Firm S's local taxes and fees $\quad 87$

6.2 Fees collection and government corruption 88

7.1 Changing ownership and internal governance in private firms 95

9.1 MD: Development by way of innovations 111

9.2 Intellectual property rights and technical innovation 116

10.1 Firms P's loss of its land 121

10.2 Guizhou Chamber of Commerce 128

10.3 Wenzhou Garment Chamber of Commerce 129 


\section{Abbreviations}

ACFIC

APSEM

BET

BICM

CASS

CCER

CCP

$\mathrm{CEO}$

CV

Getihu

ICBC

IFC

MLSS

MOFTEC

MSB

NPC

$\mathrm{PBOC}$

$\mathrm{R} \& \mathrm{D}$

SETC

SOB

SOE

SSB

TSPE

TSRIPE

TVE
All-China Federation of Industry and Commerce Asia Pacific School of Economics and Management Bureau of Economics and Trade Bureau of Industry and Commerce Management Chinese Academy of Social Sciences China Center for Economic Research Chinese Communist Party chief executive officer coefficient of variation Single business proprietor

Industrial and Commercial Bank of China International Finance Corporation Ministry of Labour and Social Security Ministry of Foreign Trade and Economic Cooperation Min Sheng Bank

National People's Congress

People's Bank of China research and development State Economic and Trade Commission state-owned bank state-owned enterprise State Statistical Bureau Tentative Stipulations on Private Enterprises Tentative Stipulations on the Registration of Individual and Private Enterprises

township and village enterprise 


\section{Preface}

The book reports and interprets results from a detailed study of the contemporary private sector in China. It is based on the Technical Report on Private Enterprise Development in China commissioned by the International Finance Corporation (IFC) and the State Economic and Trade Commission (SETC) of the People's Republic of China.The research was undertaken by a team from the Australian National University and Peking University. The Report to the International Finance Corporation has been augmented by additional materials, for example on social perceptions of private enterprise, for this book. Readers' attention is also drawn to the important publication by Gregory, N., Tenev, S. and Wagle, D. China's Emerging Private Enterprises: Prospects for the New Century (International Finance Corporation, 2000).

We gained a great deal from the officers of the IFC, including Neil Gregory, Dileep Wagle, Stoyan Tenev, Davin Mackenzie and Jianguo Cui and officials from the State Economic and Trade Commission (SETC), $\mathrm{Mr}$ Wei Dong (Director General, Small and Medium Enterprise Department) and Mr Tian Chuan (Deputy Director, Small and Medium Enterprise Department). We thank IFC and SETC for their permission to publish this work. We also thank various government and non-government institutions including the All-China Federation of Industry and Commerce (ACFIC) and their regional offices for providing the research team with important support during the fieldwork in the four cities in which surveys were conducted.

The funding for the project upon which this book is based came from IFC and AusAID. We would also like to thank Asia Pacific Press for publishing the book and, in particular, Mikaela Wilson and Tracey Hansen.

Ross Garnaut, Ligang Song, Yang Yao, Xiaolu Wang Canberra and Beijing

May, 2001 


\section{A summary overview of emerging private enterprise in China}

The Chinese economy is currently undergoing its third great institutional transformation of the reform period. This transformation is as profound as the replacement of the peoples communes with the household responsibility system in the early 1980s and the emergence of township and village enterprises as the main locus of economic dynamism in the second half of the 1980s. The third transformation is the emergence of the private sector as the main focus of economic growth. Like the two preceeding transformations of the reform era, it has proceeded quietly and swiftly, building upon an emerging reality, with change accelerating once the authorities have recognised the benefits of the reality and given official blessing to continuation of the transformation.

A constitutional amendment acknowledging the importance of the private sector was adopted during the 1999 sessions of the National People's Congress. It

- provides a legal basis for private enterprise in the economy

- makes official recognition of the important emerging reality, that a majority of the growth in non-farm employment and output is in the private sector despite the continued tendencies for capital and government services to be allocated disproportionately to state-owned enterprises

- allows individual enterprises to take off their 'red hats', thus reducing uncertainty in the business environment

- allows the official policy and regulatory environment to be refocused to remove impediments to continued dynamism in a major, and soon the major, part of the economy.

The private sector was suppressed in China during the period of central planning (1957-78). It has re-emerged since reform started in the late 1970s and has grown quickly in the past 20 years. The number of registered private firms and employment in them, as well as their share in total GDP, is growing even more rapidly in the improved policy environment for private business that was established in the late 1990s. 
The non-state sector now accounts for 62 per cent of total economic activity. Within this total, there are difficult matters of definition in drawing the dividing line between genuinely private and 'collective' enterprises. On our best estimate, the private sector, including household production in agriculture, accounts for 50 per cent of the total. This proportion will now grow rapidly for two reasons.

First, the component of the 'collective sector' that is in reality private will grow rapidly, as the regulatory and ideological advantages of a real or nominal 'red hat' diminish. Just as the collective sector has effectively disappeared in recent years in the municipality of Shunde, so it will recede in other areas.

Second, the state-owned sector will continue to decline as a proportion of total output, just as it has, despite regulatory advantages, over the past two decades. The non-state sector-at first agricultural households and collectives, and increasingly private enterprises outside agriculture - has used resources more effectively and grown more rapidly than state-owned enterprises.

The success of the private sector in a regulatory environment overwhelmingly geared to the requirements of state-owned enterprises is remarkable. The reform of the regulatory and institutional framework to provide more congenial conditions for the most dynamic and now the larger part of the Chinese economy has the capacity to unleash large, new potential for economic growth.

The development of the private sector at this stage of economic transformation plays an important role in a number of areas.

- It increases employment both by recruiting new workers into the non-farm economy and by absorbing laid-off workers from reformed state-owned enterprises (SOEs).

- It creates competition, nurtures entrepreneurship and instigates innovation.

- It helps channel an increasing part of social funds into more efficient uses and hence increases the overall efficiency of the economy.

- Meeting the demands of the private sector can help build an institutional framework which is more compatible with a market system, thereby facilitating improved performance in state-owned and collective enterprises.

- Private enterprises as a new source for growth can play an important role in achieving the objective of restoring growth momentum after a slowdown during and after the financial crisis elsewhere in East Asia.

- Private firms in China are subject to a hard budget constraint so that their expansion does not carry the same risks to macroeconomic stability as the expansion of state-owned enterprises. 
But, in a country whose production and commercial activities have been dominated especially by large SOEs for decades, there is still much discrimination against smaller and private enterprises in areas such as business registration, taxation, financing and the right to engage in foreign trade. Furthermore, public perception of the private sector has not yet changed as much as the economic reality that is reflected in official statistics. A considerable task remains, to allow the participation of private firms in developing China's economy, including its foreign trade, to reach its full potential.

The development of the private sector in a transition economy like China hinges on several things.

- The private sector needs to operate and develop within genuine market conditions. Thus, further market-oriented reform is essential.

- To establish genuine market conditions, the rule of law needs to be established to protect private ownership and contract rights and to clearly define private obligations.

- Development of the private sector also requires adjustments in the functioning of the government.

- The establishment of effective market institutions will guide private enterprises into productive profit-seeking and innovation rather than unproductive rent-seeking activities.

- Development of the private sector needs to be accompanied by social and political measures from government and pressure from the public in order to deal with such associated problems as income disparities and social protection.

China has begun to tackle these issues and some measures aimed at encouraging private sector development have been introduced. Most important has been the simple recognition of the sector in the constitution and state policy. Within this context, a large number of small and mediumsize SOEs are currently being restructured based on market conditions in which private firms are allowed to play an important role. This is proceeding so rapidly in some areas that it is called the 'quiet revolution'.

Financial and labour markets are rapidly developing. A new management (governance) structure is taking shape among established and new non-state firms. Social safety nets are being built. State commercial banks have been asked to assist in the development of small firms including private enterprises by introducing flexible lending interest rates, which can be varied in response to market conditions including perceptions of risk. From the beginning of 1999 (for the first time since 1957) some private enterprises were granted licenses to conduct foreign trade. More and more sectors including financial services have been opened to foreign competition. 
There are still many problems associated with the development of private enterprises in China. For example

- unwarranted fees and taxes are still being levied on private enterprises by local governments

- private firms still find it difficult to obtain to business finance, particularly from state financial institutions

- there is a need for efficient and transparent bank loan guarantee systems for small and medium-size firms, including private enterprises

- there is a need to improve the skill base of private enterprises, particularly those of medium and small size, at both managerial and employee levels

- there needs to be greater transparency of private enterprises in management and operation, particularly in their accounting and auditing practices

- private enterprise still doesn't have and should be provided with access to efficient government sources related to business registration, land use, finance, market entry and law enforcement

- the legal and regulatory environment needs to be streamlined

- markets need to be developed for inputs into production, especially finance and labour

- a more competitive environment in which all firms compete on an equal footing is yet to be established.

Overall, there is much that could be done to enhance the contribution to development of this dynamic sector of the economy.

\section{Policy recommendations}

The Survey results, discussed in this book, and analysis based on the Survey, suggest the following policy recommendations for the development of private enterprise in China.

\section{Reforming the financial system}

The uneven distribution of bank loans between the state and non-state sectors is a major constraint on further development of the non-state sector, particularly small-size private enterprises. It results in inefficient uses of bank funds. In 1998, the non-state sector contributed 71 per cent of industrial gross output value. However, its share in total bank loans has been minor (SSB 1999).

According to the Industrial and Commercial Bank of China, a major state bank, by 20 June 1999, only 20.9 per cent of its short-term loans were to nonstate enterprises. Most of the non-state recipients of loans were collective and foreign-owned enterprises. Domestic individual and private enterprises shared 
only 0.5 per cent of total short-term loans ${ }^{1}$. The Survey found that small private enterprises find it difficult to get a bank loan.

It may be, but it is not obviously the case, that loans extended to small enterprises have a higher risk than those to larger enterprises. The appalling record of non-performing loans to large state enterprises makes the opposite suggestion. The financial constraint on small private enterprises seriously restricts their development and growth.

To solve the problem, the following policy changes and steps are recommended.

1. Policies of state banks should be adjusted to treat the state and non-state including private enterprises more even-handedly. Financial institutions particularly state banks should develop policies and plans to overcome non-commercial obstacles to making loans to private enterprises.

2. The current policy of zero risk lending, applied mainly to non-state enterprises, should be replaced by judging performance on the overall management of a portfolio. A bank branch or an employee would be evaluated by the profitability of the resources allocated in a certain period, not simply by whether one or two loans had been lost. They would not be evaluated differently according to whether the borrower was a state or a private enterprise.

3. This outcome would be achieved naturally as a consequence of requiring the state banks to operate competitively and profitably within a rational system of prudential supervision, which systematically discounted non-performing assets independently of the identity of the borrower, and which required maintenance of minimum ratios of capital to assets, all within a transparent accounting framework. The second recommendation is therefore best implemented through completion of the system-wide financial reforms that are in any case required for future economic stability.

4. To give incentives to banks to extend loans to small enterprises, to cover their perceived risk of losses, and to eliminate rent-seeking behaviour, a flexible interest rate is needed. Controls on lending rates can be eased to allow banks to charge different rates according to the risks of loans. The years following the Asian financial crisis extending at least through 2002 are a good time to carry out interest rate reform because the economy is not experiencing inflationary boom conditions, and liberalisation will not lead to the interest rate being pushed too high by demand for funds. ${ }^{2}$

5. To finance small and medium-size enterprises, there is a need to develop new non-state financial institutions. Many local non-state 
financial institutions have been eliminated, including those which operated well, as a consequence of new prudential regulations in the late 1990s that were designed to reduce systemic risk to the financial sector. A new policy should allow non-state financial institutions to grow, within reasonable prudential supervision by the state. Rules that effectively apply a total ban on all new financial institutions is inappropriate. In this context, it would be advantageous to allow more private banks to operate.

6. The current quota system for entering the stockmarket has given priority to state enterprises. This has resulted in inefficient use of financial capital and less chances for more efficient private firms to raise investment funds through stockmarkets. It is recommended that state and non-state enterprises should have equal access to finance on stockmarkets on terms that vary only with market-related characteristics.

7. Within the context of allowing the emergence of new non-state institutions, and allowing more equitable access to stockmarket issues, special care should be taken to remove current impediments to the provision of 'venture capital'. By 'venture capital' we mean the provision of capital at a high price to activities that are perceived as having high risk but which carry the possibility of high reward.

8. It is important that the regulations governing the listing of shares in established firms, including state-owned enterprises, allow the sale of 'old' as well as 'new issue' shares to facilitate capitalisation of the fruits of successful efforts in establishing new enterprises.

9. Loan guarantee funds or systems, if appropriately designed, can help to resolve financing problems facing private enterprises. Such systems need to be run efficiently and transparently in order to avoid moral hazard and cronyism. Contributions from the private sector into such funds help to increase available funding, improve efficiency of management, reduce moral hazard and strengthen accountability. From the current study, it seems that guarantee funds, outside the public policy sector, would contribute to a solution to small and medium firms' financing problems.

10. The current asset evaluation system for private enterprises in applying for a bank loan is counter-productive. Complicated procedures and high fees deter potential applicants. The system needs to be reformed by simplifying the assessment procedures and rationalising fees. For example, fees should be progressively lower for firms that have established their credit-worthiness through a good repayment record on loans for which they are seeking refinancing. 


\section{Further reforming government taxation and revenue system}

The Survey found a number of problems for small and for private firms in the current tax system and the government collection of fees. These problems can be summarised as follows.

- Although the tax burden is low compared with other countries (the government budgetary revenue accounted for only 12 per cent of GDP in 1998), there are massive irregular fees, fines, and involuntary 'donations' collected by various government departments at the different administration levels.

- Some estimates suggest that the amount of non-budgetary government revenue, is no less than the formal budgetary revenue. Our Survey finds that the amount of fees collected from firms was smaller than taxes paid, but nevertheless considerable.

- An important reason for the extent of revenue raising through fees is the conflict between the decentralised government role and the centralised tax legislation. Local governments are not allowed to adjust the rate of local taxes or create new taxes to meet their needs. Instead, they irregularly and arbitrarily collect fees. The absence of democratic monitoring of government behaviour facilitates the continuation of irregularities. Without effective supervision, some fees come to be applied to the personal interests of government officials.

- The heavy collection of fees increased burdens on enterprises, caused unnecessary uncertainty; and distorted market signals and firms' incentives. It was also a source of government corruption.

- The actual tax burden among firms is uneven. The variation is much greater in relation to fee collection. The Survey results indicate that fees are higher as a proportion of sales for smaller than for larger firms. Data from the sample firms show that firms with up to $50,51-100,101-500$, and above 500 employees pay tax and fees totalling $11,9.5,9.3$, and 7.6 per cent respectively of total sales. This reflects the fact that large firms have more opportunity for tax privileges. The amount of tax and fees also varies across regions.

- Fees, and in some cases taxes, are often collected arbitrarily depending on government officials' personal judgment. They are not transparent and frequently related to rent-seeking behaviour of government officials.

- The current tax system discourages investment and technical innovation by enterprises. This is mainly because investment in capital assets and $R \& D$ does not attract deductions in assessment of value-added tax and income tax. 
With consideration of the above problems, some policy changes and reform measures are recommended.

1. There needs to be a systematic effort to place the revenues of lower levels of government on a sound footing. The government is trying to solve the irregular fee collection problem by absorbing some fees into the tax system. However, this is unlikely to satisfy all the needs of local governments in different regions with different levels of development. Some taxation powers and rights to revenue should be decentralised. For this to achieve the desired objectives, a more democratic monitoring system for local governments is needed, partly replacing the role of central supervision.

2. The tax system should be made more transparent and more equitable in its application across firms. Opportunities for arbitrary interpretations of tax laws and regulations need to be eliminated. The tax system should be reformed to allow full deductions for expenditure on investment and innovation in assessment of value added tax and income tax.

3. For fairness and efficiency in tax collection, efforts need to be made to help small enterprises to improve management and accounting systems. This is partly a matter of education and training of personnel, and partly of consciousness-raising for key managers and leaders. The best results are unlikely to be achieved from government initiative alone, although government and such public institutions as All China Federation of Industry and Commerce (ACFIC) have an important role in framing the discussion.

4. Accounting and auditing services should be arranged to meet the increasing needs of private firms especially small firms. The government role is to insist on transparent reporting of financial data according to clearly articulated standards, to support education and training in related fields, and to facilitate the development and operation of professional firms providing these services, including through entry of foreign firms.

5. The taxation system itself must be well disciplined. Rent-seeking behaviour, in all forms, by government officials and departments, should be strictly prohibited. Again, clear rules, capable of simple enforcement, and specialised education and training, are the key ingredients of reform. 


\section{Government reform}

Two other important reasons for raising the financial burdens in forms of fees on private enterprises is the over-expansion of local governments and rentseeking behaviour of government officials.

The roles of government departments are not clearly defined. Some old government institution functions that are not compatible with a market system have been becoming obsolete. There is overlap in functions among government departments. In some areas, the heavy government burden on firms has become the major obstruction to economic growth.

Because of the expansion of market elements in the economy, the room for rent-seeking behaviour has been reduced. This rent-seeking behaviour is no longer active in input distribution, fund distribution, price control, and import and export controls. However, such behaviour appears to have become more serious in areas of government administration that cannot be subject to market disciplines. They include taxation, legal/regulatory action, public security and local community administration.

Rent-seeking behaviour is also rampant in those institutions that cannot be fully subject to market disciplines. They include institutions concerned with administration of land use, pollution control, health and safety supervision, technology and quality standard of products. Rent-seeking behaviour has significantly increased the business costs to firms and hampered their development.

Reforms in government itself are necessary. The following are recommended as being important to the development of the private sector

1. re-examining, redefining and clarifying the functions of government departments at different administrative levels according to the requirements of a market economy. Changes must be allowed in the structure of local governments in different regions to meet different needs resulting from different circumstances in those regions

2. reducing the size of governments according to the clarified roles of departments, and eliminating unnecessary government departments or organisations affiliated to governments

3. the discipline of the governments must be emphasised by strengthening both the central supervision and local monitoring system with democratic modalities. Rent-seeking behaviour of all kinds must be prohibited

4. interference by governments at different levels in enterprise operation that has no clear legal basis should be prevented. 


\section{Policies on technical innovation}

Although private enterprises are active in technical innovation, there are several major constraints for their investment in research and development (R\&D) and other activities conducive to development of technological capabilities. These constraints include shortages and weaknesses in human capital, financial resources, information and effective protection of intellectual property rights.

In the past two decades, economic growth in China was accelerated mainly by the effects of market-oriented economic reform in improving resource allocation, efficiency in production and openness to foreign ideas, methods and competition. Government and business alike paid insufficient attention to education and other investments in human capital, partly due to the lack of funds. The growth rate of human capital, measured crudely by numbers of educated workers in the labour force, was slower in the reform period than in the pre-reform period (Wang 1999).

Other countries' experience shows that fast economic growth cannot be sustained without significant acceleration of human capital growth. To meet this condition of sustained rapid growth, the government needs to invest heavily in education and R\&D. Government could lessen its financial burden in developing education by allowing investment by the domestic and foreign private sector. Investment in education in relevant business skills is particularly important now to the private sector.

China lacks financial institutions that deal with investments in R\&D, and more generally venture capital, which has high risk but high potential returns. The government is embarking on establishing various kinds of funds for the purpose of research and development. Again, non-government institutions should also be allowed and encouraged to participate in these efforts.

It is important for information service systems to be effective, especially for small business. More commercial information and knowledge is required in relation to technology, international and domestic goods and services markets, factor markets and management. This is best achieved by facilitating the emergence of new businesses providing these services on a market basis, especially in the private sector. A more competitive telecommunications system, providing basic services at international prices would help.

\section{Legal protection of property rights}

To safeguard technical innovation, an improvement and strengthening of the legal system is warranted. This will strengthen incentives for enterprises to invest in $R \& D$ and promote innovation.

The common phenomenon of debt repayment arrears and bad debts between firms for private firms can be traced to the lack of legal protection for private property rights. This results in disorder in the market and high costs to legitimate 
firms as well as to the economy. Protection of property rights should be legislated more clearly and should be enforced more effectively.

Generally the legal system needs to be further improved, with a strengthening of law enforcement to curb irregularities, and reduced transaction costs.

\section{Education and training}

It is a theme of these recommendations that there needs to be considerable investment in human capital with relevance to public and private regulation and governance of a market economy. Relevant areas of education and training include business law, accounting, auditing, business and public administration, as well as specialized areas including finance and economics.

There are private (for the individual who undertakes the education or the firm which contributes to employee education) as well as public benefits from expenditures on business-related education and training. There is therefore a case for partial but not full public subsidy for these activities.

Care needs to be given to the mechanisms through which elements of public provision of business education and training are delivered. Not all established educational institutions are suitable for training in business-related fields directed at the effective operation of a market economy.

What is required is flexibility, competition, and openness to domestic and international concepts and market pressures. This is likely to be achieved by providing additional public subsidy not directly on expansion of existing institutions, but as vouchers allocated competitively to qualified students, and redeemable at any properly credentialled institution, including new, private educational institutions. This would support the expansion of new institutions delivering in business-related education services that are perceived in the market-place as having high value.

\section{Opening up more areas (sectors) for private investment}

China's likely accession to the World Trade Organisation (WTO) in 2001 requires new steps in its liberalisation program and adjustments in its regulatory framework. Such changes and adjustments are consistent with the current policy shifts towards accommodating the development of the private sector in the Chinese economy. One area that needs further policy action is to open up more areas for private investment and trade.

- All sectors except those in which the State has predominant control should be open to private investment.

- The Law on Protection Against Unfair Competition (enacted in December 1993) to create a fair and competitive business and investment environment needs to be strictly implemented.

- Preferential policies towards SOEs and foreign investments need 
to be gradually phased out and a policy of national treatments to enable domestic private enterprises to compete with SOEs and foreign firms on an equal footing needs to be adopted.

- Foreign trading rights should be extended to all qualified private enterprises to allow direct and wider participation by private enterprises in China's foreign trade.

\section{Implications}

Several implications for the Chinese economy, reform program, governments, private enterprises and foreign investors (donors) can be drawn from the study.

\section{For the economy and reform}

The development of private enterprise was steady during the early years of the reform then accelerated from the early 1990s. Private businesses have made great contributions to the growth of the Chinese economy. We expect that the private sector will contribute much more than half the increase in China's economic output over the next ten years. Further liberalisation and institutional reform hold the key to utilising fully the private sector's contribution.

\section{For governments}

Amongst the many implications for government, one stands above others. Governments at all levels should be more consistent with and less arbitrary in their approach and policies towards private enterprise. The construction of the right policy, legal and regulatory framework will have a large pay-off in terms of more rapid development of private economies.

\section{For private enterprises}

Many of the lessons of the study are for private enterprises themselves. The key point is that private business should endeavour to focus more on the market, rather than government bureaucracies. To grow to their full potential, they will need to rely more on external financing, especially financing from equity markets, which will require more transparent accounting and lines of authority, and the provision of more reliable information into the market place.

\section{For International Finance Corporation (IFC)}

There is a growing demand from the private sector for expertise and training aimed at enhancing their development. Including areas such as financing, corporate planning and governance, management skills, business strategy, marketing, and technological know-how, etc. The IFC is well placed to provide such services to some enterprises. 


\section{Notes}

1. Information is obtained from an interview with the Industrial and Commercial Bank of China (ICBC) senior officials.

2. It is reported by the time of writing this report that the Central Bank would move to loosen the tight restriction on interest rates, allowing banks wider discretion in setting lending rates based on credit risk starting from 2000 . Chinese banks are now required to offer rates within 20 per cent of the central bank's official level, which means a window of just 0.45 percentage points on the benchmark one-year deposit rate of 2.25 per cent. 



\section{1}

\section{Introduction}

This introductory chapter specifies the main objectives and introduces the methodology and the sampling strategy of the study.

\section{Objectives}

The objectives of the study are to

- describe and analyse the nature (size and structure) and dynamics (change over time) of the Chinese domestic private enterprise sector ${ }^{1}$

- identify the main constraints to its development including in the regulatory and institutional environment

- assess and discuss the state of reform as it affects the private sector

- identify the opportunities for growth and investment associated with the development of the private sector

- make policy recommendations for supporting the development of the sector.

\section{Structure of the book}

The book discusses the following matters relating to the development of private enterprise in China: market competition; finance; taxation; internal governance; labour and management skills; technological challenges; laws and government administrative regulations. The focus of the book is on these matters as they arise directly from analysis of the Survey results. Some other sources of information, such as official statistics, research reports and other publications, are also drawn on when appropriate. The book also provides a more general picture of the development and role of private enterprise in the Chinese economy. ${ }^{2}$

This book presents basic tabulations, derived from both firm level and cheif executive officer (CEO) questionnaires which illuminate key features of the surveyed private enterprises and key issues surrounding CEOs' opinions. 
The book also presents in boxes some stylised descriptions of private businesses, including social profiles of the private entrepreneur. The boxes present some successful and some unsuccessful cases. They tell stories which illustrate some typical challenges facing private firms, for example how changes in government policies affect the operation of businesses.

The book offers conclusions and recommendations to the Chinese government on issues, such as the improvement of the existing institutional and policy framework, which have direct implications for the growth and development of private enterprise and the government's reform agenda.

\section{Methodology of the Survey}

With the support of the State Economic and Trade Commission (SETC) and the International Finance Corporation (IFC), the research team from the Asia Pacific School of Economics and Management (APSEM) of the Australian National University, and the China Center for Economic Research (CCER) of Peking University conducted a large sample Survey in Beijing, Wenzhou (Zhejiang Province), Shunde (Guangdong Province) and Chengdu (Sichuan Province) on the private sector in July/August 1999.

The study included both the Survey and interviews with officials. The main Survey consisted of three parts: mail-out firm level questionnaires; interviews with chief executive officers (CEO); and interviews with officials at both central and local levels. The main Survey was preceded by a pilot Survey at the end of June 1999 and a launch workshop in Beijing at the beginning of July 1999. Two questionnaires were utilised in the Survey. One was a firm level questionnaire that contained structured questions on factual aspects of a firm's operation and development. These questions were to be answered by company officers designated by CEOs, such as deputy managers or chief accountants.

Altogether 1,600 firm level questionnaires were posted to the randomly selected firms in Beijing, Wenzhou, Shunde and Chengdu (400 in each place) at the beginning of the fieldwork. In response to a low return for the initial mail-out Survey, a little more than 800 additional questionnaires were distributed in the course of the fieldwork both through direct posting and through official channels in the four cities plus two additional cities from Sichuan Province. The total number of the mail-out questionnaires was around 2,400 . With a final collection of 628 firm level questionnaires, a response rate of 26.2 per cent was achieved. ${ }^{3}$

During the June-July period, the research team collected laws and regulations pertinent to the development of private enterprises as well as national and regional level statistics on the size and growth of private business. 


\section{Firm level Survey}

The firm level Survey was implemented by mailing out the questionnaires to the firms chosen in the sample. Two official letters, one from SETC and the other one from local government agencies, such as provincial or metropolitan Bureaux of Industry and Commerce Management, were included in the mail-outs. The letters explained the Survey background and asked firms to fill out and return the questionnaires within ten days of receipt. Pre-paid envelopes with return address were included in the mailouts to facilitate the return.

\section{CEO interviews}

The second questionnaire was designed for use in the CEO interviews, and had both structured and open-ended questions. The structured questions were filled in by CEOs during interviews. ${ }^{4}$ The open-ended questions were asked by the research team members during interviews. The team members guided the interviews with CEOs with the key issues in their minds. The open-ended questions elicited CEO's opinions on the most important and pressing issues facing private enterprise and the changes that were needed to improve the business and policy environments in which private enterprise operates. The more detailed responses to the open-ended questions were a good supplement to the data from the firm level Survey. A subset of 200 of the 600 surveyed private enterprises in each of the four locations was targeted for the structured CEO interviews.

In each city, some private firms were recommended by local government agencies for the structured CEO interviews. Some were recognised because of their outstanding performance or because they had unique features in economic transformation, such as success in taking over inefficient stateowned enterprises (SOEs). The CEO interviews recommended by local government were useful in providing some insights into key issues involved in the development of private firms.

\section{Interviews with official and non-official institutions}

The interviews of officials focused on three types of government institutions: financial institutions including the Central Bank; tax and regulatory agencies; and policy agencies. Interviews with non-official institutions covered commercial banks, and rural credit unions. Interviews with some associations or societies for private enterprises and foreign investors were also carried out in some locations. These interviews with officials and others provided wider perspectives on the issues identified in discussions with private enterprises.

A structured list of questions for the key areas of interview of officials and others was prepared. The interviews were conducted at both the central and local 
levels in two stages. The first stage interviews at the central level were undertaken before the main Survey. The second stage interviews were undertaken after the main Survey to ensure that feedback from the Survey was taken into account in the structured questions, making the follow-up interviews more effective.

The data collected through the two questionnaires were stored electronically. Most of the CEO and government interviews were recorded and a written record was kept for each interview. These written records are the basis for some of the boxes in the book which portray interesting aspects of the history or operations of a typical private firm, or the effects of changes in certain government policies on the operations of private firms.

\section{Sampling strategy}

\section{Localities}

Four cities (Beijing, Chengdu, Shunde and Wenzhou) were chosen as the study sites to provide a range of characteristics with regard to the development of the private sector. ${ }^{5}$ Beijing, as the national capital, provides an opportunity to observe how private enterprises emerge and develop in the place of maximum political and ideological sensitivity, and regulatory controls. Another characteristic of Beijing is that it has witnessed rapid development of high-tech industries in its non-state sector in recent years, principally as a result of the location of many of China's top scientific and technological universities and research institutes in the city. Chengdu is the capital of Sichuan Province and presents a case study of private enterprises in inland areas, and Chengdu has maintained a remarkably strong record of private sector development. Shunde is a county-level city in the Pearl River Delta in Guangdong Province and a star in private sector development. In the 1980s, it was renowned for its township and village enterprises (TVEs). Starting in the early 1990s, it privatised almost all of its state-owned enterprises. Wenzhou has been long renowned for its private economy and is the first city in the country in which private entrepreneurs and enterprises flourished.

This study does not provide a representative sample of private enterprises across the whole of China. Rather, it provides a picture of the private sector in a range of cities in which private enterprises have been important in the local economy. The data from these selected cities reveal the problems and constraints facing private enterprises in China today, at different stages of private sector development.

\section{Stratified random sampling approach}

A stratified random sample was adopted in the study. Non-manufacturing firms were excluded from the sample. ${ }^{6}$ The ratio of rural to urban firms to 
be sampled in each city was kept roughly the same as the ratio of rural to urban firms in that city. This was achieved by the random selection of firms within rural-urban strata in each city. The share of each type of ownership-privately controlled collective, majority domestic privately owned joint stock enterprise, majority domestic privately-owned joint venture-was kept roughly the same as its respective share in the population. ${ }^{7}$ Finally, a number of high-tech enterprises was included in the sample to ensure representation of this newly emerging group. Firms were selected randomly within each stratum to generate a sample of 400 private manufacturing firms in each of the four cities.

Firms were chosen from the database constructed and maintained by the Bureau of Industry and Commerce Management in each city. ${ }^{8}$ The sample selection and mailing-out of the questionnaires was implemented in two stages. In the first Stage, 400 firms were randomly chosen from the BICM database in each city. The firm questionnaire was mailed out to the selected firms from each city. To allow efficient allocation of resources, the selection of firms for $\mathrm{CEO}$ interviews was concentrated in a few counties and districts in Beijing and Wenzhou. In Chengdu, the selection of a few counties and districts was undertaken separately after the city-wide selection from the data base had been completed. Because Shunde is a county-level city, all its townships were included in the sampling process. A total of at least $50 \mathrm{CEO}$ interviews was carried out in each city.

In the second Stage, the additional 200 firm questionnaires were mailed out by the research team in Shunde and Wenzhou, and 340 (some of them accompanied by the CEO questionnaire) were mailed out by the BICM in Beijing. ${ }^{9}$ In Sichuan, in addition to the additional mail-outs of 200 in Chengdu through the Provincial All China Federation of Industry and Commerce (ACFIC), 100 firm and CEO questionnaires were also mailed out in two other cities, Mianyang and Deyang, which are relatively close to Chengdu and where many medium and small-size private firms are concentrated.

The rule for choosing the additional firms was similar to that used in the first Stage. Measures were taken to ensure that there was no overlapping in selection of firms between the two Stages. As in the first Stage, the questionnaires were filled out by the selected firms themselves. However, unlike in the first Stage, the questionnaires in the second Stage were sent, collected and mailed back to the research base by the local government agencies (Beijing and Chengdu). As a result, the research team had to rely solely on the written answers to the additional CEO questionnaires without the support of the CEOs' oral responses to the more open-ended questions as in the first Stage. As a result, the more subtle, qualitative insights into the development of the private sector are derived from interviews in the first stage of the Survey. 


\section{Analysis of the final sample}

Table 1.1 summarises statistics on the firm and CEO questionnaires returned by city. A total of 628 firm questionnaires (189 in the first Stage and 439 in the second Stage) and 338 CEO questionnaires (160 in the first Stage and 178 in the second Stage) were returned. The number of firms returning both the firm and CEO questionnaires is 297 (119 in the first Stage and 178 in the second Stage). In addition, more than 200 CEOs (firms) were interviewed by the research team in the first Stage ( 55 in Shunde, 52 in Wenzhou, 53 in Beijing and 53 in Chengdu). The statistics shows that the response tates were high in the second Stage indicating that the official channels of distributing and collecting the questionnaires were effective in generating references.

Table 1.2 presents a comparison of the data obtained from the two Stages. This comparison shows that firms Surveyed through the second Stage are on average smaller than those in the first Stage in terms of employment, sales and fixed capital. In other words, the second Stage sample contained a proportionately greater number of smaller firms. The statistics also show that the two samples have a similar distribution pattern as demonstrated by their respective coefficients of variations (CV), although their means are quite different. In view of the mean differences between the two samples, they are complementary to each other in that the second Stage sample includes a proportionately greater number of medium and small-size private firms. The size difference between the two samples may be partly caused by the upper-tail bias created in Stage I sample because some of the firms, especially those with the CEO interviews, in this Stage were recommended by local governments because they were flagship enterprises to be interviewed.

Table 1.1 Summary statistics of received questionnaires

\begin{tabular}{|c|c|c|c|c|c|c|c|c|c|}
\hline \multirow{3}{*}{$\begin{array}{l}\text { City } \\
\text { Beijing }\end{array}$} & \multicolumn{3}{|c|}{ Received firm } & \multicolumn{3}{|c|}{ Received CEO } & \multicolumn{3}{|c|}{ CEO and firm matched } \\
\hline & \multicolumn{3}{|c|}{ Total Phase I Phase II } & \multicolumn{3}{|c|}{ Total Phase I Phase II } & \multicolumn{2}{|c|}{ Total Phase I } & \multirow{2}{*}{$\begin{array}{c}\text { Phase II } \\
66\end{array}$} \\
\hline & 354 & 33 & 321 & 99 & 33 & 66 & 93 & 27 & \\
\hline Shunde & 54 & 54 & - & 32 & 32 & - & 24 & 24 & - \\
\hline Chengdu & 88 & 50 & 38 & 86 & 53 & 33 & 73 & 40 & 33 \\
\hline Wenzhou & 52 & 52 & - & 42 & 42 & - & 28 & 28 & - \\
\hline Mianyang & 29 & - & 29 & 28 & - & 28 & 28 & - & 28 \\
\hline Deyang & 51 & - & 51 & 51 & - & 51 & 51 & - & 51 \\
\hline Total & 628 & 189 & 439 & 338 & 160 & 178 & 297 & 119 & 178 \\
\hline
\end{tabular}

Source: Survey results. 


\section{Table 1.2 A comparison of Phase I and Phase ll sample}

\begin{tabular}{lrlrrrrrrr}
\hline & \multicolumn{2}{c}{$\begin{array}{c}\text { Employees (persons) } \\
\text { Average Std. Dev. CV }\end{array}$} & \multicolumn{2}{c}{$\begin{array}{c}\text { Sales (mil. yuan) } \\
\text { Average Std. Dev. CV }\end{array}$} & \multicolumn{2}{c}{$\begin{array}{c}\text { Fixed capital (mil. yuan) } \\
\text { Average Std. Dev. CV }\end{array}$} \\
Phase I & 264.8 & 604.1 & 2.3 & 47.5 & 170.0 & 3.6 & 13.3 & 33.8 & 2.6 \\
Phase II & 91.3 & 277.2 & 3.0 & 12.1 & 35.2 & 2.9 & 6.2 & 29.5 & 4.8 \\
\hline
\end{tabular}

Note: $\mathrm{CV}^{1}$ stands for coefficient of variation (dispersion).

Source: Survey results.

Finally, two points relating to the sampling need to be mentioned. First, the inclusion of some recommended firms by local governments into the large sample that was selected in a statistically correct way might, to some degree, compromise the randomness of the total sample. Second, the second Stage sample collected through local government agencies might introduce some response bias, while resulting in a more representative sample (e.g. size of firms). These factors could have some implications for formal analysis of results.

One way to identify the effect of the loss of randomness is to carry out a test for sample biases with any problems being resolved by adjusting the sample weights accordingly. Formal tests for pooling the two samples can be carried out using multivariate regression models with dummy variables for Survey method, Survey location and other factors that might be thought relevant. Several testable hypotheses with respect to private enterprise development in China have been identified and tested, and the results are reported in the statistical appendix of this book. 


\section{Notes}

1. The study defines domestic private enterprises as all enterprises under the control of private domestic entrepreneurs including joint ventures and township and village enterprises (TVEs). However, due to the practical constraints on selecting firms for the Survey, only those firms which were formally registered as private enterprises are included in the sample. We rely on other sources of information including our own estimates to assess the relative importance of broadly defined private enterprise in the economy.

2. Most tables containing more aggregated pictures of private enterprises, such as their shares in total employment and output, are derived from official publications. Some, such as the relative importance of the private sector in total GDP, are estimated by the research team. Sources are specified with the tables.

3. After taking account of missing mail due mainly to changes of business addresses since registration, the rate of return could be well above 30 per cent.

4. The research team was faced with some choices in conducting the $\mathrm{CEO}$ interviews. Filling in the CEO questionnaires during interviews could secure a high return of the questionnaires. However, in so doing, less time would be devoted to the more open-ended questions and it was also likely that some insights that CEOs wanted to convey to the interviewers would be missed if both interviewers and CEOs strictly followed the questionnaires during interviews. On the other hand, by focusing on the more open-ended questions and not asking the CEOs to fill in the questionnaires at the time resulted in some missing questionnaires in the sample. This was because some CEOs failed to send the questionnaires back after interviews despite repeated phone calls by the research team urging them to do so.

5. See Section 3.1 for more detailed descriptions about the four sample cities.

6. 'Firms whose main business is not in the productive sectors (such as trading or real estate firms) will be replaced' (see the Information Note of the project).

7. In the Survey, it was difficult to implement this ownership strategy strictly due to the unavailability of the required database at local government agencies (also see footnote 8 ) and difficulties in identifying those firms which are not registered private firms but under the control of private domestic entrepreneurs. Single proprietors were excluded from the sampling. Later in the implementation stage, a few joint ventures and firms engaged in commerce and services were also Surveyed.

8. Most of the databases for registered private firms in these cities were constructed only recently. Some are still at a developmental stage and staff could not satisfy the requests put forward by the research team. For example, in the case of Beijing, the Bureau of Industry and Commerce Management had to rely on an external expert to extract the requested data from their system for the sampling. In the case of Wenzhou, the research team had to rely on registration records in written form for sampling since an electronic data system was not available. These practical difficulties affected, to some extent, the implementation of the stratified strategy of sampling.

9. The second phase of the Survey was prompted by the low return rate from the mail-out of the firm level questionnaire in the first phase (see Table 1.1). 


\section{2}

\section{Development of the role of private enterprise in China}

This chapter describes generally the development of the role of private enterprises in China prior to introducing the Survey results in later chapters.

\section{An historical perspective}

After the founding of the People's Republic in 1949, China quickly built up its state economy with support and aid from the Soviet Union. In 1949, private enterprises produced 63 per cent of the national industrial output; by 1952 , this percentage had declined to only 39 per cent. $^{1}$

During this early period, the government aimed to place the private sector under control of the plan system by means of 'state capitalism'. By 1952, 56 per cent of the private sector's industrial output was to or through the government.

Alongside 'state capitalism', some private firms were transformed into state-private cooperatives. In 1952, their output accounted for 5.7 per cent of the national total. In 1953, the Communist Party proposed a timetable in The General Guidance for the Transitional Period to complete the socialist transformation of private firms and individual handicrafts in 15 years. However, the socialist transformation process was later accelerated as a result of several factors.

In October 1953, the central government implemented the policy of tonggou tongxiao, or centralised purchases and centralised sales. This policy put the procurement from farmers and wholesale trade of grains, cotton, edible oil, and clothes under the control of the government. The objective of this policy was to provide stable and low-priced supplies of food and necessities to support China's heavy industry-oriented industrialisation. This policy enabled the government to control over 70 per cent of the total national wholesale volume by the end of 1953. At the same time, the government increased the share of government orders and purchases in private firms' output which also rose to 70 per cent. Since two thirds of the private firms produced light products, the 
tongguo tongxiao policy forced a large part of the private sector under the state's control and made it much easier for the state to carry out the socialist transformation of these firms.

Starting in 1952, China began to imitate the Soviet Union by implementing five-year plans. However, the plan only covered state-owned firms. As a result, there was imbalance between private and public supply and demand of many material supplies. This created an incentive for both state and private firms to accelerate transformation.

The strength of the cooperative movement in the countryside turned the political atmosphere against the existence of private ownership and operations even in the cities. The squeeze by the state caused the financial situation of private firms to deteriorate, and their workers' welfare declined. Encouraged by the cooperative movement of the peasants, workers from private firms also demanded transformation.

Finally, the good record of the first five-year plan period and weak resistance, and sometimes even enthusiastic response by private owners to the transformation reinforced the government's confidence in socialism and encouraged it to accelerate the socialist transformation.

The socialist transformation of private firms was rapidly completed in 1956. Private owners were assigned jobs in their own factories and allowed to receive a payment equal to 5 per cent of the value of their assets for 10 years (195665). In the meantime, the socialist transformation was implemented for individual handicraft shops. Individual craftsmen were re-organised into large cooperatives. During the Great Leap Forward in 1958-59, the majority of these cooperatives were transformed into local, state or commune factories.

By May 1959, amongst the 100 thousand cooperatives in the country, 37.8 per cent had been transferred into local state ownership, 35.3 per cent were absorbed into communes, 13.6 per cent were changed to wage-earning factories, and only 13.3 per cent were still run as cooperatives. Only after the catastrophe of the Great Leap Forward did the central government again recognise small individual businesses, including individual handicraft shops. Small individual businesses were totally shut down when the Cultural Revolution began in 1966, re-emerging only in the late 1970s. Private firms beyond the industrial enterprises were not allowed to operate until 1988.

The private economy operated underground during the period 1966 to 1979. This situation began to change when the rural reforms were initiated at the end of 1978. This change, like most of the recent reforms carried out in China, was not a result of conscious planning by the central government, but rather a spontaneous process triggered by a series of historical and current economic factors. 
In the countryside, the re-emergence of the private economy was a by-product of the rural institutional reform that restored family-based farming under a collective farmer contracting arrangement. This reform raised farmers' incentives and boosted agricultural output (Lin 1992). As a result, farm households accumulated a considerable amount of wealth in the process of fast output growth. On the other hand, following labour's intensive engagement in agricultural production at the outset of the reform, redundant rural labour began to emerge.

These two factors, income growth and surplus labour, worked together to redevelop private businesses in China's rural areas. In fact, the new farming system, although it did not acknowledge private freehold ownership of land, did recognise the legitimacy of private production. This sent a strong signal to farmers and encouraged them to engage in small non-agricultural activities. The Communist Party sanctioned farmers' initiatives by issuing a formal document in the Autumn of $1980 .^{2}$

In the cities, the resurgence of the private economy was brought about by the pressure on the government to solve the problem of unemployment amongst urban youth. In the late 1970s and early 1980s, millions of urban youths, who had been sent to the countryside during the Cultural Revolution, returned to the cities. The employment of these youths became a big burden to the government.

To solve the problem, the government encouraged the youths to engage in self-employment as well as to take up formal jobs assigned by the government. This policy was clearly stated in several government and party documents issued in 1981 that provided guidelines to solve the problems related to individual businesses such as land use, material supplies, business administration and ultimately, government recognition. ${ }^{3}$ In particular, a document issued jointly by the Central Committee of CCP and the State Council in October 1981 set the tone of the Party and the government toward individual economic units.

Another document issued by the State Council in July 1981 proposed concrete policies that awarded individual businesses some privileges, such as material supplies and land use, that were previously held by the state and collective economic units. In the same document, a new business category, geti gongshang hu, or single industrial and commercial proprietor, was defined. Getihu became a popular word in the 1980 s.

The Party and the government were cautious toward the development of getihu. In the July 1981 document, a cap of 5 was set on the number of employees a getihu could hire. In addition, individual economic units were only defined as supplementary to the state and collective economic units and allowed to develop only within certain limits. 
Nevertheless, getihu grew fast and gained momentum in 1988 when their numbers reached 23.1 million, or 10 per cent of the national total nonagricultural labour force (Figures 2.1 and 2.2). This rapid growth of getibu was made possible by several factors.

The urban reform undertaken in the 1980s created a dual-track price system that released a considerable amount of goods and services into the market. The biggest beneficiary of this reform was the rural population. For the first time in more than two decades, they began to have access to scarce industrial materials, although at higher prices than state enterprises. This helped the rural getibu to flourish.

The rural reform brought sizeable gains to the farmers and provided initial capital to the rural private economy. This initial source of capital was vital for the rural private economy since the state did not provide bank loans or credits to rural getihu. Not until these private businesses were well established and generated sizeable sales, income, employment and tax revenue, did the local governments provide funding to them.

Finally, the demand for standard consumer goods such as foods, garments and daily materials was high due to rising urban and rural purchasing power. On the other hand, after more than two decades of heavy industry-based development, the supply of consumer products was limited. As a result, a large market opportunity was created in which getihu could develop.

Figure 2.1 Workers in the private sector 1981-97 $(10,000)$

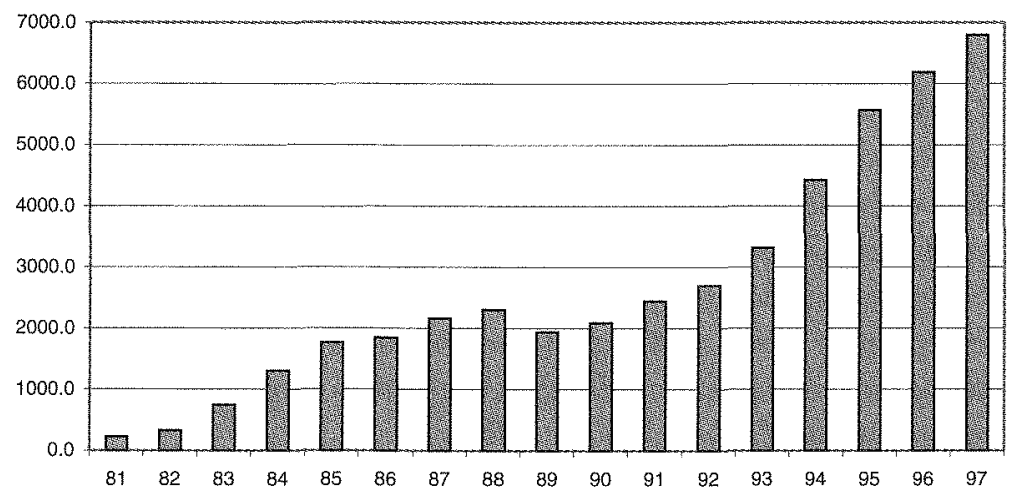

Notes: Before 1991, only getihu are included. Starting in 1991, both getihu and private firms are included.

Sources: Yearbook of China Industrial and Commerce Administrative Management, 199298, and China Statistical Yearbook, 1982-98. Gregory et al., 2000, IFC Report, Figure 1.2 p.1 
The growth of getihu in the early 1980s laid a solid foundation for less constrained private firms to enter the scene. In June 1988, a government document Tentative Stipulations on Private Enterprises (TSPE) was issued to govern the registration and management of private firms. ${ }^{4}$ In this document, a private firm was defined as 'a for-profit organisation that is owned by individuals and employs more than 8 people'. ${ }^{5}$ Firms that hire 8 or fewer people, could still be registered as getibu. ${ }^{6}$ This seemingly arbitrary distinction was made based on an example Marx used in Das Kapital with more than 8 people to illustrate the capitalist production process. It was therefore thought that hiring more than 8 people was a sign of exploitation while hiring less people was not.

The TSPE defined three types of private firms: sole ownership, partnership, and limited liability incorporation. For the first two types of firms, the TSPE still provides the standard government regulations for their registration. For the last type of firm, the Law of Corporation replaces the Stipulations to regulate it. A new law governing firms of partnership is being enacted by the People's Congress. A law governing sole ownership enterprises has been implemented

\section{Figure 2.2 Share of employment in private sector in national total 1981-97 (\%)*}

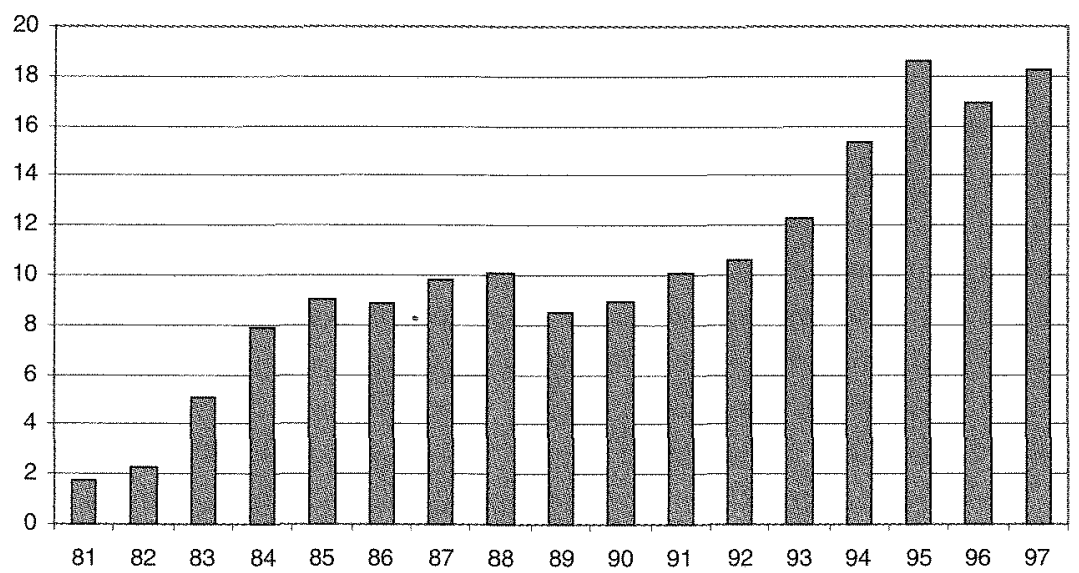

Note: *Percentage of private employment in the national non-farm labour force. Because of the new categorisation used after 1995, the later has been increased ar tificially since 1996 and shares of private sector in 1996 and 1997 were not comparable with those of the earlier years. Before 1991, only getihu are included; starting in 1991, both getihu and private firms are included.

Sources: Yearbook of China Industrial and Commerce Administrative Management, 1992-98, and China Statistical Yearbook, 1982-98. Gregory et al., 2000, IFC Report, , Figure 2.5 p.17 
from 1 January 2000. There is more detailed discussion on firm registration in Chapter 10.

Although the existence of private firms was not formally acknowledged and sanctioned by the government until 1988 when the TSPE was issued, many getih $u$ were qualified as private firms in terms of the number of employees even before 1988. According to a 300-village survey conducted by a research branch of the State Council in 1987, 0.2 per cent of farm households hired more than 8 people in 1986. Taking the survey as a representative sample, it was estimated that at the end of 1988, there were 500 thousand getihu in the country that could be called private firms (Zhang and Liu 1995:55).

In addition, many firms were registered as having collective ownership when they were actually privately owned. Such a firm was called a 'red hat' firm: the private owner put on a collective ownership hat to evade the government prohibition of private firms, ideological harassment and to qualify for favourable regulatory treatment. This kind of firm continued to exist even after the TSPE was issued in 1988. Although no national figure for this type of firm is available, it was found by our research team that almost all the collective firms at the village level in Shunde were red hat firms before the privatisation program took place in 1992. The 'red hat' phenomenon was important in all cities covered by the survey in 1999, and most important in Beijing and the Sichuan provinces where the acceptability of private ownership was still being established.

Finally, many collective firms were rented out to private operation. In 1984, the percentage of such firms in the total number of collective firms was, respectively, 19 per cent, 30 per cent, 40 per cent and 50 per cent in Hebei, Tianjin, Liaoning, and Ningxia (Zhang and Liu 1995:29). Private entrepreneurs operated such firms as if they were their own, paying the collective a fixed rent and in many cases accumulating considerable capital assets. As a result, the share of the collective assets diminished and the firm was gradually transformed into a solely privately-owned firm. At the end of 1989 , the number of registered private firms reached 90,600 in total.

The development of the private sector suffered a setback with the sudden shift in the political atmosphere after the 1989 fracture in Beijing. The number of registered getihu declined from 23.1 million at the end of 1988 to 19.4 million at the end of 1989 (Figure 2.1). The number of registered private firms declined from 90,600 at the end of 1989 to 88,000 in June 1990. Amongst firms being closed down, a considerable number were transferred into collectives or reduced their number of employees to under 8 people. For example, in a survey conducted on 286 private firms closed in the period of January to April 1991, 22.7 per cent were transferred to collective ownership, and 20.3 per cent reduced their number of employees to under 8 (Zhang and Liu 1995:50-1). 
The setback was not fully reversed until Deng Xiaoping in 1992 paid his famous visit to the south and called for continuing the reform effort. At the end of 1992, the number of registered getihu and private firms reached 27 million and 140 thousand, respectively. The period 1992 to 1994 saw the most rapid increase in the number of private firms, employment and output in recent times (Table 2.2). Attitudes toward private firms were changed as a result of Deng Xiaoping's call for further market-oriented reforms, providing private entrepreneurs with a supportive social and psychological environment. In addition, the national economy was in a new round of expansion providing rapidly expanding market opportunities for privately produced products.

The development of the private sector was enhanced by the privatisation programs starting in various parts of the country soon after Deng's visit to the south. The private sector has served as an appropriate model for the SOEs by demonstrating attainable efficiencies in operations. Examples of this will be given in the next section.

The Fifteenth Congress of the CCP held at the end of 1997 elevated the role of the private sector to one of parity with the state sector. Subsequently, this new move was recognised in China's Constitution by a new amendment in the spring of 1999. While it is a legal milestone, the amendment was an endorsement of what had already happened, rather than a new development. The amendment did not include a clause that provided private property with full protection of rights.

The above review has shown that the rate of development of the private sector in China since 1949 has shifted from being governed primarily by government ideology and associated policies, to depending on domestic and international macroeconomic conditions and the regulatory framework. This change started with Deng Xiaoping's visit to the south. With the constitutional amendment in place, the de-linking of the private sector and government ideology can be expected to continue in the future.

\section{Contributions of the private sector to the national economy}

The private sector has been playing an increasingly important role in China's national economy as shown by rapid increases in employment and output shares of private sector in the national total (Figures 2.2 and 2.4). Before 1985, the share of private sector industrial output in the national total was negligible although it had already accounted for around 2 per cent of the national nonagricultural labour force in 1981. By 1997, its share in national industrial employment exceeded 18 per cent. In 1985, its share of national industrial output reached nearly 2 per cent. By 1993 , that figure had climbed to 12.2 per cent. In 1997, it reached 34.3 per cent (Figure 2.4). 
In absolute terms, private sector industrial output has experienced substantial and rapid growth in the last two decades to reach 3.8 trillion yuan in 1997 (Figure 2.3). The expansion of employment experienced a major down turn in the period 1989 to 1991, but has since grown rapidly. By 1997, the total number of workers reached 67.9 million (Figure 2.1).

Including agriculture in GDP but not in the private sector, the private sector's share in GDP reached 33 per cent in 1998 (Figure 2.5 and Table 2.1). In 1998, the private sector was still smaller than the state sector whose share of national GDP was 37 per cent. If agriculture-a sector comprises mainly individual farmers - is regarded as private as seems more appropriate, the share of the private sector rises to 50 per cent (Figure 2.6). ${ }^{8}$ The private sector and collectives together contributed a non-state sector share of 62 per cent in $1998 .{ }^{9}$

The fast growth of the private sector in the 1990 s was mainly within private firms, as distinct from non-incorporated enterprises. In 1991, the output share of firms in the private sector's total was only about 17 per cent. In 1997, it reached 47 per cent. In the period 1991 to 1997, for which data are available, the annual growth rates for the number of private firms, employment, and output were 46 per cent, 41 per cent and 71 per cent, respectively (Table 2.2). According to the statistics provided by SETC, by 1998, the total number of registered private firms was 1.2 million, employing 17.1 million employees with total registered capital of 719.8 billion yuan, total output value of 585 billion yuan and total sales of 305.9 billion yuan.

It is noteworthy that the private sector's share of output and employment has been achieved using far fewer resources than other sectors. In the period 1991 to 1997 , the share of the private sector's investment in the national total was in the range of 15 per cent to 27 per cent. In addition, the sector took a negligible portion of formal bank loans: at the highest, only 0.87 per cent of formal bank loans in 1997. The disproportion between its contributions to output and employment and its utilisation of capital and other non-labour inputs is a major feature of China's private sector development in the 1990s.

Statistics released by the State Bureau of Industry and Commerce Management $(\mathrm{BICM})^{10}$ show that by June 1999 the total number of private firms in China reached 1.3 million, with registered capital of 817.7 billion yuan, and employing 17.8 million workers. All three indicators increased by about 25 per cent over 1998. Private enterprises have also been making rapid progress in their transformation towards a modern enterprise system. For example, by June 1999, there were altogether 700,000 private corporations with limited liability, an increase of 33.7 per cent over the same period in 1998, accounting for about 55 per cent of total private enterprise in China.

The rapid development of the private sector in the 1990s has been a major catalyst for SOE reform. A major SOE reform in the 1990s was the privatisation of small SOEs. Currently, about 80 per cent of firms that had been owned by 


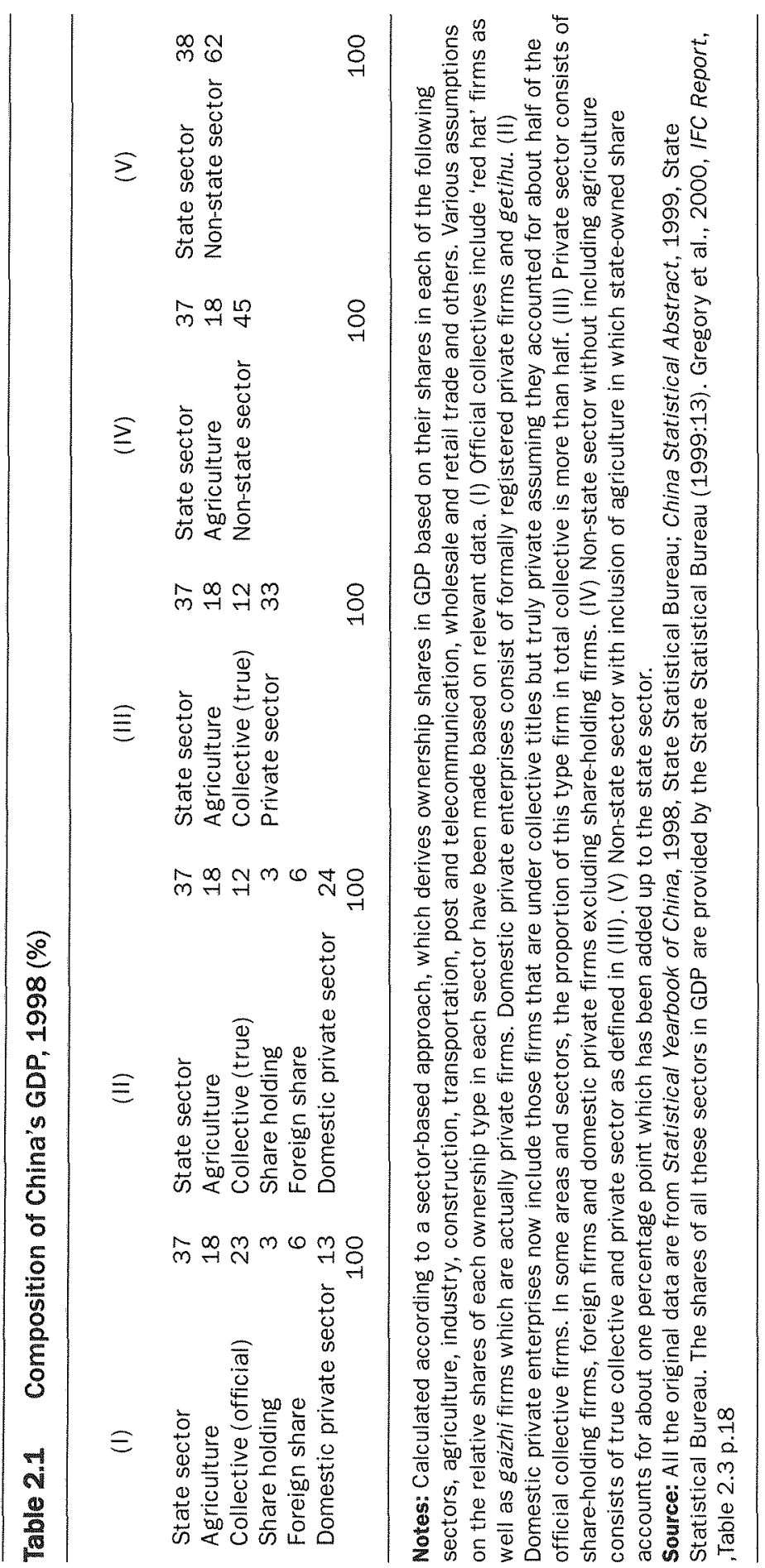


Figure 2.3 Industrial output of private sector 1980-97 (billion yuan: 1995 constant prices)

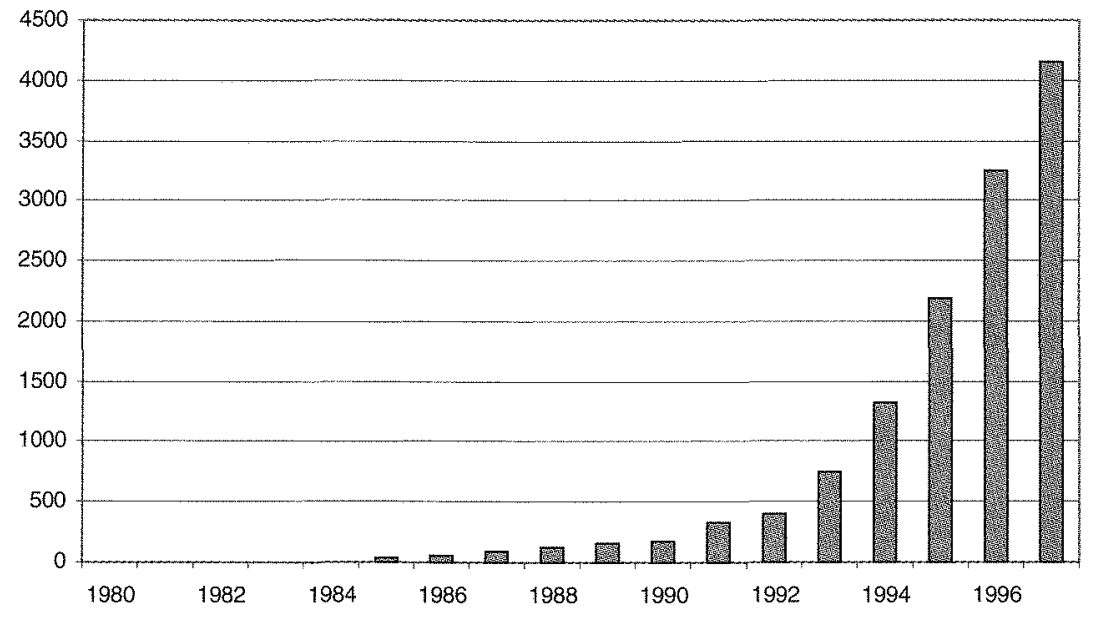

Notes: Data on private firms are added beginning in 1991.

Sources: Yearbook of China Industrial and Commerce Administrative Management, 1992-98, and China Statistical Yearbook, 1982-98, State Statistical Bureau, Beijing. Gregory et al., 2000, IFC Report, Figure 1.3, p.2.

Figure 2.4 Share of private sector industrial output in national total 1980-97 (\%)

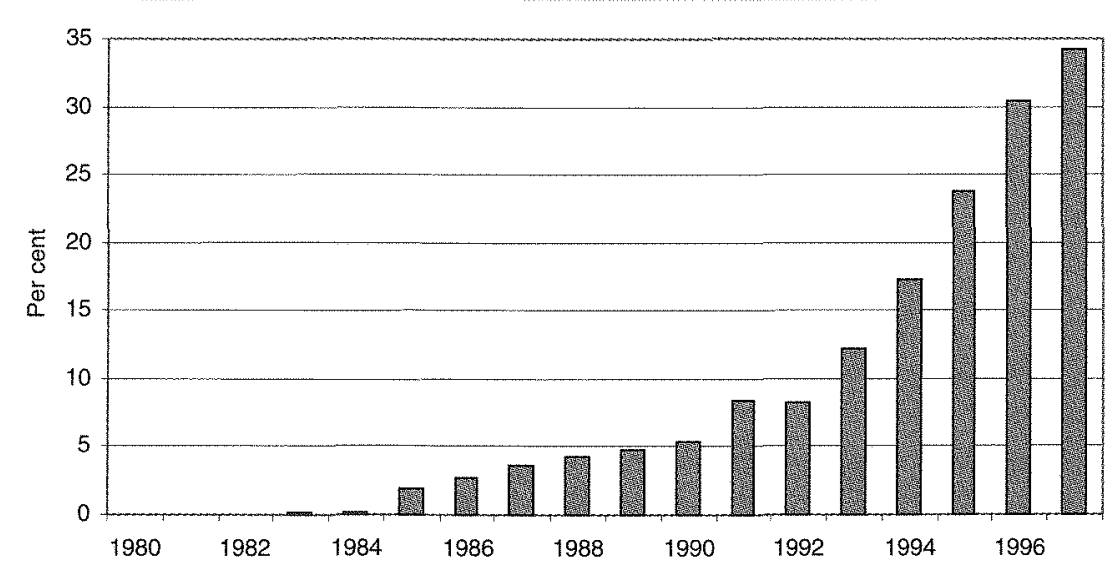

Notes: Data on private firms are added starting in 1991.

Sources: Yearbook of China Industrial and Commerce Administrative Management, 1992-98, and China Statistical Yearbook, 1982-98, State Statistical Bureau, Beijing. Gregory et al., 2000, IFC Report, Figure 2.4, p.17. 


\section{Figure 2.5 Ownership shares in China's GDP: 1998 (\%)}

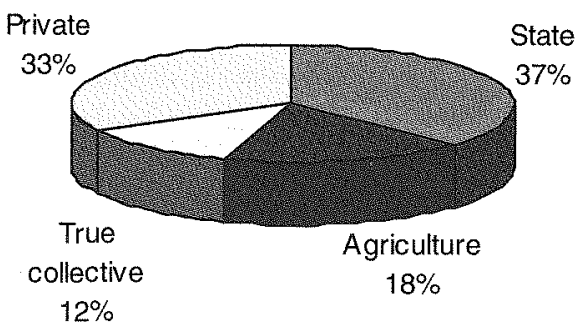

Source: Table 2.1 (III). Gregory et al., 2000, IFC Report, Table 2.3, p.18.

\section{Figure 2.6 Private sector including agriculture in total GDP: 1998}

(\%)

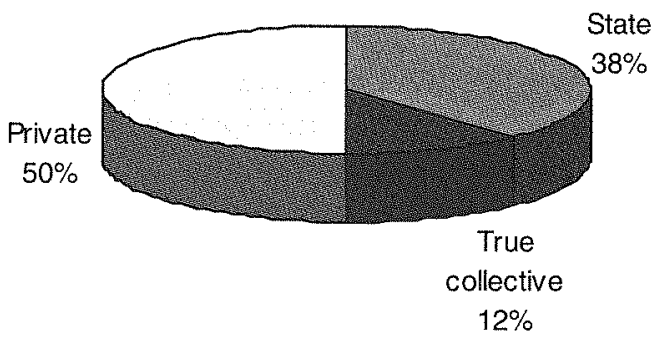

Source: Table 2.1 (III) assuming one percentage point of state-owned agriculture. Gregory et al., 2000, IFC Report, Table 2.3, p.18.

\section{Table 2.2 Private firm development since 1991}

\begin{tabular}{llccccc}
\hline & \multicolumn{3}{c}{ Firms } & \multicolumn{2}{c}{ Workforce } & \multicolumn{2}{c}{ Output* } \\
Year & $\begin{array}{c}\text { Number } \\
\text { Growth }\end{array}$ & \multicolumn{2}{c}{$\begin{array}{c}\text { Number } \\
\text { Growth }\end{array}$} & \multicolumn{2}{c}{ Value } & Growth \\
& $(1,000)$ & $(\%)$ & $(1,000)$ & $(\%)$ & (billion yuan) & $(\%)$ \\
1991 & 107.8 & n.a. & 1839.0 & n.a. & 93.7 & n.a. \\
1992 & 139.6 & 29.5 & 2318.4 & 26.1 & 116.0 & 23.8 \\
1993 & 237.9 & 70.4 & 3726.3 & 60.7 & 260.1 & 124.2 \\
1994 & 432.2 & 81.7 & 6483.4 & 74.0 & 551.7 & 112.1 \\
1995 & 654.5 & 51.4 & 9559.7 & 47.4 & $1,005.3$ & 82.2 \\
1996 & 819.3 & 25.2 & 11711.3 & 22.5 & $1,592.3$ & 58.4 \\
1997 & 960.7 & 17.3 & 13492.6 & 15.2 & $1,983.7$ & 24.6 \\
Average & & 45.9 & & 41.0 & & 70.9 \\
\hline
\end{tabular}

Note:*In 1995 constant prices. n.a. = not available as this is the starting year. Sources: Yearbook of China Industrial and Commerce Administrative Management, 1992-98; China Statistical Yearbook, 1992-98, State Statistical Bureau, Beijing. Gregory et al., 2000, IFC Report, Table 2.1, p.11. 
governments at the county or lower administrative units have been privatised. By any standard, this is a major transformation. It has totally changed China's economic makeup by bringing private ownership to the vast majority of firms and workforce in the country. As in any other country, small firms account for the vast majority of firms in China. There is no doubt that the record of the private sector's performance has been a major catalyst for this great transformation.

The privatisation programs were initiated at the local level. The most important impetus for local privatisation was the large amount of debt accumulated in the state sector. This was a more pressing problem in small cities because of the smaller size of their economies. For example, in Zhucheng city, Shandong province, amongst the 150 city government-owned enterprises, 103 were making losses, and the total amount of loss was 147 million, equivalent to the city government's revenue over 1.5 years. Shunde met the same problem when it first started its privatisation program in 1992. The solution reached at the local level was to privatise small firms, but the measures adopted in Shunde and Zhucheng were a more radical selling off of almost all its state and collective firms (Box 2.1).

In 1995, the central government, after several rounds of investigation and discussion, formed a policy called 'zhuada fangxiao' (keep the large ones and let go the smaller ones). The policy allowed the state to focus on retention and improvement of performance in 500 to 1000 large state firms and allowed smaller firms to be leased or sold. ${ }^{11}$ The government had good reason for this policy. In 1997, the 500 largest state firms had 37 per cent of the assets held by state industrial firms, contributed 46 per cent of the tax collected from all state firms, and 63 per cent of total profits in the state sector. The government believes that control of the (500) largest firms means it has control of the larger and better chunk of the state economy. By contrast, smaller firms owned by local governments performed even worse than those owned by the central government. In 1995, 24.3 per cent of the centrally owned firms were in the red, compared with 72.5 per cent of locally owned firms.

From the 'let go the smaller ones' part of the policy came a word 'gaizhi', meaning, 'changing the ownership structure'. Starting in 1994, gaizhi began to spread to the whole country. The content of gaizhi included contracting and leasing, the two methods used previously, as well as new methods of selling the firm or transforming it into an employee-held company or cooperative. Therefore, gaizhi did not necessarily imply privatisation. Yet the government was determined to get rid of the 'red hat' firms. In March 1998, it issued a directive requiring all red hat firms to 'take off the hat', that is, to show their private ownership, by November 1998.

Not all the localities had been fully prepared for gaizhi. Many firms changed their names, but nothing else substantial (see Box 2.2 for a description of gaizhi in Sichuan province). This is particularly true for firms taking up the 
ownership category of employee shareholding. These firms are still regarded as collective firms, and local governments still interfere in their operations. This is a problem in the transformation of local governments' functions. Yao and Zhaohua (2000) have shown that privatisation is not sufficient to improve economic efficiency if the role of the government does not change.

In particular, if the government tolerates its employees' rent-seeking behaviour in relation to privatised firms, the contributions of private entrepreneurs will be held back. In this regard, the municipal government of Shunde has performed well. In the course of its privatisation program, the Shunde government undertook a radical reform by cutting one third of its employees and 40 per cent of its functional units. This reform has served as a signal to the private sector that the government is committed to curbing rentseeking behaviour and micro-level interference more generally. To a large extent, the smooth and successful transformation in the city should be attributed to government reform.

\section{Evolution of private firms' ownership}

Before 1988, private firms with more than 5 employees were not officially acknowledged. Private entrepreneurs who wanted to expand their operations to more than 5 people had to find a disguise although quite a few dared to ignore government restrictions and operated without any disguise. This created many 'red hat' firms that were registered as collectives, but were actually run by private entrepreneurs. This was more common in the countryside.

The extraordinary performance of China's rural industrialization was attributed by some observers to the combination of private entrepreneurship and collective ownership. These authors' main argument was that the combination was a second best response to imperfections in China's market and policy environments (for example Che and Yingyi 1998; Li 1996, 1997).

While the combination of private entrepreneurship and public ownership was one solution to market and policy failures, the argument missed the point that many private entrepreneurs put on the 'red hat' just to evade ideological bias and government regulations. This tendency was clearest in the period 1989--91. From the perspective of the local government, in many cases it suffered rather than benefited from the presence of a 'red hat' firm.

In Shunde, for example, the most important reason for privatisation by the local government was to get rid of the burden of 'red hat' and other government-owned firms. A 'red hat' firm created an asymmetry to an entrepreneur's incentive. If the firm made a profit, it was appropriated privately. If it made a loss, it was shouldered by the government. As a result, a considerable amount of debt was accumulated by village and township governments. Government officials in Shunde called this 'bleeding', and the privatisation program the 'stopping bleeding project'. 


\section{Box 2.1 Shunde's privatisation}

When Shunde first began its privatisation program in 1992, it tried to maintain a form of collective ownership and adopted employee shareholding as the only form of privatisation. However, several problems were encountered with this form of privatisation. Employees might not purchase shares either because they did not have enough money or faith in the factory's future. The manager in an employee-held firm still played the role of an agent, and state and collective firms still faced a monitoring problem. Free-riding was still a problem as workers' dividends from shares were independent of their work contributions. Uniform shareholding did not help establish authority within a firm. Therefore, Shunde shifted to other forms of privatisation after this initial experience. These forms included listing in the stock market, management leasing and management buy-out (MBO).

Because China has a policy severely restricting the number of firms to be listed in its two stock markets in Shanghai and Shenzhen (usually in the form of quotas to each province), only two Shunde firms, MD and Kelong, have been listed in the stock market (Shenzhen). To get around the government restriction, some firms were sold or partly sold to a listed firm in another city, so their shares could be listed in the stock market. This form of privatisation is called 'to borrow the shell for the egg'.

Management leasing was used for firms that had a large amount of net assets or in circumstances where management could not mobilise enough funds to buy the firm. In this form of privatisation, management purchased the equipment and leased the land and buildings from the local government that previously owned the firm. This was used more often in retail and wholesale businesses.

MBO was the most important means of privatisation. Many firms that were initially privatised by employee shareholding were transformed into MBO through the concentration of shares in the hands of management. This has been encouraged by the Shunde government.

Before it was sold to management, a firm's assets and debts were valued by an outside accounting firm, usually from Guangzhou, the provincial capital. It is noteworthy that land was included in the evaluation. When management bought the firm, it purchased the use rights of the land occupied by the firm. The term of the use rights ranged from 50 years to 70 years, and the price of land ranged from the current 30,000 yuan/mu (one mu $=1 / 15$ hectares) to 50,000 yuan $/ \mathrm{mu}$ in the mid $1990 \mathrm{~s}$. The inclusion of land in the deal has a significant implication for a firm in terms of its ability to provide collateral for loans. To protect workers' employment, no more than 5 per cent of the workforce could be fired in three years. Competitive bidding was allowed, but the incumbent had priority if it had the same qualifications as its competitors. As a result, it was usually the case that the firm was purchased by the original management. To handle the problems emerging in the transitional period (including debt issues and ownership transfers), the government usually asked management to register a new firm that owned the old firm together with the government. After the transition was finished, the management could decide which name it would use for its firm.

For a firm with positive net assets, the top management was asked to pay for the price of the net assets and shoulder the firm's debts. The payment could be made within five years. For some firms that had large net assets, the local government retained a large proportion of the shares. For a firm with a net debt, the local government that previously owned the firm would take over the net debt. The management had to purchase 15 per cent of the firm's gross assets with the payment being made within five years. However, its share of the debts was also reduced by the same amount, and the local government took the reduced amount. For example, for a firm with 20 million gross assets and 22 million debts, the local government would first take over the 2 million net debts, and the management would pay 3 million cash within five years to buy 15 per cent of the 20 million assets. The firm's net assets were kept at zero when it was handed over to management, and in the long run, the management would get the firm free of debt, although it had to pay a considerable amount of cash in a short period. 


\section{Box 2.2 Gaizhi in Sichuan province}

Sichuan is a province dominated by small firms. In 1994, the provincial government began to implement gaizhi, starting from county-owned enterprises. By the end of 1998 , the province completed gaizhi for 68.6 per cent of the 42,681 firms planned to be transformed. Among those transformed, 35.1 per cent became employee-owned companies, 11 per cent employee-owned cooperatives, 14.3 per cent were sold out, 7 per cent were contracted out to individuals, 8.5 per cent were leased out, 7 per cent entered bankruptcy, and 5 per cent were absorbed by other firms. There were regional differences. In Yibin county, gaizhi was predominantly employee shareholding. In lintang county, selling was more common. In Shehong county, mergers were encouraged.

Since gaizhi was enforced by the provincial government, some local governments did not have sufficient preparation for it. One problem was that local officials treated gaizhi as an administrative task, putting emphasis only on the speed of gaizhi, but not its real content. The consequence was that many firms changed their names, but not their management. In many cases, managers were still appointed by local governments. In addition, the provincial government did not have a good solution to the debts accumulated by firms, hindering the effectiveness of gaizhi. Neither did it have a solution to the unemployment problem accompanying gaizhi. In short shortshort, the government did not provide proper institutional capital to support gaizhi.

Before 1988, the existence of 'red hat' firms was more a result of the ideological restriction and government prohibition than a rational choice made jointly by private entrepreneurs and the local government. The influence of ideology was never more obvious then in the period 1989-91 when many private owners transferred their factories to collective ownership under pressure of the conservative ideology prevailing in that period. After Deng Xiaoping paid his visit to the south in the spring of 1992, however, private firms flourished again, showing yet another example of the consequences of ideological change in China.

Currently, three kinds of ownership are defined for private firms by the Chinese laws governing firm registration. They are sole ownership, partnership, and a limited liability company. ${ }^{12}$ Owners of the first two kinds of firms accept unlimited liability, and the owners of the last only accept limited liability in their firms' fortunes. Table 2.3 shows the ownership structure of the private firms in 1991, 1994 and 1997. From 1991 to 1997, the number of private firms increased 7.9 times. The number of limited liability companies grew most rapidly reaching 65.3 times. Sole ownership showed the second largest increase, 5.4 times. Partnership was the least, at 2.2 times during the period.

As a result, the relative importance of the three kinds of firms changed dramatically. Limited liability companies had the smallest share in 1991, but became the predominant form of ownership in 1997. A limited liability company offers a firm several advantages to owners, including protection of personal wealth, a better firm image, and better internal governance. 
In terms of registered capital, limited liability companies are the largest, partnerships are second, and sole ownership firms the smallest (Table 2.4). The sizes of all three kinds of firms increased from 1991 to 1994 , but from 1994 to 1997 , the sizes of partnership and sole ownership firms declined significantly while those of limited liability firms remained almost unchanged. These trends owed something to China's macroeconomic fluctuations in general and government anti-inflationary measures in particular. They also reflect influence from the rapid increase in numbers of new private firms, which tend to be small at the beginning.

\section{Sectoral and regional distributions of private firms}

The number and growth rates of private enterprises vary across sectors of the economy. By the first half of 1999 , there were 30,000 private firms in primary industry (mainly agriculture), an increase of 20 per cent from the end of 1998. There were 530,000 firms in secondary industry (manufacturing), up about 5 per cent from half a year earlier.

The majority of private firms are in tertiary industry (services). The number of firms in this sector had reached 722,000 by June 1999 , accounting for about 56 per cent of the total number of private firms in China. According to statistics released by BICM in late 1999, private enterprises hired a total of 8.0 million workers, accounting for about 45 per cent of total employment in the tertiary industry. 'Their registered capital reached 504.8 billion yuan, accounting for about 62 per cent of the total registered capital in the same industry.

Tables 2.5 and 2.6 show the sectoral distribution of private firms in terms of employment and output from 1992-97. Industry is the largest sector, occupying more than half of the employment and output in the private sector in 1997. Trading is the second largest sector, accounting for more than 30 per cent of employment and output. From 1992 to 1997, the shares of industrial employment and output declined by about 10 percentage points. During the same period, the shares of trading companies' employment and output increased by 15 and 7 percentage points. The shares of other sectors didn't have such significant changes.

Table 2.7 provides information on the regional distribution of private firms. In the table, the provincial units are divided into three groups, coast, central, and west. There is a ladder of development of private enterprise (in terms of numbers of private firms) coming down from the coast to the west. In 1992, the numbers of firms in the west, central and coast had a ratio of $21: 26: 100$; in 1997, the ratio became 23:34:100.

In terms of employment, the central and west caught up even faster. In 1992, the ratio among the three regions was 22:26:100; in 1997, it had become 25:39:100. In terms of both the numbers of firms and employment, the central provinces caught up with the coastal provinces faster than western provinces. 


\section{Table 2.3 Ownership structure of private firms}

\begin{tabular}{|c|c|c|c|c|c|c|}
\hline & \multicolumn{2}{|c|}{1991} & \multicolumn{2}{|c|}{1994} & \multicolumn{2}{|c|}{1997} \\
\hline & Firms & Share (\%) & Firms & Share (\%) & Firms & Share (\%) \\
\hline Sole ownership & 60,613 & 56.2 & 100,621 & 47.6 & 387,534 & 40.3 \\
\hline Partnership & 40,552 & 37.6 & 37,532 & 17.8 & 130,668 & 13.6 \\
\hline Limited liability & 6,678 & 6.2 & 103,235 & 48.8 & 442,554 & 46.1 \\
\hline Total & 107,843 & 100.0 & 211,388 & 100.0 & 960,726 & 100.0 \\
\hline
\end{tabular}

Sources: Yearbook of China Industrial and Commerce Administrative Management, 1992-98.

\section{Table 2.4 Capital size distribution of private firms (1,000 yuan)}

\begin{tabular}{lrrr}
\hline & 1991 & 1994 & 1997 \\
& & & \\
Sole ownership & 87.0 & 335.5 & 199.9 \\
Partnership & 100.5 & 474.3 & 276.2 \\
Limited liability & 445.1 & 903.1 & 904.8 \\
Total & 11.4 & 684.9 & 535.0 \\
\hline
\end{tabular}

Sources: Yearbook of China Industrial and Commerce Administrative Management, 1992-98.

\section{Table 2.5 Sectoral distribution of private firms: workers}

\begin{tabular}{|c|c|c|c|c|c|c|c|c|}
\hline \multirow[b]{2}{*}{ Sector } & \multicolumn{2}{|c|}{1992} & \multicolumn{2}{|c|}{1993} & \multicolumn{2}{|c|}{1996} & \multicolumn{2}{|c|}{1997} \\
\hline & $\begin{array}{c}\text { Workers } \\
(' 000)\end{array}$ & $\begin{array}{c}\text { Ratio } \\
(\%)\end{array}$ & $\begin{array}{l}\text { Workers } \\
\text { ('000) }\end{array}$ & $\begin{array}{c}\text { Ratio } \\
(\%)\end{array}$ & $\begin{array}{c}\text { Workers } \\
(\mathrm{O} 00)\end{array}$ & $\begin{array}{c}\text { Ratio } \\
(\%)\end{array}$ & $\begin{array}{c}\text { Workers } \\
\text { ('OOO) }\end{array}$ & $\begin{array}{c}\text { Ratio } \\
(\%)\end{array}$ \\
\hline Agriculture & n.a. & n.a. & n.a. & n.a. & 166.4 & 1.4 & 237.3 & 1.8 \\
\hline Industry & 1611.5 & 69.5 & 2296.6 & 61.7 & 6396.4 & 54.6 & 7000.8 & 51.9 \\
\hline Construction & 102.0 & 4.4 & 156.1 & 4.2 & 425.1 & 3.7 & 475.2 & 3.5 \\
\hline Transportation & 34.8 & 1.5 & 49.7 & 1.3 & 117.7 & 1.0 & 141.3 & 1.0 \\
\hline Trading & 389.5 & 16.8 & 845.8 & 22.7 & 3545.1 & 30.3 & 4362.3 & 32.3 \\
\hline Catering services & s 40.7 & 1.7 & 65.7 & 1.7 & 211.1 & 1.8 & 249.8 & 1.9 \\
\hline Social services & 51.9 & 2.3 & 144.5 & 3.9 & 590.4 & 5.0 & 729.6 & 5.4 \\
\hline Repairing services & is 29.7 & 1.3 & 38.7 & 1.0 & 44.6 & 0.4 & 4.38 & 0.3 \\
\hline Others & 58.3 & 2.5 & 129.2 & 3.5 & 214.6 & 1.8 & 252.5 & 1.9 \\
\hline Total & 2318.4 & 100 & 3726.3 & 100 & 11711.3 & 100 & 13492.6 & 100 \\
\hline
\end{tabular}

Source: Yearbook of China Industrial and Commerce Administrative Management, 1992-98. 


\section{Table 2.6 Sectoral distribution of private firms: output}

\begin{tabular}{lrrrrrrrrr} 
& \multicolumn{2}{c}{1992} & \multicolumn{2}{c}{1993} & \multicolumn{2}{c}{1996} & \multicolumn{2}{c}{1997} \\
Sector & Output & $\begin{array}{c}\text { Ratio } \\
(\%)\end{array}$ & Output & $\begin{array}{r}\text { Ratio } \\
(\%)\end{array}$ & Output & $\begin{array}{c}\text { Ratio } \\
(\%)\end{array}$ & Output & $\begin{array}{c}\text { Ratio } \\
(\%)\end{array}$ \\
Agriculture & n.a. & n.a. & n.a. & n.a. & 10.37 & 1.88 & 14.69 & 2.09 \\
Industry & 18.94 & 59.44 & 38.00 & 51.99 & 294.73 & 53.56 & 355.94 & 50.71 \\
Construction & 0.86 & 2.69 & 2.60 & 3.56 & 20.54 & 3.73 & 25.94 & 3.70 \\
Transportation & 0.71 & 2.23 & 1.57 & 2.15 & 8.44 & 1.53 & 10.40 & 1.48 \\
Trading & 8.83 & 27.71 & 24.89 & 34.05 & 181.11 & 32.91 & 243.36 & 34.67 \\
Catering services & 0.86 & 2.70 & 1.59 & 2.18 & 9.77 & 1.77 & 12.28 & 1.75 \\
Social services & 0.57 & 1.77 & 2.00 & 2.73 & 18.30 & 3.33 & 26.81 & 3.82 \\
Repairing services & 0.43 & 1.34 & 0.55 & 0.75 & 1.54 & 0.28 & 1.78 & 0.25 \\
Others & 0.68 & 2.13 & 1.90 & 2.60 & 5.52 & 1.00 & 10.71 & 1.53 \\
Total & 31.87 & 100 & 73.10 & 100 & 550.33 & 100 & 701.92 & 100 \\
\hline
\end{tabular}

n.a. $=$ not available

Notes: Billion yuan in current prices.

Sources: Yearbook of China Industrial and Commerce Administrative Management, 1992-98.

\section{Table 2.7 Regional distribution of private firms: number of firms and workers ('O00)}

\begin{tabular}{lrrrrrr}
\hline & \multicolumn{2}{c}{ Coast } & \multicolumn{2}{c}{ Central } & \multicolumn{2}{c}{ West } \\
Year & Firms & Workers & \multicolumn{1}{c}{ Firms } & Workers & Firms & Workers \\
1992 & 95.4 & 1754.5 & 24.5 & 453.4 & 19.7 & 380.5 \\
1993 & 159.3 & 2351.3 & 44.6 & 768.9 & 34.1 & 600.6 \\
1996 & 529.2 & 7232.8 & 178.6 & 2741.2 & 111.4 & 1737.4 \\
1997 & 610.1 & 8235.5 & 211.1 & 3189.7 & 139.5 & 2067.4 \\
\hline
\end{tabular}

Notes: Coast: Liaoning, Hebel, Beijing, Tianjin, Shandong, Jiangsu, Shanghai, Zhejiang, Fujian, Guangdong. Central: Helongjiang, Jilin, Shanxi, Henan, Hubei, Anhui, Jiangxi, Hunan, Hainan. West: Inner Mongolia, Shannxi, Ninxia, Gansu, Qinghai, Xinjiang, Tibet, Sichuan, Guizhou, Yunnan, Guangxi.

Source: Yearbook of China Industrial and Commerce Administrative Management, 1992-98. Gregory et al., 2000, IFC Report, Table 2.2, p.12.

The Chinese government is making efforts to shift its investment to the central and western provinces. While this project will speed up the development of the inland provinces, it is questionable whether it is optimal for the whole country. The regional disparities in economic growth may simply reflect the different capacity for economic growth of different regions (Lin and Yao 1998). Over-investment in the inland provinces may well conflict with the distribution of opportunities for economic growth and be economically 
inefficient. More market-oriented policies may generate better outcomes for people currently resident in western provinces. For example, improved education to facilitate the migration of inland people to higher income employment in the coastal provinces may achieve more efficiently the objective of the government, to increase the income of people living in the inland provinces. The alternative strategy would also help the development of the coastal provinces.

\section{Notes}

1. All the figures in the $1950 \mathrm{~s}$, if not otherwise indicated, are from Chapters 17 and 18 in Bo (1991).

2. Directives on Several Issues of the Agricultural Production Responsibility System, the Central Committee of CCP, 27 September 1980.

3. Directives on Issues Related to Land Used by Urban Collective and Individual Economy, Bureau of Labor, Bureau of Urban Construction, Ministry of Public Security, and Bureau of Industry and Commerce Management, 6 May 1981; Directives on Issues of Material Supplies to Urban Individual Businesses, Bureau of Industry and Commerce Management, Ministry of Commerce, Ministry of Grains, National Cooperative of Supply and Sales, Bureau of Materials, and Bureau of Labor, 22 June 1981; Policies on Urban Nonagricultural Individual Business, the State Council, 7 July 1981; and Several Directives on How to Use New Channels and New Methods to Solve Urban Employment, the Central Committee of CCP and the State Council, 17 October 1981.

4. The State Council, 15 June 1988.

5. Tentative Stipulations on Private Enterprises, Article 2.

6. We will discuss the implications of this distinction in Chapter 6.

7. See Table 2.1 for definitions of true private sector.

8. Assuming state-owned agriculture accounts for one percentage point of the total agricultural GDP.

9. It is done by taking one percentage point of state-owned share from agriculture sector.

10. The People's Daily, Overseas Edition, 7 October 1999:2.

11. In 1994, as the ministry in charge of the government's economic affairs, the SETC sent a report Suggestions on Revitalizing Small State-owned Enterprises to Vice Premier Wu Bangguo who was in charge of enterprise reforms. In September 1995 the policy was formally announced by the central committee of the CCP in one of its plenary sessions and was put into the suggestions to the ninth five-year plan.

12. In the Law of Incorporation, two kinds of limited liability companies are defined. One is ordinary limited liability companies, the other is limited liability shareholding companies. The distinction is purely for registration purpose and ignored in most statistical publications. For a discussion of the registration of different types of ownership, see Chapter 10. 


\section{Government documents}

1. Directives on Several Issues of the Agricultural Production Responsibility System, the Central Committee of CCP, September 271980.

2. Directives on Issues Related to Land Used by Urban Collective and Individual Economy, Bureau of Labour, Bureau of Urban Construction, Ministry of Public Security, and Bureau of Industry and Commerce Management, May 61981

3. Directives on Issues of Material Supplies to Urban Individual Businesses, Bureau of Industry and Commerce Management, Ministry of Commerce, Ministry of Grains, National Cooperative of Supply and Sales, Bureau of Materials, and Bureau of Labour, June 221981.

4. Policies on Urban Non-agricultural Individual Business, the State Council, July 7 1981.

5. Several Directives on How to Use New Channels and New Methods to Solve Urban Employment, the Central Committee of CCP and the State Council, October 17 1981. 


\section{Descriptions of the sample enterprises}

This chapter provides summary statistics of the sample enterprises. It discusses briefly the profiles of the four surveyed cities based mainly on aggregate statistics and then Survey information on the size of enterprises and industry distribution, and recent development and performance of these enterprises. Data are arranged to allow comparisons of private enterprises between cities and industries. The results provide important background information for the subsequent chapters discussing various issues facing private enterprises.

\section{Profiles of the four surveyed cities}

Beijing's population is 12.4 million including both urban districts and suburban counties. Shunde is a county-level city with a population of 1.4 million. Chengdu is the provincial capital of Sichuan and has a population of 9.9 million. Wenzhou is a prefecture-level city governing several counties and county-level cities, and has a population of around 7.2 million. ${ }^{1}$

In 1998, the GDP of Beijing, Shunde, Chengdu and Wenzhou was, respectively, 201 billion yuan, 26 billion yuan, 110 billion yuan, and 72 billion yuan. Per capita GDP of the four cities was, respectively, 18,400, 24,800, 11,100, and 10,000 yuan. In terms of industrial output, Beijing had 172 billion yuan, Shunde 60 billion yuan and Chengdu 122 billion yuan in 1998.

Beijing, as the national capital, is particularly sensitive to the political climate. Until recently, the Beijing government had not put forward any concrete plan to help the development of its private sector. Partly as a result, the private sector in Beijing is still in its infancy. Table 3.1 shows that although Beijing had more firms than other cities for which there were data (mainly because of its size), it had the smallest output and sales volume, indicating that its firms were relatively small.

However, the development of the private sector in Beijing has been rapid. In 1992, there were only 1,428 registered private firms, and each firm on average had registered capital of 228 thousand yuan. ${ }^{2}$ By 1998 , there were 61,113 private 


\section{Table 3.1 Basic information of the four cities' private sector in 1998}

\begin{tabular}{|c|c|c|c|c|c|c|c|}
\hline & $\begin{array}{l}\text { Number } \\
\text { (Billion } \\
\text { yuan) }\end{array}$ & $\begin{array}{l}\text { Output } \\
\text { (Billion } \\
\text { yuan) }\end{array}$ & Sales & Employment & $\begin{array}{l}\text { Corpor- } \\
\text { ation }\end{array}$ & $\begin{array}{c}\text { Types of firm } \\
\text { Sole } \\
\text { ownership }\end{array}$ & $\begin{array}{l}\text { Partner- } \\
\text { ship }\end{array}$ \\
\hline Beijing & 61,113 & 2.4 & 26.7 & - & 53,511 & 6,888 & 714 \\
\hline Shunde ${ }^{1}$ & 4,550 & 35.5 & 24.1 & 222,539 & 23 & 3,815 & 712 \\
\hline Chengdu? & 11,300 & 14.1 & 13.0 & 110,000 & 7,800 & - & - \\
\hline Wenzhou ${ }^{3}$ & 107,410 & 29.7 & 27.5 & - & - & - & - \\
\hline
\end{tabular}

Notes: ${ }^{1}$ Sales figure is for firms with more than 5 million yuan in sales; ${ }^{2}$ Output and sales figures for the first half of $1999 ;{ }^{3}$ Output and sales volume are for firms with more than 5 million yuan in sales.

Source: Data provided by local BICAMs and the statistical yearbooks of the four cities. Gregory et al., 2000, IFC Report, Figure 1.5, p.3.

firms with average registered capital of 621 thousand yuan. Among them, 87.6 per cent were limited liability companies, 1.2 per cent partnership firms, and the remaining 11.2 per cent sole ownership firms. In 1998, the municipal government issued a document calling for speeding up the development of the private sector, and the enacting of concrete policies is underway.

In terms of industrial distribution, private firms in Beijing are overwhelmingly concentrated in the tertiary sector. The number of firms in this sector was 4.4 times the number in the secondary sector.

Wenzhou has a long history of private sector development. It has almost no public firms. The size of its private sector is the largest among the four cities in terms of the number of firms and sales volume (Table 3.1). Its industries have formed several nationally renowned geographical clusters, such as electronic parts in Hongqiao, low voltage electrical products in Liushi, and buttons in Qiaotou. In addition, the garment industry is a strong pillar of the local economy.

A major problem associated with private enterprise development in Wenzhou is high land prices. One mu (one fifteenth of a hectare) of land usually costs 150 to 200 thousand yuan, depending on the location of the land. In the extreme case, the price can reach more than 300 thousand yuan per mu. To a large extent, the high price of land is caused by Wenzhou's poor land endowment (each person in Wenzhou has less than one mu of arable land) and fast industrial development. However, the high fees collected by the government may also have influenced land costs. It was estimated by the research team that the total effect of several government fees represented one third to one fourth of the capital value of the land. This suggests that not all of the incidence of fees was on land rent, and therefore that the fees increased land costs. In response to high land prices, firms have begun to move out of Wenzhou. 
Shunde's private sector began to take shape largely as a result of its privatisation program from 1992. Currently, there are almost no purely stateowned firms in Shunde. The size of its private sector is the second among the four cities in terms of sales (Table 3.1). Before privatisation, Shunde was renowned for its township and village enterprises (TVEs). Its leading industries were small home appliances such as electric fans, rice cookers, and water heaters.

After the early stage of development, large firms emerged. Currently, there are 72 firms each with an annual sales volume of more than 100 million yuan. In particular, it has become the nation's largest industrial base for home electronics, producing every kind of home electronic product except television sets. Several nationally renowned firms have emerged. They are Kelong (a major national refrigerator producer), MD (the world's largest electric fan producer and a major national producer of air conditioners), Grand (the nation's largest microwave producer), and Wanbao (the nation's largest kitchen steriliser producer). Together with Zhongshan, Nanhai, and Dongguan, Shunde is regarded as one of the four small tigers in Guangdong Province.

The private sector in Chengdu has become a significant contributor to the city's economy. In the first half of 1998 , its industrial output was 14.1 billion, accounting for 30.8 per cent of the city's total. Its GDP was 10.7 billion, accounting for 22.3 per cent of the city's total. In the period January to November 1998, the private sector contributed 607 million yuan of tax, accounting for 10.3 per cent of the city's total. In some counties, the private sector dominates the local economy. For example, in 1998, the private sector (private firms and getibu) contributed 90 per cent of the total tax revenue in Xinjin county.

In the course of development, large private firms in Chengdu have emerged. In 1992, there was no private firm with registered capital of more than 5 million yuan. By 1998, the number climbed to 260. Among them, the Hope Group, with an annual sales volume of more than 5 billion yuan, is the largest private firm in China. Among the first 20 private firms that obtained the right of direct export, Chengdu had 5 . In addition, some large private firms began to buy large SOEs, playing an increasingly significant role in the state sector reform.

\section{Size and industrial distribution}

Table 3.2 shows the distribution of employment by firm size in 1995 and 1998 for firms in the sample who provided valid information. In preparing this table, firm size is divided into four categories: no more than 50 workers, 51-100 workers, $101-500$ workers, and more than 500 workers.

Overall, the distribution of firm size in the sample did not change significantly from 1995 to 1998 , but the data do reveal that during the past three years the number of firms employing less than 51 tended to increase 
more than medium and large firms. For example, in 1998 around 61 per cent of firms employed no more than 50 employees (including the owner) as compared with 58 per cent in 1995. It is noteworthy that around 6 per cent of the firms had more than 500 employees in 1995 and the proportion remained basically unchanged in 1998. While there was a slight increase in the number of firms with 101-500 workers, the number for firms with 51-100 fell marginally over the same period.

However, there were large regional differences in firm size. For example, while small firms with no more than 50 employees were predominant in Beijing (their proportion in total private firms increased from 77 per cent in 1995 to 81 per cent in 1998), Shunde had a relatively high percentage of large firms with over 500 employees in both 1995 and 1998. The main reason that Beijing had more small-size private firms was that the development of its private sector started later and was much slower than the other cities due to its closeness to the Central government. The reason that Shunde had more large firms was that many large private firms were transformed from county and township owned firms, the so-called township and village enterprises (TVEs) that had a relatively long history of business development and networking.

Among the four cities, Wenzhou had the highest proportion of large firms in 1998 with a rapidly increasing rate. For example, firms with over 500 workers accounted for only 6.5 per cent in 1995 , not distinguishable from cities other than Shunde. But the proportion increased to 21 per cent in 1998. This was mainly the result of extensive mergers in Wenzhou in recent years. Wenzhou is renowned for small private firms producing electronic parts and lower-priced consumer goods such as garments and related products. Conglomerations of firms specialising in similar products is common and several specialised production and distribution centres have emerged in recent years to enhance specialisation and to exploit economies of scale. For example, Hongqiao specialised in producing and distributing small electronic parts, Liushi in low voltage electric products, and Qiaotou in buttons. Local competition is fierce. Out of the competition, however, a few large firms have emerged by consolidating small firms, a practice that has been encouraged by the local governments.

The proportions of small firms with less than 51 workers in the total samples in Chengdu, Mianyang and Deyang were still relatively high especially in Chengdu, but fell quite substantially from 1995 to 1998 . Meanwhile, the proportions of medium-size firms especially with the number of workers between 101 to 500 increased rapidly particularly in Mianyang and Deyang. In Mianyang, the number of medium to large firms (between 101 to 500) increased at the highest rate of 54.2 per cent from 1995 to 1998 .

Table 3.3 shows the sample firms' average size in terms of employment at two points in time, namely 1995 and 1998 . On average, Beijing had the smallest 


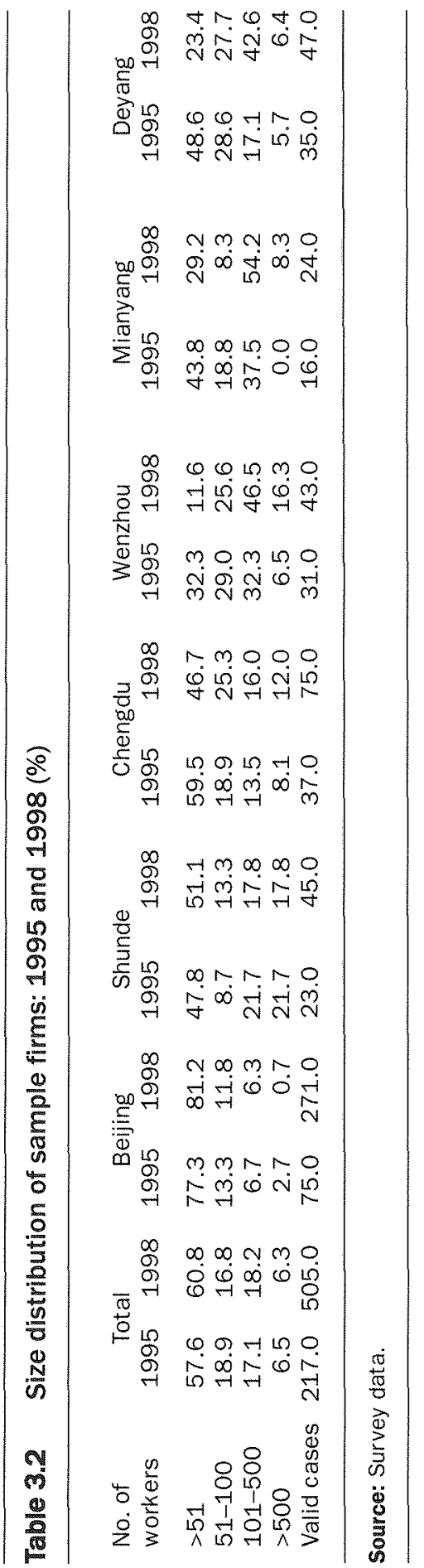


firm size in both 1995 and 1998, consistent with the late development of its private sector. Shunde had the largest firm size in 1995 and Wenzhou replaced Shunde to have the largest average firm size in 1998. While the firm's average size in Chengdu increased from 1995 to 1998, the average sizes of the private firms in Deyang and especially in Mianyang surged during the same period. For example, in 1995 the largest firm in Mianyang was 460 workers versus 800 workers in Chengdu and by 1998 the figure for Mianyang was 4,393 workers versus 3,000 workers in Chengdu.

Generally, the size distribution of the sample firms became more dispersed from 1995 to 1998 . The coefficient of variation (CV) for all the sample firms became larger and the largest firm became even larger while the smallest firm more or less kept its size during the period. While the average size of the private firms in Beijing and Shunde decreased from 1995 to 1998, it increased substantially in the other four cities. In Wenzhou and Mianyang, the average firm size increased by 1.54 and 0.89 times respectively. Again, Wenzhou's mergers in recent years could explain the increase in firm size. The decrease of the average firm sizes in Beijing and Shunde with respect to their abilities to absorb more employment could be offset by the increases in the size of the largest firms (maximum numbers) in the two cities.

Table 3.4 shows the sample firms' size in the surveyed cities by their average sales, fixed and working capital. Beijing had the smallest firm by

Table 3.3 Statistics of firm size (average employee numbers)

\begin{tabular}{lrrrr} 
& & & & \\
& & & & \\
& Employees & & Minimum & Maximum \\
Beijing & & & & \\
Shunde & 62.1 & 2.3 & 3 & 900 \\
Chengdu & 403.1 & 2.1 & 8 & 4,019 \\
Wenzhou & 114.2 & 1.6 & 4 & 800 \\
Mianyang & 152.5 & 1.4 & 13 & 1,020 \\
Deyang & 95.5 & 1.2 & 7 & 460 \\
Total & 105.8 & 1.6 & 6 & 821 \\
1998 & 129.6 & 2.6 & 3 & 4,019 \\
Beijing & & & & \\
Shunde & 47.8 & 2.3 & 2 & 1,100 \\
Chengdu & 326.8 & 2.4 & 5 & 4,438 \\
Wenzhou & 181.9 & 2.3 & 6 & 3,000 \\
Mianyang & 387.0 & 1.7 & 15 & 3,000 \\
Deyang & 317.4 & 2.8 & 10 & 4,393 \\
Total & 180.2 & 1.2 & 8 & 1,002 \\
& 146.6 & 2.9 & 2 & 4,438 \\
\hline
\end{tabular}

Source: Survey data. 
every measure and its differences with other cities were large. Shunde had the largest except for fixed capital in 1998, when Mianyang took its place with the highest average fixed capital investment. The reason that Mianyang had the largest firms in terms of fixed capital in 1998 was that it had high concentration of firms in metal and nonmetal manufacturing (see Table 3.5). Another observation from Table 3.4 is that while the average values of both sales and fixed capital for the total sample increased substantially from 1995 to 1998 , the average value of working capital actually fell (slightly) during the same period. This reduction in the value of working capital may reflect the difficulties facing private firms in financing their business activities in recent years. ${ }^{3}$

Table 3.5 shows the industrial distribution of the sample firms in 1998. Industries are grouped into eight categories based on the smaller categorisation used by the third national industrial census conducted in 1995. For all the six cities, garments and other light products were the largest industry, taking a share of 23.2 per cent of the total number of firms. Electronics and equipment were the next largest industries with a share of 16.1 per cent, and chemicals took the third position with a share of 12.7 per cent. These three industries contributed 52 per cent of the 544 firms with valid answers.

Steady and high demand for their products is common to these three industries. Garments, electronic products such as refrigerators, air conditioners and other light products enter directly into the consumer market. In addition, electronic parts, such as those produced in Wenzhou, are closely linked with consumer electronics. None of the sample firms is engaged in heavy chemicals such as oil refining, but many of them produce paints that are widely used in household renovation, a fashion which is currently spreading throughout the country. In addition, producing garments, chemicals, and electronic parts does not require much physical and human capital. The large-size home appliance companies in Shunde also started from smaller factories producing lower-priced electronic products.

Again, there were regional differences with regard to industrial distribution. For example, private firms in Beijing had a high concentration in garments and other light products, and electronics and equipment. Shunde also had, in addition to these two industries, a high concentration in chemicals. Firms in Chengdu were spread more widely across industries including food and cigarettes, garments and other light products, chemicals, machinery and electronics and apparatuses. Wenzhou had a very high concentration in machinery manufacturing and electronic products. Mianyang seemed to specialise in metal and non-metal manufacturing apart from food and cigarettes, and machinery. Last, Deyang had a high concentration in garments and chemicals as well as food and cigarettes. 


\section{Table 3.4 Sales and capital of sample firms: 1995 and 1998} (million yuan, current prices)

\begin{tabular}{lrrrrrrr}
\hline & \multicolumn{9}{c}{ Sales } & \multicolumn{2}{c}{ Fixed capital } & \multicolumn{2}{c}{ Working capital } \\
& 1995 & 1998 & 1995 & 1998 & 1995 & 1998 \\
Beijing & $5.0(62)$ & $7.0(256)$ & $8.3(32)$ & $6.5(184)$ & $0.7(23)$ & $0.6(160)$ \\
Shunde & $45.1(21)$ & $72.4(43)$ & $40.2(16)$ & $72.0(29)$ & $9.9(15)$ & $10.8(25)$ \\
Chengdu & $24.3(26)$ & $28.1(64)$ & $24.4(16)$ & $48.0(42)$ & $2.1(13)$ & $2.4(39)$ \\
Wenzhou & $13.9(34)$ & $58.4(46)$ & $16.4(24)$ & $31.7(34)$ & $1.1(20)$ & $4.1(30)$ \\
Mianyang & $10.7(17)$ & $27.9(25)$ & $19.8(11)$ & $101.4(18)$ & $0.7(11)$ & $2.4(17)$ \\
Deyang & $11.3(32)$ & $20.7(47)$ & $9.8(27)$ & $16.2(37)$ & $1.2(22)$ & $1.9(35)$ \\
Total & $15.2(192)$ & $23.0(481)$ & $17.3(126)$ & $25.6(344)$ & $2.4(104)$ & $2.2(306)$ \\
\hline
\end{tabular}

Note: The number of valid cases is listed in parentheses.

Source: Survey results.

\section{Table 3.5 Industrial distribution of sample firms, 1998 (\%)}

\begin{tabular}{lrrrrrrrr} 
Industry & All & Beijing & Shunde & Chengdu & Wenzhou & Mianyang & Deyang \\
Primary industries & 3.0 & 2.5 & 5.6 & 2.3 & - & - & 9.8 \\
$\begin{array}{l}\text { Food and cigarettes } \\
\text { Garments and other }\end{array}$ & 9.9 & 9.0 & 7.4 & 11.4 & 3.8 & 17.2 & 17.6 \\
$\begin{array}{l}\text { light products } \\
\text { Chemicals }\end{array}$ & 23.2 & 26.8 & 27.8 & 17.0 & 13.5 & 6.9 & 23.5 \\
$\begin{array}{l}\text { Metal and non-metal } \\
\text { manufacturing }\end{array}$ & 12.7 & 9.9 & 18.5 & 19.3 & 7.7 & 3.4 & 25.5 \\
$\begin{array}{l}\text { Machinery } \\
\text { Electronics and }\end{array}$ & 8.0 & 7.3 & 9.3 & 3.4 & 9.6 & 24.1 & 7.8 \\
$\begin{array}{l}\text { equipment } \\
\text { Others }\end{array}$ & 16.1 & 15.8 & 7.4 & 12.5 & 28.8 & 13.8 & 2.0 \\
Number of firms & 4.9 & 7.1 & 1.9 & 17.0 & 34.6 & 3.4 & 3.9 \\
\hline
\end{tabular}

Notes: Primary industries: coal mining, oil and natural gas, steel, metal mining, non-metal mining and timber. Food and cigarettes: food processing, food producing, beverages, and cigarettes. Garments and other light products: garments, leather, fur, timber processing, furniture, paper, printing, and sports and educational products. Chemicals: oil refining, general chemicals, medicine, chemical fibers, rubber, and plastic products. Metal and nonmetal manufacturing: non-metal products, primary steel products, primary nonferrous metal products, and metal products. Machinery: general machinery manufacturing, special machinery and equipment, and transportation equipment. Electronics and apparatuses: electronic machinery and equipment, other electronic and telecom equipment, and apparatuses and office equipment. Others: electricity and hot water supply, gas, water supply, construction, repairing, services, and agriculture.

Source: Survey results. Gregory et al., 2000, IFC Report, Table 1.1, p.4. 


\section{Evolution and performance}

Tables 3.3 and 3.4 show that the sample firms became larger from 1995 to 1998 by almost every measure. However, there were significant regional differences with regard to some indicators. For example, while employment in other cities increased, it decreased in Beijing and Shunde. In terms of sales, firms in all six cities had increases, but those in Wenzhou and Mianyang increased the fastest.

Beijing was the only city that experienced a decrease in fixed and working capital per firm. This is also shown in Table 3.6, which records the change of the total capital stock (fixed and working capital together) since the establishment of the firm. Among the 54 firms who provided the information in Beijing, 12 or 22 per cent reported a decrease in their capital. The percentage was under eight for all the other cities.

Yet, in terms of the average growth of the capital stock, Beijing did not have the lowest rate. On average, its firms were the youngest among the six cities, being in business for an average of only 3.5 years, but the average capital stock increased by 97 times. This growth rate was second only to Wenzhou, which had the longest business histories- 8.2 years on average - and the highest growth rate of capital stock, 255 times per year. This shows that the growth of firms in Beijing has been polarised: quite a few firms have shrunk, and some firms have experienced extraordinary growth rates in recent years. The high growth rate in Wenzhou may be explained both by its longer history of private sector development and by mergers in recent years. Other cities' growth rates were more moderate, but still remarkable by conventional standards.

On average, the 230 firms that provided information have survived in the market for 5.7 years and experienced a growth rate of capital of 51 times per year.

\section{Table 3.6 Growth of capital stock since the founding of the firm}

\begin{tabular}{|c|c|c|c|c|c|c|c|c|}
\hline & Decreased & \multicolumn{2}{|c|}{ No change } & \multicolumn{2}{|c|}{ Increased } & \multicolumn{3}{|c|}{ All firms } \\
\hline & Firms \% & Firms & $\%$ & Firms & $\%$ & Firms & $\begin{array}{l}\text { Years in } \\
\text { operation }\end{array}$ & $\begin{array}{l}\text { Growth } \\
\text { (times) }\end{array}$ \\
\hline Beijing & 1222.2 & 2 & 3.7 & 40 & 74.1 & 54 & 3.5 & 97 \\
\hline Shunde & 14.8 & 2 & 9.5 & 18 & 85.7 & 21 & 6.3 & 12 \\
\hline Chengdu & 7.7 & 1 & 1.5 & 59 & 90.8 & 65 & 5.0 & 9 \\
\hline Wenzhou & - & - & - & 291 & 100.0 & 29 & 8.2 & 2088 \\
\hline Mianyang & 5.0 & - & - & 19 & 95.0 & 20 & 5.4 & 29 \\
\hline Deyang & 2.4 & - & - & 40 & 97.6 & 41 & 7.1 & 30 \\
\hline All & 8.7 & 5 & 2.2 & 205 & 89.1 & 230 & 5.7 & 292 \\
\hline
\end{tabular}

Source: CEO survey. 
Table 3.7 Pre-tax profitability of sample firms by city: 1995 and 1998 (1,000 yuan in current price)

\begin{tabular}{lrrrrrr}
\hline & $\begin{array}{c}\text { \% of profitable } \\
\text { (1,000 yuan) }\end{array}$ & \multicolumn{2}{c}{$\begin{array}{c}\text { Profit per worker } \\
\text { (yuan/yuan) }\end{array}$} & Return to capital \\
City & 1995 & 1998 & 1995 & 1998 & 1995 & 1998 \\
Beijing & 70.0 & 67.2 & 9.9 & 9.0 & 0.54 & 0.49 \\
Shunde & 91.7 & 87.5 & 43.4 & 31.6 & 0.40 & 0.23 \\
Chengdu & 81.8 & 88.6 & 37.7 & 55.0 & 0.42 & 0.13 \\
Wenzhou & 75.0 & 87.1 & 28.3 & 31.2 & 0.71 & 0.53 \\
Mianyang & 87.5 & 90.0 & 30.1 & 29.0 & 0.49 & 0.30 \\
Deyang & 95.0 & 96.4 & 24.7 & 21.8 & 0.40 & 0.37 \\
Total & 81.0 & 78.5 & 25.2 & 9.6 & 0.50 & 0.40 \\
\hline
\end{tabular}

Note: Return to capital is defined as a ratio of profit to firms' total capital. Source: Firm survey.

Of the firms, 8.7 per cent of them (20 firms) experienced a fall in their capital stock, 89.1 per cent (205 firms) experienced an increase, and the rest, about 2.2 per cent ( 5 firms), remained unchanged. Viewed from this perspective, it can be seen that there has been progress in developing and expanding private firms in these cities. But we need to look at other indicators, especially the profitability of the sample firms, to judge the overall performance of the private firms.

Table 3.7 shows that, generally, the profitability of the surveyed firms was lower in 1998 than in 1995. The percentage of profitable firms declined from 81 per cent in 1995 to 78 per cent in 1998. During the same period, annual profit per worker declined from 25,200 yuan to 9,600 yuan, and return to capital declined from 50 per cent to 40 per cent. It is noteworthy that the calculation in the table does not take into account the effect of inflation, thus exaggerating return on capital when prices are rising, as they were in the mid 1990s.

The contrast between increased sales and capital stock, and reduced profitability among the sample firms is interesting. The growth of sales and capital stock might be the consequence of an enlarged market size and the decline of profitability, but on the other hand, it might be the result of increased competition. The economic slowdown since 1997 may have played a role in increasing price competition, but it is interesting to find that the increased competition did not take a toll on firms' sales.

Profitability of private firms was not distributed evenly across regions. For example, Beijing had the lowest percentage of firms in the black and the lowest profit per worker in both 1995 and 1998. In particular, its profit per worker was only about 40 per cent of the lowest of the five other cities. However, its return 


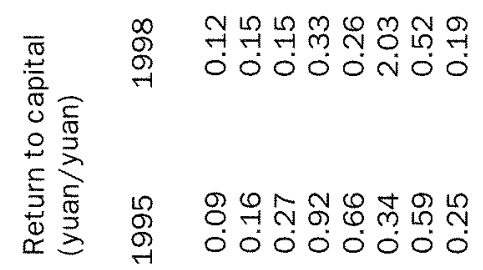

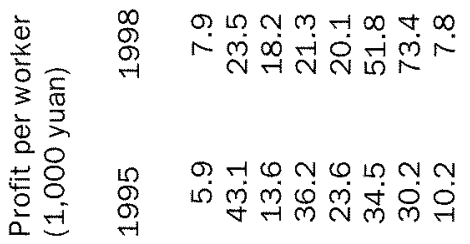

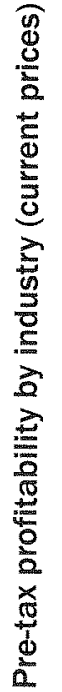

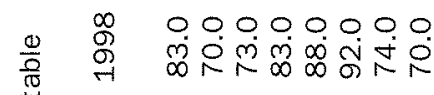

는

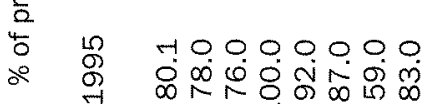

$\frac{\frac{10}{50}}{\frac{10}{0}}$

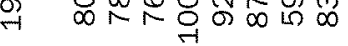

o 00000000

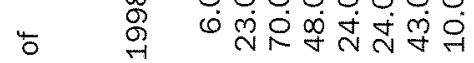

$\sum_{\sum}^{\frac{1}{2}} \sum_{E}^{n}$

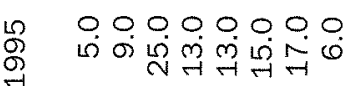

$\frac{0}{0}$
$\frac{0}{2}$
0
$\frac{0}{0}$
$\frac{5}{5}$
$\frac{20}{=}$
$\frac{1}{0}$

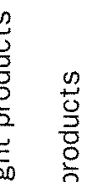
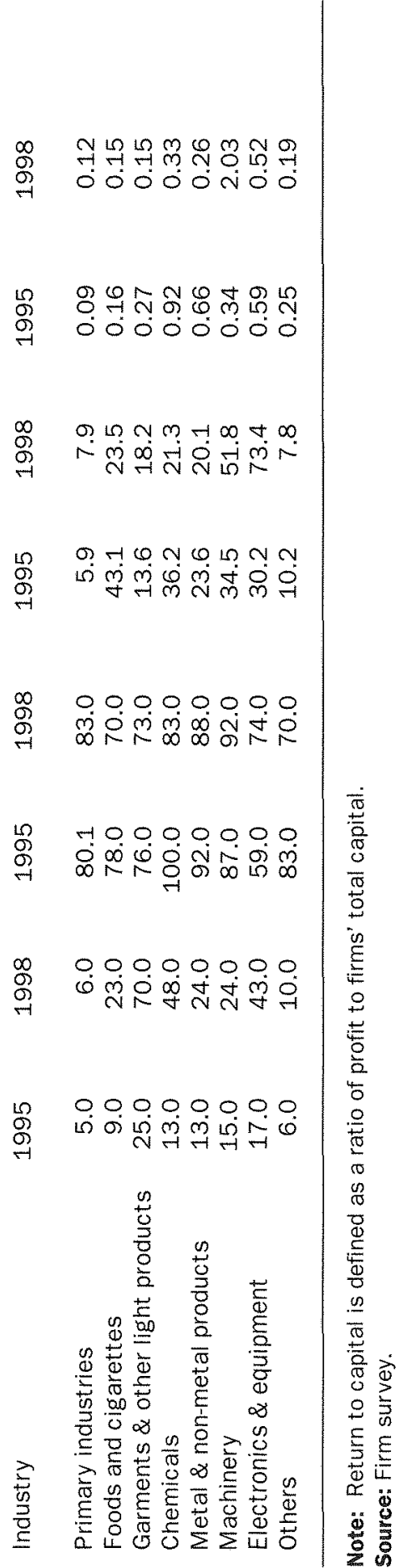
to capital was the highest in 1995 and second in 1998. This contrast shows that Beijing's firms tended to be more labour-intensive than those in the other cities. While the return to capital declined in all the six cities, decline in the number of profitable firms and profit per worker was concentrated mainly in Beijing and Shunde. Chengdu and Wenzhou experienced increases in both indicators, and Mianyang and Deyang had an increase in the number of profitable firms but experienced decreases in profit per worker.

Different performances were also observed across industries and firm size. Table 3.8 shows that firms in machinery and electronics and equipment performed the best on all three indicators, namely the percentage of firms in the 'black', profit per worker, and return to capital, increased significantly in 1998 over 1995. Firms in primary industries followed. Firms in all the other industries experienced decreases in all three indicators. Firms producing products experiencing high demand growth, i.e., electronics and related products, performed better than firms in other sectors.

In terms of firm size, the three indicators improved for the largest firms in 1998 , but all worsened for the smallest firms. The results for the two mediumsize categories were mixed (Table 3.9). In 1998, larger firms performed better than smaller firms in terms of the percentage of profitable firms and profit per worker. The results for return to capital were mixed: firms of 101 to 500 employees had the highest rate of return, and firms of 51 to 100 employees had the lowest. Large firms have fewer competitors in the market, and tend to adopt laboursaving and capital-intensive technologies. In addition, large firms usually acquire a unique technological or product advantage either in the end-product market or in the market for intermediate goods. There is also a tendency for the large firms to include those which have been commercially successful in recent years. These factors largely explain the differences in profitability of the sample firms.

\section{Table 3.9 Pre-tax profitability by firm size (current prices)}

\begin{tabular}{|c|c|c|c|c|c|c|c|c|}
\hline \multirow[b]{2}{*}{ Size } & \multicolumn{2}{|c|}{$\begin{array}{l}\text { Number of } \\
\text { firms }\end{array}$} & \multicolumn{2}{|c|}{$\%$ of profitable } & \multicolumn{2}{|c|}{$\begin{array}{l}\text { Profit per worker } \\
(1,000 \text { yuan) }\end{array}$} & \multicolumn{2}{|c|}{$\begin{array}{l}\text { Return to } \\
\text { capital } \\
\text { (yuan/yuan) }\end{array}$} \\
\hline & 1995 & 1998 & 1995 & 1998 & 1995 & 1998 & 1995 & 1998 \\
\hline$<51$ employees & 50 & 128 & 78.0 & 74.2 & 20.0 & 5.9 & 0.51 & 0.15 \\
\hline 51-100 employees & 20 & 51 & 70.0 & 76.5 & 18.3 & 24.0 & 0.34 & 0.08 \\
\hline 101-500 employees & 23 & 50 & 100.0 & 88.0 & 35.2 & 44.0 & 0.65 & 1.17 \\
\hline$>500$ employees & 6 & 15 & 83.3 & 93.3 & 57.7 & 56.8 & 0.30 & 0.35 \\
\hline
\end{tabular}

Source: Firm survey. 
In summary, by all measures, Beijing's private firms were on average the smallest in size amongst the six cities. Shunde had the largest firm size on average, but it has also experienced a considerable decline in employment and profitability in recent years. In contrast, the other four cities, especially Chengdu and Wenzhou, made significant progress in terms of employment, sales, capital accumulation, and profitability. Generally, larger firms fared better than smaller firms did in the same period.

As a result of government policy of 'letting go the small ones', a lot of small size SOEs have been privatised in various forms (sold, leased and taken over by private firms) in recent years. How are these privatised firms performing in comparison with ordinary private firms? A finding from such comparison would be interesting in that implications for constraints on the performance of privatised firms could be drawn.

There are 24 privatised firms altogether in the sample. Among them, only eight firms provided valid data to be used for calculating profitability. A simple comparison between these eight firms with 49 other firms with valid data in terms of their respective profitability (mean value) shows that the average pretax return on capital as defined in Table 3.7 for these two types of firms are 0.8 per cent and 15.5 per cent, respectively. That is, privatised firms on average have a much lower profitability than other private firms. The poor performance of these privatised firms in comparison with other private firms may indicate that there are some constraints on the operation of privatised firms possibly associated with the transitional period. However, due to the limited sample size as well as the poor statistical results, ${ }^{4}$ caution needs to be taken in interpreting these results.

\section{Notes}

1. The data are from various provincial and metropolitan statistics.

2. Registered capital is amount of capital a firm reports to BICM when it gets formally registered. It provides a kind of base line for BICM to monitor firms' performance and adjust their business status accordingly. For example, Article 13 in Chapter 3 of the Procedure for Registration for Private Enterprises issued by State BICM on 20 July 1991 requires that private enterprises whose real capital increases (or decreases) by 20 per cent of their registered capital come back to BICM applying for registration for change. For those whose registered capital fall by more than 20 per cent, BICM will re-evaluate their scope and way of business operation. According to the same article, limited liabilities firms cannot reduce the amount of their registered capital.

3. However, data in Table 3.4 indicate that the average value of working capital for each city show a trend of increasing except Beijing which marked a fall from 0.74 in 1985 to 0.57 million yuan in 1998 .

4. The $t$-statistic for the two means is 1.47 , showing that they are not statistically different. This may be due to the fact that the standard deviation of privatised firms (13.7 per cent) is much larger than that of the other firms (3.9 per cent). 


\section{4}

\section{Market competition}

This chapter analyses market competition faced by the sample firms with special emphases on the barriers to market entry, business competitors and partners, the role of networks, and reactions to market irregularities. Before discussing these issues, a brief description of China's general macroeconomic conditions in recent years is provided.

\section{Macroeconomic conditions}

The year 1992 marked the beginning of a new round of exceptional expansion of the Chinese economy. As inflationary pressure gradually built up in the economy, the government began in late 1993 to implement deflationary measures. These measures were effective. In 1994 the inflation rate was 21.7 per cent, ${ }^{1}$ by 1996 , it had been lowered to 6.1 per cent. By July 1997 when the East Asian financial crisis broke, China had already begun its deflationary path.

In the meantime, the economy kept growing, albeit at a slower rate (GDP grew by 13.5 per cent in 1993 and 8.8 per cent in 1997). Consequently, China's deflationary measures were hailed as an economic soft landing. However, these measures, together with the Asian financial crisis, began to take a toll on the economy in 1998-99. The growth of aggregate demand had been lowered considerably.

China was not directly hit by the East Asian financial crisis largely because of its strong macroeconomic conditions after onset of crisis and the restrictions on the free convertibility of its currency and the insulation of its financial sector from the outside world (Song 1998). In the wave of currency depreciation that spread in East Asia, China stood the test and has won the applause of the international community by not devaluing its currency. However, China was affected by the crisis as its exports began to decrease in late 1998, mainly as a result of appreciation of the effective exchange rate, and because the purchasing power of the Southeast Asian countries decreased as a result of the crisis. As these countries began to recover, China's export growth also increased. China's export growth accelerated from late 1999. 
However, problems of structural imbalances in the Chinese economy characterised by over-capacity and over-supply in manufactured goods (both producer and consumer goods) markets, were persistent and became one of the fundamental causes for ongoing deflation. ${ }^{2}$ Such imbalances and the resulting price deflation are putting severe pressure on both state-owned and non state-owned including private firms.

At the macroeconomic level, one contractionary effect of deflation is to raise real interest rates for any given nominal rate, thereby reducing investment and other interest-sensitive expenditures. ${ }^{3}$ Reduced investment implies slow growth. This is devastating since China's economy needs to grow at a high speed to create jobs for workers laid off from the restructuring of state-owned enterprises.

Deflation also has the negative effect of delaying consumption. Many Chinese people expect lower prices in goods and services and therefore wait to make a purchase. This can create a dangerous deflationary spiral: weak demand may lead to more downward pressure on average prices, resulting in further spending delays (Schlevogt 1999).

At the micro level, firms have long begun to feel the effects of the deflationary measures. Liquidity began to be a problem for many firms as soon as these measures were put into effect in the mid 1990s. Private firms were hit hardest because they are in a disadvantageous position in terms of getting loans. Some firms in the coastal areas turned to foreign loans through their subsidiaries in Hong Kong. As Chapter 3 showed with data from the sample firms, firm profitability and employment in some cities were lowered considerably in the period of contraction.

A fundamental cause for the steady decline in growth rate and persistent deflation from mid 1997 to mid 1999 was that growth has been driven mainly by large-scale government investment (fiscal expansion), which was not matched by the increases in domestic non-state investment including private investment. Faced with satiated product markets due to over-supply, and low profit margins due to increasing competition and in reaction to weak market demand, investments from the non-state sector slowed down considerably.

A practical way of reviving non-state investment in the circumstances of deflation was to open more sectors for investments from the non-state sector, by relaxing market entry barriers which had limited participation in certain sectors by non-state including private firms. In so doing, the economy as a whole benefitted, since the non-state sector in general performs more efficiently than the state sector. The further relaxation of market entry barriers to the non-state sector also increased pressure for faster reform in SOEs, banking and financial areas.

\section{Market entry: openness and requirements}

Although private firms have been officially allowed to exist for more than 10 years, there are still various government restrictions on market entry by private firms. 
The central government stipulates that fifteen types of businesses should exclude the entry of private firms. ${ }^{4}$ Furthermore, localities have the discretion to impose only part of the restrictions under a general guideline which rules that private firms' entry to the following industries should be restricted. They are (1) industries using very scarce resources; (2) industries that are vital to the national economy; and (3) industries whose products have certain public hazards. Since there are not precise criteria, there is room for officials' personal judgments.

Various forms of market barriers such as industrial monopoly structures and market size were regarded by some of the sample firms as adverse influences on their business operations. For example, the survey results indicate that entry barriers to major products are encountered by between 26-28 per cent of firms. The survey results also indicated the presence of small regional differences in entry barriers for private firms. For example, for the first major product, the highest percentage was in Wenzhou, 33 per cent, and lowest was in Deyang, 22 per cent.

Table 4.1 shows the distribution of the types of entry barriers. Five entry barriers, namely licenses, general policy restrictions, local protection, industrial monopoly, and market size, were mentioned by the firms. The first three are related to central and regional government regulations and policies, whilst the last two are related to market structure. It is noteworthy, though, that the last two might be based on firms' perception of the market rather than objective realities. Among the 69 answers, 75 per cent were directed to the first three kinds of barriers. Beijing had the highest number of answers (35 firms) with business licenses ranked the highest ( 31.4 per cent), followed by policy restriction, industry monopoly and local protection.

In the course of the study, the research team learned that there were several kinds of licenses that prohibited private firms entering into certain industries. For example, private firms could not engage in recycling, the taxi business, and the production of products considered a public hazard. Box 4.1 provides an example of how a taxi business in Beijing worked around government restrictions by establishing a guakao unit for itself. In Shunde, the local BICM provided an example of the effects of government licensing for high-pressure containers. A collective firm produced such containers before it was privatised. However, after it was privatised, it could no longer continue its production, because the government does not issue licenses to private firms to produce this kind of product.

Private firms were restricted in establishing medicine distribution or direct export businesses. The restricted entry to medicine distribution has done damage to the economy. One consequence of this restriction is the existence of regional monopolies. Licensing restrictive and the medicine market is divided into small fragmented pieces based on administrative jurisdiction. For example, 
Table 4.1 Types of entry barriers (\% of firms with 'yes' answer)

\begin{tabular}{lcccccr}
\hline City & Licenses & $\begin{array}{c}\text { Policy } \\
\text { restriction }\end{array}$ & $\begin{array}{c}\text { Local } \\
\text { protection }\end{array}$ & $\begin{array}{c}\text { Industry } \\
\text { monopoly }\end{array}$ & $\begin{array}{c}\text { Market } \\
\text { size }\end{array}$ & $\begin{array}{c}\text { No. of } \\
\text { firms }\end{array}$ \\
Beijing & 31.4 & 25.7 & 11.4 & 25.7 & 5.7 & 35 \\
Shunde & 33.3 & 55.6 & 11.1 & - & - & 9 \\
Chengdu & 50.0 & - & 33.3 & 16.7 & - & 6 \\
Wenzhou & 50.0 & 33.3 & - & - & 16.7 & 12 \\
Mianyang & 50.0 & 50.0 & - & - & - & 2 \\
Deyang & - & 20.0 & 20.0 & 40.0 & 20.0 & 5 \\
Total & 34.8 & 29.0 & 11.6 & 17.4 & 7.2 & 69 \\
\hline
\end{tabular}

Source: CEO survey.

a medicine distributing company in Shunde cannot undertake business in Guangzhou, a place with a much higher demand.

A direct consequence of such restrictions is that consumers have to pay higher prices for medicines. In an interview with a manager of a medicine distributing company in Shunde, it was interesting to find that the manager said he welcomed competition. His company enjoyed a high profit but he was quite conscious of the social cost of the license restriction and regional monopoly, and fully prepared for more competition. He was confident that his company would win a share of large cities' medicine markets.

In the case of direct access to export, private firms have been in a disadvantageous position. Before 1998, private firms were not allowed to export directly although this right had been granted to select state firms for several years. Starting in 1998, the government began to grant direct export licenses to selected private firms. Currently, about 150 private firms have the licenses. Besides the advantages associated with the direct business link with foreign companies, having license also enables a firm to hold foreign currencies and by-pass trading companies. This gives them access to value-added from exporting, as well as to the tax rebates associated with exports.

The effects of entry barriers may differ across firms of different sizes (see Table 4.2). It is clear that firms of all sizes had complaints about government licensing and restrictions. Larger firms were more concerned than others with local protection. This might be because larger firms sold their products outside their own provinces while smaller firms tended to sell locally. In addition, larger firms enjoyed larger markets and had larger shares in these markets. This was why larger firms with more than 100 people were less concerned with industrial monopoly and market size than smaller firms. 


\section{Box 4.1 W Arts Co. Limited}

W Arts Co. Limited, located in Beijing, was established to avoid government restrictions on private taxi companies. Before the company was established, the manager ran a taxi company that was registered as a subsidiary of a collective firm. This arrangement is known as guakao, literally meaning 'get backed', the private firm is called a guakao firm, or a 'red hat' firm, and the unit, a state firm, collective firm, or a government agency, providing the backup is called a guakao unit. In 1996, the manager's guakao unit, i.e., the collective firm, was transformed into a shareholding company, but the taxi business was excluded from this arrangement. As a result, the company became a private company and lost the privilege of continuing the taxi business because the government policy states that only companies owned by a bureau level unit can operate in the taxi business. To meet this requirement, the manager approached the district government for assistance. Since the taxi business provides considerable local tax revenues, the district government decided to set up a new company called W Arts Co. Limited, a trade company specialising in jewellery and arts articles. This new company was partly owned by the district government and qualified as a collective firm, or guakao unit, for the taxi business.

The manager also owned another trading firm with a state firm as its guakao unit. Now, she could operate on three fronts: a taxi business, a collective firm, and a state firm. This arrangement was made to avoid political risks and to get around government restrictions. Although the Fifteenth Congress of CCP gave the private sector the same status as the state sector, the manager did not change this arrangement immediately, preferring to wait for restrictions on private firms to be lifted.

\section{Competitors, partners, and the role of network}

Amid the slowing of the economy and shift from a seller's market to a buyer's market due to over-supply of many manufactured products in the late 1990s, market competition has been fierce. This is shown by the answers provided by the sample firms to the question of the competitiveness of the market of their major product. Among the 501 firms providing an answer, 56 per cent said the market competition was very intense, 41 per cent saidt it was intense, and only 3 per cent said that their major products did not have competition.

It is interesting to find that the competitors of the sample firms were overwhelmingly private firms. In the answer to the question: 'who were your competitors?' some 46 per cent of the $338 \mathrm{CEO}$ s interviewed said they were small domestic private firms, and 35 per cent said they were large domestic private firms. In contrast, only 12 per cent thought state firms were their competitors. The per centages for illegal imports and smuggled goods as competitors were 9 per cent and 13 per cent, respectively (the percentages may not add to 100 per cent because the question allowed for multiple answers).

The high degree of competition among private firms themselves can be a result of the increasing number of private firms in the economy, which include 
Table 4.2 Types of entry barriers by firm size (\% of firms with 'yes' answer)

\begin{tabular}{lcccccrrr}
$\begin{array}{l}\text { Size of } \\
\text { employment }\end{array}$ & Licenses & $\begin{array}{c}\text { Policy } \\
\text { restriction }\end{array}$ & $\begin{array}{c}\text { Local } \\
\text { protection }\end{array}$ & $\begin{array}{c}\text { Industry } \\
\text { monopoly }\end{array}$ & $\begin{array}{c}\text { Market } \\
\text { size }\end{array}$ & $\begin{array}{c}\text { No. of } \\
\text { answers }\end{array}$ & $\begin{array}{c}\text { \% of } \\
\text { answers* }\end{array}$ \\
$<51$ & 22.6 & 29.0 & 6.5 & 29.0 & 12.9 & 31 & 10.3 \\
$51-100$ & 50.0 & 12.5 & 12.5 & 25.0 & - & 8 & 9.6 \\
$101-500$ & 37.5 & 37.5 & 18.8 & - & 6.3 & 16 & 17.8 \\
$>500$ & 80.0 & - & 20.0 & - & - & 5 & 16.1 \\
\hline
\end{tabular}

Note: * Percentage of firms providing an answer in the total number of firms in a size category.

Source: CEO survey. Gregory et al., 2000. IFC Report, Table 4.1, p.38.

newly established, privatised SOEs, gaizhi firms and 'red hat' firms. The high degree of competition among private firms can also be a result of the concentration of private firms in several industries. This can be particularly true in rural areas where many small private firms are producing similar lowgrade products and competing with each other and with other TVEs. This second explanation is supported by the current study that found that private firms tended to form clusters in terms of both location and industry. Such clusters tend to deepen degrees of industrial specialisation, increase economies of scale, enhance efficiency and widen the scope for development of private enterprises. Local governments' policy of developing hi-tech areas such as in Beijing and Chengdu help foster the formation of industrial clusters.

The low degree of competition between private firms and SOEs may indicate that private firms are deterred from entering sectors, which have been dominated by SOEs. It can also be said that private firms may not have strong incentives to enter SOE-dominant sectors since many of these sectors have been characterised by over-capacity and low profitability, except in those areas where market potential can be realised by changing the ways of business operation, namely having private participation.

What are the forms of competition? In the CEO survey, 49 per cent of the CEOs believed that the major form of competition that their competitors used was price cuts. This high percentage is contrasted with the proportion of 23 per cent of CEOs who regarded technology as their competitors' main means of competition. It is also noteworthy that 21 per cent of the CEOs thought that government support played a role in helping their competitors.

The economic slowdown and over-supply of products have intensified price competition among firms. Many small firms cannot survive squeezed profit margins and go bankrupt. Low price levels also put heavy pressure on larger firms. Few 
firms can stand the pressure. Led by consumer electronics and motor industries, the economy has experienced several rounds of price cuts. ${ }^{5}$ Government's call for self-enforced higher prices has never been respected for long.

To accommodate the price cut, many firms, especially smaller firms, have lowered the quality of their products. This trend is reinforced by the existence of numerous unregistered small firms. These firms neither pay taxes nor care about long-term reputations. As a result, they have more room and more incentives to cut their prices. Many CEOs expressed their dissatisfaction with the government's inability to close unregistered firms. Smaller firms felt more of the damage because they had smaller markets that also had lower entry barriers in terms of both capital and technology.

Another acute problem is the piracy of new technologies. Box 4.2 shows the torment of a technological leader of the paint industry in dealing with piracy. The research team found in the interviews with CEOs that large firms feared smaller firms' piracy, and smaller firms feared unregistered firms' piracy. Competition increases the efficiency of the economy, but only when effective legal and administrative systems provide firms with an equal starting basis and necessary protection. In a business environment that lacks such effective legal and administrative infrastructure, excessive competition only leads to inefficiency and market disorder.

Turning to business partners, we begin by looking at the types of partners the sample firms had. In this regard, the CEO survey provides useful information. From the supply side, 29 per cent of the 338 firms had the state sector as at least suppliers, 41 per cent had the domestic non-state sector, and 9 per cent had foreign firms. From the demand side, 42 per cent, 44 per cent and 10 per cent had the state sector, domestic non-state sector and foreign firms as at least customers, respectively.

Specifically, the average percentage of sales to the state sector of all the firms was 46. These figures show that the non-state sector was slightly more

\section{Box 4.2 Firm J's conquest of the market}

Firm $J$ is a private firm in Shunde and a large paint company. It has been the market leader because of constant technological innovations. Because of this, it has also been the target of piracy from some of the 100 smaller paint firms in Shunde. Small firms can get a new formula either by luring workers in Firm $J$ to work for them or simply by paying Firm J's current employees for information. Firm $J$ attempted to drive the imitators out of the market by lowering prices. The owner was confident that the company's large profit margin would allow it the flexibility to cut prices and drive out smaller imitators. However, as soon Firm J lowered its prices, smaller firms set their prices even lower, simultaneously lowering their quality. Firm J's concern for its reputation prevented it from lowering its quality. In the end, the owner had to abort his move to conquer the market. 
important than the state sector as a market. Nevertheless, the state sector still played a major role. Compared with finding that the sample firms competed overwhelmingly with private firms, this finding is especially interesting. The contrast seems to suggest that the state sector and the nonstate sector constitute two different markets between which competition is low, but the demand and supply linkages are strong.

However, there are also remarkable regional diversities. For example, on average, firms in Beijing sold 59 per cent of their output to SOEs, but firms in Shunde only 25 per cent. The percentages of the other four cities spread between 38 and 50. Most of the private firms selling to SOEs produce parts for large firms that dominate the end product market. Shunde was unique in that it had large private firms producing end products.

The CEO survey also provides information on a firm's stable customers and suppliers. Specifically, 85 and 84 per cent of the CEOs said they had stable customers and stable suppliers, respectively. As for types of stable buyers, 26 per cent of the CEOs indicated they were government agencies, 46 per cent state-owned firms, 50 per cent non-state firms, and 42 per cent foreign companies. For stable suppliers, the corresponding percentages are 0 per cent, 45 per cent, 58 per cent, and 39 per cent. These figures show that the sample firms' business partners covered a wide range.

How did they establish their business ties with their partners? Among the 338 interviewed CEOs, 64 per cent said they established the ties with their customers gradually through their own marketing efforts; 21 per cent said that their partners were introduced by friends or family members; 19 per cent said their partners were friends, and 3 per cent family members. As for stable suppliers, 48 per cent of the firms found them by their own efforts; 37 per cent found them by the latter's marketing efforts; 24 per cent said the partners were introduced by friends and family members; 10 per cent said the partners were their friends, and none said that the partners were family members.

These figures provide interesting insights into the role of networks in a private firm's market operations. Family members are seldom business partners of a private entrepreneur, but quite a few of them do business with friends, and a lot of them do business with people introduced by friends or family members. Therefore, networks play a significant role in a private firm's market operations. When asked about the role of family and friends in material supply and product sales, the percentage of CEOs who said the role was important was 30 per cent and 46 per cent, respectively. However, private firms also rely heavily on the 'faceless' market to find customers and suppliers. Private firms like to have the combination of the intimacy of a network and the opportunities of the market. 


\section{Firms' reaction to the market conditions}

Facing the economic slowdown and wide spread enterprise arrears in the late 1990s, firms were becoming more cautious in selecting their customers. ${ }^{6}$ Because firms were operating under a tight liquidity constraint, losing one payment may have meant bankruptcy to them. Many of the sample firms reduced their business volumes in order to avoid deferred or dead payments. 'If you do not have a deal, you are not going to die immediately; but if you have done a deal without payment, you are going to die quickly.' The research team heard this saying quite often in the Survey. To get the information on the payment ability of a customer, a private firm relies on contacts with firms that have done businesses with that customer. Only if the customer has a good record of payment will the firm lock in a deal with it.

Another way of avoiding deferred or dead payment is to reduce business in other provinces. Due to local protectionism, it is difficult to win a lawsuit in another province. People are more likely to get a fair verdict and better enforcement in their own province. Smaller firms prefer to do business with larger firms as debts are not as likely to be deferred.

In addition to becoming cautious in choosing customers, firms also become conservative in choosing the methods of payment. Many sample firms asked for a deposit from their customers when products were sent out; others asked for cash payment. Those two measures definitely reduced their sales volumes, but reduced the risk of running at a loss.

Facing intense competition, small firms without a technological edge feel helpless. The only way for them to survive is to cut their prices as well as the quality of their products. However, there are also firms that maintain quality and do not join the wave of price cuts. For example, a small firm in Shunde specialising in high quality faucets never lowered its prices. In Beijing, a large garment company lowered its total output and concentrated on its higher-end products in order to sustain its profit. It was found in the survey that two types of firms fared the best in the market. One engaged in active technological innovations and possesed unique technical advantages. The other had unique market or supply channels. For example, a firm in Chengdu had a large share of the seafoods consumed in the star restaurants in the city. It did so by having a good supply channel from the coastal areas.

To minimise the loss created by piracy, firms sought to speed up their technological innovations. This was especially important for firms above a certain size. Such firms could not join the ranks of smaller firms and merely survive by price competition. Speeding up technological innovations helped a firm in two ways. One was for it to occupy a unique technological niche and maintain its market share. The other was to make imitation less profitable because the market demand shifted to new products. 
An alternative to technological innovations as a means of avoiding piracy was for firms to police their products themselves. The common practice was to ask salespeople to identify pirated products and report to headquarters. The headquarters then contacted the local government of the city where the pirated products were found. In coastal areas, local government usually responded and took measures to stop the production and sales of the pirated products. For example, a Beijing shirt firm found that one of its patented shirts was imitated by a Shanghai firm and sold in one of the local department stores. The firm informed the store and the store did not sell the shirt any more. In another example, a Shunde bed manufacturer found that there was a Shanghai factory using its brand. The firm informed the Shanghai government, and the latter closed the factory.

However, not all local governments were willing to close factories operating in their jurisdictions. In this circumstance, some firms resorted to illegal methods to close the pirate factories. For example, a white wine company in Shunde found that a small factory in a nearby city was using its brand when it produced white wines. It then brought a truckload of employees to destroy the factory. Realising that its production was illegal, the owner of the small factory did not report to the local government. Obviously, the action of the wine company violated the law; but with the lack of legal protection provided by the government, this kind of action was an effective substitute. However, it is dangerous if this kind of unlawful self-protection spreads because it will destroy people's confidence in the country's legal system. Ultimately, government action to enforce laws which define property rights is the only solution to the problem.

\section{Notes}

1. If not specified, figures in this subsection come from $\mathrm{Yi}$ and Zhao (1998).

2. Another key cause for deflation is weak domestic demand. A partially reformed economic system and new reform measures aimed at deepening the reform bring about uncertainties among residents. With uncertainties associated with various reform programs such as housing, pension, health and education, residents continue to increase savings at the expense of consumption. To the extent that the changes in consumption reduce demand for domestic products, domestic prices will tend to fall.

3. Fernald and Babson (1999).

4. See Appendix to this chapter.

5. Cutting prices to secure market shares is common among enterprises and retailers given the situation of over-supply of goods. A typical example is the socalled 'price war' for colour TV among the big TV producers.

6. Issues of enterprise arrears will be discussed in detail in Chapter 5 . 


\section{Appendix 4.1: Businesses with restricted entry for private firms}

In the following list of the 15 types of businesses, those with * are imposed in Beijing.

1. Production and selling of gold and silver products.

2. Taxis.*

3. Primary real estate market (in Beijing, private firms can engage in the primary real estate market by obtaining a license from the government).

4. Radio and audio products. ${ }^{*}$

5. Safety products, rubber products.

6. Pressure containers.

7. Inflammable products.*

8. Radio transmission equipment.*

9. Anaesthetic, psychiatric and radiate medicines.

10. Recycling production.

11. Air guns and hunting riffles.

12. Antiques designated by the government.

13. Important raw materials.

14. Copper, steel, iron, and platinum.

15. Polyethylene products.

Source: Information provided by Beijing BICM. IFC Report, 2000, Box 4.1, p.37. 


\section{5}

\section{Finance}

Finance is a big problem for private firms in China as is clearly revealed in responses by the sample firms. This chapter discusses the financial position of the sample firms including enterprise arrears, access to formal loans, the role of informal loans, overseas financing, access to equity financing, and possible reforms to the financial sector to accommodate private sector development.

\section{The financial position of the sample firms}

Table 5.1 reports sources of the initial capital of the survey firms based on the CEO questionnaire. The majority of the survey firms started predominantly on self-financed capital. In Beijing, Wenzhou and Chengdu more than 90 per cent of the surveyed firms relied on self-financed capital to begin their businesses, including banks and other financial or nonfinancial institutions. Other sources of financing including banks, other financial and non-financial institutions played a minor role, except that bank loans were significant in Mianyang, Deyang and Shunde.

The amount of capital financed by entrepreneurs themselves tended to be lower for firms that had been operating longer. This may reflect the situation in privatised and gaizhi firms, in which entrepreneurs generally needed to inject less initial capital into business operations. These firms tended to rely more on funding from banks and other institutions over time. This is shown in the increases in percentages of firms operating for 5-10 years, and more than ten years, that relied more on these sources of financing.

Table 5.2 reports information on business financing by years (1995 and 1998), and by cities and firm size in 1998. First, like the situation of firms' initial capital, a considerable number of private firms continued to rely mainly on self-financing and retained profits for business operations. Together these two have become dominant sources of business financing for firms in all areas except Mianyang where loans from both SOBs and credit unions played quite important roles in financing private firms.

Second, the percentage of firms relying on retained profits fell from 1995 to 1998 while the role of self-financing increased during the same period. Also, except for selling equity, which increased slightly from 1995 
Table 5.1 Sources of firms' initial capital (\% of firms with valid data)

\begin{tabular}{lcccc}
\hline & Self-financed & Bank loans & Institution & Other \\
All & 90.5 & 4.0 & 2.6 & 2.8 \\
By city & & & & \\
Beijing & 96.1 & 0.3 & 2.0 & 1.1 \\
Shunde & 87.1 & 6.5 & 6.5 & - \\
Chengdu & 91.5 & 2.8 & 2.1 & 3.6 \\
Wenzhou & 97.3 & 1.1 & 0.1 & 1.6 \\
Mianyang & 73.2 & 17.9 & - & 8.3 \\
Deyang & 82.8 & 7.1 & 5.7 & 4.6 \\
By years of operation & & & & \\
<=3 years & 92.4 & 2.7 & 2.2 & 2.7 \\
3-5 years & 92.1 & 3.5 & - & 3.8 \\
5-10 years & 89.0 & 6.3 & 1.5 & 3.0 \\
$>10$ years & 83.1 & 5.7 & 9.9 & 1.3 \\
\hline
\end{tabular}

Source: CEO questionnaire. Gregory et al., 2000. IFC Report, Table 5.3, p.48

to 1998 , the percentages for all other sources of financing including loans from SOBs and credit unions, bonds and informal channels, fell over this period. The fact that private firms had to rely more on self-financing during the late 1990s suggests there were increased difficulties for private firms in obtaining formal sources of financing over this period.

Third, there are variations across regions in terms of private firms' access to loans from formal sources. For example, a relatively high percentage of firms in Mianyang obtained loans from SOBs, and lesser percentages from Wenzhou, Chengdu and Shunde. There were only a small number of private firms who obtained loans from SOBs in Beijing which has the highest proportion of firms that relied on self-financing ( 45 per cent). Credit unions were quite active in Mianyang, Deyang and Shunde. Informal channels for financing still played relatively important roles in all the surveyed cities especially in Beijing. There was no financing from foreign sources for the surveyed firms. The results seem to indicate that the more firms can rely on formal sources of financing, the less they depend on self-financing.

Finally, the results by firm size suggest that the larger the firm, the less it depends on self-financing and informal financing, and the more it relies on formal channels of financing and issurance of shares on the market.

Discussions of the financial position of the sample firms should be linked to the issues of enterprise arrears, which is a problem for private firms in China. Although the firm and CEO questionnaires did not collect information on the size of the arrears owed to a firm, interviews with CEOs revealed that arrears were common among the sample firms and had serious 


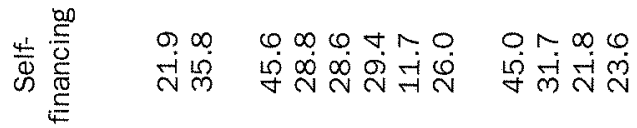

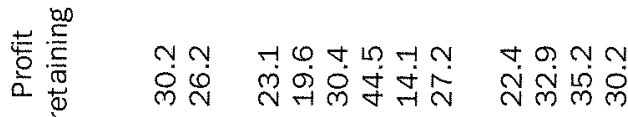

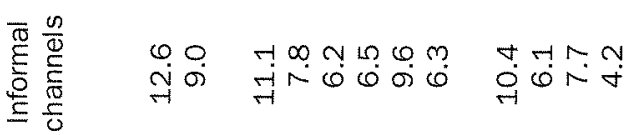

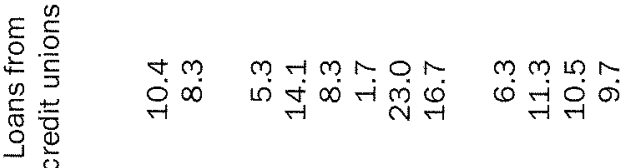

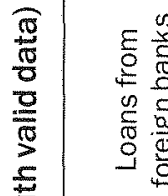

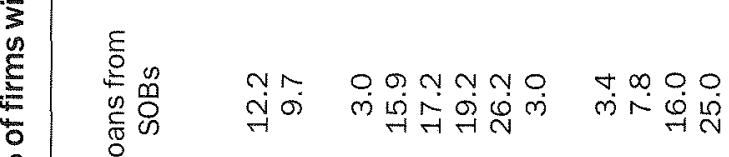

요

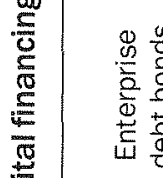

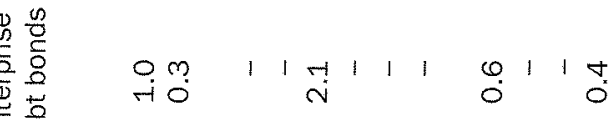

$0 \stackrel{0}{0}$

0
0
0

언

के

i⿱

or

正造

을 웅

ว

$\infty$
$\xi$

$\leqslant \frac{7}{0}$

잉

(1)

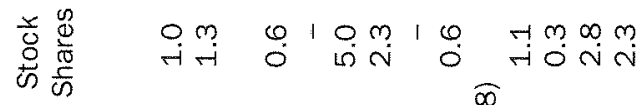


consequences. In the worst case, a firm could never get its sales proceeds back and could be dragged to bankruptcy. For example, a new firm in Beijing did not get back its first sales proceeds of 300,000 yuan and went bankrupt.

However, contrary to common belief, while it was common for a firm not to receive its sales revenue on time, it usually could get back all its due payments in the longer run. This type of arrears could take two forms. In the first form, the debtor did not promise a timetable for repayment, and paid the creditor by instalments, the frequency and size of which depended on how frequently the latter came to urge payment. In the other form, the debtor gave the creditor a money order that was cashable in three to six months. Since there is usually a grace period of three months after the goods are delivered, this means that the creditor can only get paid after six to nine months. This latter form was only adopted by large firms.

The ultimate reason for the rise of enterprise arrears is the lack of serious law enforcement on violations of contract. The lack of law enforcement inevitably creates free-riding behaviour which is not costless. The creditor can always go to court to sue the debtor, and this constitutes a major cost to the debtor. The debtor will usually lose this kind of lawsuit in the courts. If the creditor wins, it must face a weakness of the Chinese judiciary system, the lack of strict enforcement of the courts' verdicts. However, law enforcement has been improving in recent years, and debtors have to incur major costs in order to escape enforcement, usually by hiding their properties away, or in the worst case, escaping to other places. Therefore, the cost of playing with the legal system is high. Then, why are enterprise arrears still so common?

A standard theory concerning enterprise arrears in China is that they arise as a result of the bad performance of firms, especially the SOEs. However, the research team found that bad performance was not the only reason, nor was it the major reason, for the rise of enterprise arrears. A major reason of enterprise arrears was the lack of liquidity amongst firms. Viewed from this perspective, arrears were used by firms to solve the liquidity problem.

If arrears were a result of bad performance, the amount of arrears in an economy would be larger in a period of economic contraction than in a period of economic expansion. This is because in the former period a firm's performance has usually deteriorated and in the latter period it has usually improved. However, in an empirical study on China's total amount of arrears in the last ten years, Gao (1998) found exactly the opposite result.

The existence of enterprise arrears certainly raises costs because it introduces an extra risk to business operations. However, under a tight liquidity constraint, enterprise arrears provide a substitute for bank loans. In addition, firms have learned to handle the risk created by weak law enforcement. The research team found that firms treated arrears as a business 
risk and priced it in negotiations with their customers. As a result, the economy reaches a sub-optimal equilibrium that builds in both the liquidity and weak law enforcement problems.

How is the free-riding problem resolved under this sub-optimal equilibrium? For large firms that have enough wealth and legal resources, personnel and connections, the equilibrium does not affect them. In the study, the research team frequently heard complaints from medium and small firms that large firms were more prone to defer their payments although they could easily get loans from the banks. For smaller firms, the freeriding problem is likely to affect farmers' behaviour. Small firms use small parts that are distributed by large trading companies. To reduce the risk, these trading companies ask their customers to pay cash. This places an effective check on small firms' free-riding behaviour. For medium-sized firms, the legal cost associated with deferment plays a more significant role in curbing their tendency to free-riding. Therefore, the stability of the equilibrium depends on how severe the large firms' free-riding problem is.

An indicator of a firm's financial position is the turnover rate of its working capital. The turnover rate is calculated as the ratio between a firm's sales in a year and its stock of working capital in the same year. Therefore, it measures the frequency of working capital circulation. ${ }^{1}$ The turnover rate can be determined by several factors. A more efficient firm would have a higher turnover rate. A firm operating in a market with severe enterprise arrears may have a lower turnover rate because it takes longer to get its payments back. Last, a firm with a tight liquidity constraint would tend to have a higher turnover rate in order to use its limited funds fully. In the following analysis, we will try to isolate the influence of the last factor. Table 5.3 shows the turnover rate of working capital for 1995 and 1998 by city.

The turnover rate on average was maintained at 5.26 from 1995 to 1998. This meant that on average, the sample firms rotated their working capital about every 2.3 months. In light of the complaints of enterprise arrears, this fast turnover rate was surprising. One possible explanation is that the sample firms were successful in handling the risk of deferred payments by the methods discussed in the last chapter. In addition, the high turnover rate could be a result of the sample firms' high efficiency or a result of a tight liquidity constraint. A conclusive explanation cannot be provided.

There were large differences among cities. From 1995 to 1998, the turnover rates in Chengdu and Deyang decreased, but did not change in Wenzhou, and increased in Beijing, Shunde, and Mianyang. It is safe to assume that firms were as efficient in 1998 as in 1995. In addition, Beijing, Shunde, and Mianyang certainly could not have had a greater improvement in enterprise arrears than in Wenzhou whose turnover rate did not change. Therefore, 
Table 5.3 Turnover rate of working capital: 1995 and 1998

\begin{tabular}{lrrrr}
\hline City & \multicolumn{2}{c}{1995} & \multicolumn{3}{c}{1998} \\
Beijing & 2.8 & $(22)$ & 5.3 & $(154)$ \\
Shunde & 4.8 & $(15)$ & 5.6 & $(25)$ \\
Chengdu & 6.7 & $(13)$ & 3.1 & $(38)$ \\
Wenzhou & 7.1 & $(20)$ & 7.1 & $(30)$ \\
Mianyang & 7.7 & $(11)$ & 9.1 & $(17)$ \\
Deyang & 1.0 & $(22)$ & 8.3 & $(35)$ \\
Total & 5.3 & $(103)$ & 5.3 & $(299)$ \\
\hline
\end{tabular}

Note: Turnover rate is defined as frequencles of yearly working capital rotation. The number of valid entries is listed in the parenthesis.

Source: Firm survey.

their increased turnover rates between the two years could only be explained by a tighter liquidity constraint. However, the decreased turnover rates in Chengdu and Deyang could be caused either by a worsened situation of enterprise arrears, or by a not so tight liquidity constraint.

The above analysis showed that the liquidity constraint was indeed a factor that affected the sample firms' working capital. This was evident from the CEO interviews. For example, one of the major reasons that firms were very cautious in selecting customers was to avoid the breakdown of their cash flow because the consequence was catastrophic.

Many firms operated on the initial capital raised by their shareholders. For example, a large garment company in Beijing started business in 1992 and caught the wave of the overheated demand and accumulated a considerable amount of wealth in a very short time. As a result, it did not use outside financing at all in its course of development. However, not all firms were as lucky as this one in striking a peak of the business cycle. For most firms, operating on shareholder-provided capital was hard. For example, a Beijing firm specializing in building Intranet for logistic firms had five shareholders and 5 million yuan of capital. However, to complete a project, it had to use its own money to buy computer equipment for the project as well as pay its employees. It could only be paid back after the project was finished. The 5 million yuan of its own capital was just enough to sustain its business. If the project failed, the firm would go bankrupt.

The lack of funds did not stop at the lack of liquidity. Firms that are in an expansion phase need outside sources to finance their investment. For example, a Shunde firm specialising in making porcelain equipment had grown very fast since its founding three years before. It invented a new set of equipment that could compete with the best product made in Italy, the 
world leader in the industry. To put this new technology into production, it needed 60 to 80 million yuan to construct a new building and buy new equipment. However, it was not possible to find this amount of money in the country. It then considered listing on the Hong Kong $\mathrm{H}$ share stockmarket. Even in capital-rich Wenzhou, sufficient finance for large projects is hard to obtain.

The Chinese economy at the time of the Survey was stranded by sluggish aggregate demand. At the time, the government's expansionary fiscal and monetary measures had not given a lift to the economy. In particular, although interest rates were lowered several times to below 4 per cent for one-year loans, there was still no sign of expansion in demand for credit. This sharply contrasted with the lack of capital in China's vibrant nonstate sector, and revealed structural problems in China's banking system.

\section{Access to formal loans}

In China, formal bank loans are controlled by the four major state commercial banks, the Industrial and Commercial Bank of China (ICBC), the Bank of China, the Construction Bank of China, and the Agricultural Bank of China $(\mathrm{ABC})$ as well as local rural and urban credit unions. The lending policies of these banks are tightly controlled by the central bank, with little flexibility left to the state commercial banks. While the ICBC plays a major role in providing credit to China's $S O E$ sector, $A B C$ plays a major role in the development of China's TVE sector. Before private firms were officially recognised in 1988, it was impossible for them to get formal loans. This was one of the major reasons for the emergence of the 'red hat' firms. In early 1998, the central bank lifted the credit cap on each commercial bank and asked them to be responsible for their own profits and losses. This was a good start for China to establish a truly commercial banking system. How friendly were the state commercial banks to private firms?

Table 5.4 presents some statistics of loan applications submitted by the sample firms to the four state banks in the last five years. Among the 500 firms providing a usable answer, 33 per cent have applied at least once for loans from the four banks. The total number of applications is 1247. Among them, 1029 succeeded, so the success rate is 83 per cent. The average size of the loan is 1.02 million yuan. The high success rate is in stark contrast to the low percentage of firms having ever made an application. Clearly, there was self-selection when firms decided whether to make a loan application. We will leave to a latter stage the discussion of the factors that determined this self-selection process, as well as whether a firm could get a loan.

We now turn to the geographical pattern of the distribution of the applications. In Beijing only 14 per cent of firms had made an application. 
In contrast, in Wenzhou the proportion was 70 per cent. Beijing also had the smallest number of times an application was made, and Wenzhou also had the largest. However, it was Deyang and not Beijing that had the lowest success rate. In addition, its average loan was relatively large. In contrast, Wenzhou's average loan size was quite small although it had the highest success rate. This shows that firms in Beijing that made an application were likely to be larger firms while those in Wenzhou were smaller.

Table 5.5 shows the loan applications by firm size. It is clear that both the percentages of firms making an application and the success rate increased as the firm size increased. For firms with no more than 50 employees, only 17 per cent of them ever made an application, but for firms with more than 500 employees, 83 per cent of them made an application. The success rate for the former group of firms was 76 per cent whereas it was 88 per cent for the latter group.

The average size of loan also increased with firm size, with one important exception. The exception was that firms with no more than 50 employees had much higher average loan size than the firms in the two higher size categories. How this exception came about needs further exploration. This size-related pattern of distribution shows that larger firms possessed significant advantages over smaller firms in terms of the probability of getting a formal bank loan.

The above statistics reveal several important factors that determine whether a firm can get a formal bank loan. For example, the availability of credit counts (firms in Wenzhou were more likely to get a loan), and firm size also counts. In what follows, we will present a more comprehensive discussion of these factors.

The first factor is that the bureaucratic process of making an application for a formal bank loan itself is very costly. Paperwork is a burden. Among 254 firms with usable answers, 70 per cent said that paperwork was a moderate or major obstacle to their application for a formal loan. Firms not only have to do the paperwork with the bank, but also with the office of notary public, the asset evaluation agency, and other related government agencies in order to enable them to use their assets as collateral. To complete this paperwork takes both time and money. It would be regarded quick if a loan could be issued in one month. However, many private firms need urgent money. In addition, they also tend to want to borrow short-term money which banks are reluctant to lend.

Finally, there are many 'under-the-table' constraints. For example, a firm without a good relationship with bank employees may have problems in getting a loan. Among 207 firms, 69 per cent said that not having a good relationship with the bank was a moderate or serious constraint to 
Table 5.4 Applications for formal loans by city

\begin{tabular}{lrrrccc}
\hline & $\begin{array}{c}\text { Number of } \\
\text { firms }\end{array}$ & $\begin{array}{c}\text { \% of } \\
\text { applied }\end{array}$ & $\begin{array}{c}\text { Times } \\
\text { applied }\end{array}$ & Number & $\begin{array}{c}\text { Successes } \\
\text { Ratio }\end{array}$ & Ave. size \\
Beijing & 273 & 14.3 & 188 & 165 & 0.88 & 1033.2 \\
Shunde & 42 & 52.4 & 140 & 126 & 0.90 & 1987.0 \\
Chengdu & 70 & 45.7 & 252 & 187 & 0.74 & 1035.0 \\
Wenzhou & 50 & 70.0 & 472 & 452 & 0.96 & 661.5 \\
Mianyang & 25 & 60.0 & 142 & 122 & 0.86 & 1775.1 \\
Deyang & 40 & 55.0 & 144 & 72 & 0.50 & 343.8 \\
Total & 500 & 33.0 & 1338 & 1124 & 0.84 & 1027.3 \\
\hline
\end{tabular}

Note: In 1,000 yuan. Gregory et al., 2000. IFC Report, Table 5.6, p.52

\section{Table 5.5 Loan applications by firm size}

\begin{tabular}{lrrrrrr}
\hline Size & $\begin{array}{c}\text { Number of } \\
\text { firms }\end{array}$ & $\begin{array}{c}\% \text { of } \\
\text { applied }\end{array}$ & $\begin{array}{l}\text { Times } \\
\text { applied }\end{array}$ & Number & $\begin{array}{c}\text { Successes } \\
\text { ratio }\end{array}$ & Ave. size \\
& & & & & & \\
$<51$ & 235 & 0.17 & 209 & 159 & 0.76 & 1048.1 \\
$51-100$ & 72 & 0.46 & 274 & 214 & 0.78 & 478.8 \\
$101-500$ & 82 & 0.63 & 449 & 391 & 0.87 & 634.5 \\
$>500$ & 29 & 0.83 & 227 & 199 & 0.88 & 2282.6 \\
\hline
\end{tabular}

Source: Firm survey.

Note: In 1,000 yuan. Gregory et al., 2000. IFC Report, Table 5.6, p.52

their ability to get a bank loan. Of course, there were regional differences. Only 20 per cent of the firms in Wenzhou shared this opinion, compared with 79 per cent in Deyang.

However, little can be read into the regional difference as it is not only caused by the different styles of the banks but can also arise as a result of the difference in the availability of credit. Nevertheless, the importance of a good relationship with the bank is obvious. Many firms are forced to create such a relationship (Box 5.1). Because of these extra costs, many firms, especially small firms, are put off even trying to apply for a bank loan.

The second factor is that many firms cannot provide the necessary collateral or find a guarantor for their loans. This was the most frequently quoted reason by the sample firms for not being able to get a bank loan. Guarantees provided by local governments and by firms to each other were common until two years ago. However, this kind of guarantee created serious problems. Government guarantee was a major reason for the soft-budget 
constraint problem in both public and private firms, especially those in semiurban and rural areas. For example, the provincial ACFIC in Sichuan Province organised a kind of loan scheme to provide guarantees for private firms a few years ago and could not recover the losses it made from the experiment.

Firm-to-firm guarantee in many cases led to disputes. The firm that provided the guarantee usually asked the firm that took the guarantee to deposit part of the loan obtained in its own account. However, this money was usually retained by the former as a service charge (Box 5.1). If the two firms could not sustain their relationship, this led to disputes. As a result, the central government has recently prohibited local governments from providing guarantees to their firms, and firm-to-firm guarantees have been discouraged by the central bank. Therefore, providing collateral has become the only way for almost all the firms to get a bank loan. Yet many firms do not have the capacity to provide adequate collateral.

Amongst 248 firms providing usable answers, 62 per cent regarded collateral as a moderate or major obstacle to their ability to get bank loans. However, there were large regional differences. In Wenzhou, only 32 per cent had that opinion. In contrast, 73 per cent in Beijing had such an opinion. Other cities fell in between. Since the requirement for collateral is uniform across the country, the regional differences were mainly a result of the different levels of wealth held by private owners in different regions. The contrast between Wenzhou and Beijing is not surprising.

The central bank requires that the amount of loans with collateral in a commercial bank have to be at least 70 per cent of its total volume of loans. In the survey, the research team found that various forms of collateral were accepted by the banks. These included land, buildings, houses, apartments, cashable saving instruments (savings certificates, government bonds, etc.), equipment, and sales contracts provided by credible buyers (buyer-guaranteed bank loans). However, real estate assets, i.e., land, houses, apartments, and other buildings were the most common, and in some cases, the only kind of collateral that a bank accepted. Equipment was frequently rejected as collateral because of its speciality. There were only a few cases of buyer-guaranteed bank loans. One involved a foreign trade company as the guarantor.

There are two key issues which are directly related to collateral loans. First, many private firms do not have their own land or buildings to use as collateral. Owners' houses or apartments could be used as collateral, but people are usually reluctant to put their shelters under risk. In addition, the value of their houses or apartments is usually small compared with the amount of loan they want. There are some impediments even when a private owner wants to use his house as collateral. In rural areas, a frequently observed phenomenon is that an owner only has the property rights of his house, 


\section{Box 5.1 Firm Y's journey to get a bank loan}

Firm $Y$, located in Beijing, specialises in the export of Beijing ducks to industrial countries. Its owner told the research team of a six-step procedure for getting a bank loan.

First, you need to find a bank that believes you have the repayment capacity. Besides the requirements asked by the bank, you have to have an extensive social and information network.

Second, after locating a bank, you have to meet with the bank's manager, vice manager in charge of your industry, vice manager in charge of corporations, and vice manager in charge of lending. Of course, you have to spend money and time on this.

Third, after you have met with the managers, you have to convince the lending committee that you have the right credentials to get a loan. The committee will not send people to your firm, but just make its decision based on the credentials you send them. Fourth, you have to meet with the lowest manager in charge of your loan in one of the bank's branches. He also has the power to stop your loan.

In the above four steps, you have already invested a considerable amount of money and time. Some officials may even ask to borrow from you a car or an apartment. However, the long-march to get a loan does not stop here.

Fifth, you have to find a firm that is willing to deposit its money in the bank that will provide you with the loan. This is required by the bank. However, no firm will do what you want for free. You have to pay extra interest to the firm in the amount that is comparable to the interest it will get from the bank. Of course, to find a firm that is willing to provide the savings, you also need to spend money.

Sixth, you have now entered the last step, to get a firm that is willing to provide you with a guarantee because you do not have enough collateral. No one wants to provide a guarantee for you for free. You have to lend part of the loan you get to the guarantor. However, do not ex pect that it will return the money to you.

You finally get the loan, but you have already spent part of it before you even begin to use it. In addition, the term of the loan is one year, and you have to worry about its payment by the end of the first half-year.

Source: Gregory et al., 2000. IFC Report, Box 5.2, p.56.

but not the rights of the land occupied by the house because the latter is owned by the village. Under such circumstances, the bank is reluctant to accept one's house as collateral. As a result, many firms cannot get loans because of the lack of transferable collateral.

It is noteworthy, however, that private firms have begun to acquire land use rights under terms ranging from 50 years to 70 years. This happens in all the cities covered by this study, but is more common in Wenzhou and Shunde. With land in hand, firms avoid the problem of the lack of collateral. Because only relatively large firms can afford to buy land, lending inevitably is biased against smaller firms. Therefore, the ability to afford collateral is one of the significant factors that has contributed to the size-related distribution presented in Table 5.5.

Second, even if a firm has adequate assets to put down as collateral, it is costly for it to get the necessary credentials regarding the value of the assets. 
Asset appraisal is usually delegated by the related government branch of land or real estate management to a commercial real estate appraisal firm. After the appraisal, firms have to register the assets with the government branches in charge. In both steps, firms have to pay.

Appendix Table 5.1 in this chapter shows the different types of fees a firm can incur in a province. These fees usually take a percentage out of the total value of the assets. If there is no cap to a fee, a firm could end up paying a huge sum for collateral credentials. For example, a firm in the province cited in the appendix had to pay more than 300 thousand yuan in order to get the collateral credentials for its 37 million yuan loan. In addition, firms are required to renew their asset registration by each loan on a yearly basis and have to pay the full or part of the registration fee annually. Last, in many cases, the base of the fee is the value of the property, giving the appraisal firm a big incentive to inflate the value of the property and creating a potential risk to the bank. Repeated and arbitrary fees have greatly reduced firms' incentive to apply for a loan.

The third factor that impedes a private firm's ability to get a formal bank loan, especially small firms, is the information asymmetry between the firm and the bank. The asymmetry can be caused by several factors. First, most private firms are small and cannot survive severe market fluctuations. Therefore, they have a larger risk of default than larger firms do. Second, private firms usually do not want to reveal their information to outsiders. A typical private firm has three kinds of accounting books- one for the owners, one for the tax bureau, and one for its customers, investors, and the bank. Therefore, the bank has a legitimate reason to question whether the records presented by a private firm really reflect its financial position. Third, information asymmetry can also be attributed to the bank's inability to collect and process information. Finally, the lack of clear ownership and management structures also poses constraints to borrowing. ${ }^{2}$

Risk management had just been introduced into China's banking system in 1999, and banks had not accumulated the necessary experience for handling it. Most importantly, bank employees lack the incentive to collect information because they are not rewarded for doing so. For example, the City Credit Union of Shunde has an office in every village. Through personal contacts, employees in each office know fairly well the firms in the village. But they do not bring the information obtained in these personal contacts into the formal process of loan approval because they will not be rewarded for successful lending, but will be severely punished for default.

The fourth impeding factor is the central bank's restrictive policies on bank lending, interest rate management, and loan defaults. ${ }^{3}$ Because of the policy issued by the central bank, a commercial bank has to be responsible 
for receiving the repayment of every loan; that is, it has to reach zero risk on its lending. To harden enforcement, the central bank requires each bank to implement a policy called 'responsibility to individuals' that requires each employee to be responsible for each loan that is issued. The research team learnt that in a major state bank, default of more than 50,000 yuan would be sufficient for the person in charge to be prosecuted. Such a zero risk policy has severely limited bank employees' incentive to initiate lending. To avoid personal risk, banks prefer to put their customers' savings into their accounts with the central bank, that pay a higher interest rate than the savings interest rate they pay their customers. This action makes sense in terms of generating profits without risk.

In addition to restrictive regulations on bank lending, the central bank also enforces a uniform interest rate on the state banks. This is currently at 3.73 per cent for a one-year loan. Credit union interest is allowed to be 50 per cent higher than the basic interest rate, and loans to medium and small firms are allowed to be 20 per cent higher. However, the research team found that the average interest rate on the informal financial market was 10 per cent for a one-year loan, or two and a half times the basic official interest rate. This large gap indicates that the market for formal loans is in serious disequilibrium.

The research team found that neither the state banks nor the credit unions were honouring the central bank's regulation with all their loans and were charging interest rates closer to the informal market rate. The average interest rate charged by the state banks was 7.9 per cent, and that of the credit unions 11.5 per cent. These rates, especially after taking into account differences in transaction costs, are comparable to the market rate (the difference is not statistically significant). The variation of the interest rates charged by the state banks was the smallest; the CV was only 0.36 . The variations of the interest rates charged by the credit unions and the informal market are comparable, being 0.76 and 0.74 respectively. Therefore, both the state banks and the credit unions are moving towards the informal market equilibrium, but the latter have gone further towards unifying with the informal market.

The rationale behind this movement is clear-financial institutions need to price the risk of loans, but the price of the risk is demonstrated by the informal market because its equilibrium is driven by market forces. Private firms are generally perceived as being more risky, because of their survival uncertainty and their reluctance to release internal financial information. Therefore, it is reasonable for the state banks and credit unions to charge a higher interest rate to them. The uniform interest rate set by the central bank ignores the different degrees of risk on loans to different group of customers. That is why the central bank rule is ignored by all the financial institutions. 
The following conclusions can be drawn about the problems of formal lending. First, the application procedure is too complicated and time consuming, deterring private firms from making an application in the first place. Second, the collateral requirement has severely limited a private firm's ability to get a formal bank loan. While the requirement is necessary in many circumstances, several government policies that impede a private firm's capacity to use its assets as collateral. Third, information asymmetry is a serious problem in banks' lending to private firms.

However, it seems that the last problem can be coped with by a flexible interest rate system that allows banks to price the risk associated with the information asymmetry. Banks and credit unions, to various degrees, have already followed the informal market in this. The uniform interest rate regime set by the central bank has not been honoured by the commercial banks and credit unions. It has been found that the two kinds of formal financial institutions have moved toward the informal market equilibrium.

\section{Other forms of private firms' financing}

While formal bank loans play an important role in private firms' finance, other forms of finance are more important. Among the sample firms with a usable answer to a question on their source of capital, 44 per cent used loans from the four state banks, 42 per cent used loans from credit unions, 49 per cent found finance in the informal market, 61 per cent used their retained profits, and 78 per cent used their own savings. In addition, 1.1 per cent and 0.5 per cent said they used issue of equity and enterprise bonds, respectively. None of them said they had ever used foreign capital.

\section{The informal market}

The informal market plays an important role in private firms' finance, especially for working capital. Lending in the informal market has several characteristics. First, it usually happens among friends or family members, who form a closely-knit network. Reputation is an important factor in social life within the network. This has two effects on informal lending. One is that the problem of information asymmetry is reduced considerably because members of the network know each other well. The other is that the risk of default is also reduced because members want to maintain their reputations. As a result, informal lending is usually made without collateral. This is one of its significant advantages over formal lending.

Second, informal lending is usually for short-term loans. To a large extent, this is caused by the tight liquidity constraint faced by each individual and also driven by high interest rates. However, making shortterm loans also reduces the risk of default. As a result, it is often observed 
that firms only use informal loans to buy materials for an order and pay them back after the order is settled.

Third, informal lending is more flexible than formal lending with regard to the terms of the loans. While formal loans are usually issued for a term of half a year or one year with no grace period, the term of an informal loan can vary from several days to a year and grace periods are allowed. Private firms only need money to fulfil a production cycle which can be as short as several days in some industries. Because orders are not stable, there is no need for continuous financing. In addition, borrowers may not be able to pay back loans in time because payments for orders have not been received in time. Grace periods then enable them to work through the difficulties. In fact, the rigidity of the term of the formal bank lending is a significant factor that deters a private firm from applying for a formal bank loan because default on a loan payment may lead to bankruptcy.

Finally, informal lending does not require much time for application. A private owner can get a loan from friends or family members in one day. This is important for a private firm to solve short-term liquidity problems.

Consequently, the informal financial market possesses significant advantages over the formal financial market in terms of convenience to private firms. In addition, there is a tendency for the formal financial market to match its interest rates to those of the informal market, reducing the disadvantage of the informal market in this aspect.

However, the informal financial market also has serious problems when its scope extends beyond friends and family members. Among them, default and cheating are the most prominent. On the one hand, people cannot resort to laws for protection because most loans do not have a written contract. On the other hand, government cannot effectively enforce regulations in the informal market. The CEO survey reveals that only 14 per cent of the CEOs wanted to use informal borrowing in the future, sharply contrasting with 49 per cent that had used informal borrowing in the past. This finding reflects a weakness of the informal financial market.

In the last few years, semi-formal financial institutions have emerged in rural areas. One of them was credit associations that were usually organised by county and township governments. They attracted savings by offering high interest rates and made loans to local firms. If these associations had been managed properly, they would have been a very effective substitute for some aspects of the informal market. However, they ran into serious problems, many related to the involvement of local governments.

One major problem was that these associations had accumulated a large amount of bad loans. Since the associations were managed by local governments, many loans were issued to the local TVEs that shared the soft 
budget problem with their state counterparts. This was the major reason for the bad loans. As the bad loans increased, a major crisis developed, as the associations' liquidity became a serious problem.

To avoid a crisis, the central government issued a decree to shut down all credit associations. Almost all the credit associations have now been closed and their debts taken over by local governments. However, the research team found in Wenzhou that its credit associations were still operating. Wenzhou has a long history of informal financial markets and had private banks in the 1980 s when government policy was more amiable. Its credit associations had less government influence, and their loans were issued to private firms whose budget constraints were tight. Their good record of management largely explained their survival. While the closedown of most of the credit associations is necessary to avoid a major crisis, the finding in Wenzhou has shown that semi-formal financial institutions are viable with good management. The vacuum created by the closedown has to be filled by new semi-formal institutions otherwise private firms resort to the informal market.

\section{The stockmarket}

The two stockmarkets in Shanghai and Shenzhen play only a very limited role in private firms' finance. ${ }^{4}$ Among the 628 sample firms, only three or four firms are listed on the stockmarket. However, 15 per cent of the CEOs expressed an intention to finance their business through the stockmarket. Nevertheless, the central government implements a strict quota system on the number of firms to be listed in each province, and SOEs have priority. To circumvent the restriction, some of the sample firms adopted a strategy called 'to borrow the shell for the egg', that is, to get listed by buying a listed firm. This was observed in Chengdu and Shunde.

Private firms are generally cautious in making the decision to list. The stockmarket can provide capital to a private firm, but also exposes it to the risk of being taken over by outsiders. In addition, many private firms are reluctant to reveal their internal information as required by the regulations on listed firms. This also reduces their incentives to list. As a result, a private firm may not want to be listed on the stockmarket unless it needs large amounts of long-term capital. This condition, however, is frequently met by firms that are experiencing fast growth.

Several regional stockmarkets have emerged for small and medium-sized firms in the last several years. These regional stockmarkets were recognised and managed by local governments, and many of them were running quite well and played a significant role in helping the local firms finance their growth. Regional stockmarkets were shut down by the central government in the process of restoring order to the financial market in recent years. 


\section{Box 5.2 Bank finance in Wenzhou}

Wenzhou Branches of the Agricultural Bank of China (WABC), Industrial and Commercial Bank of China (WICBC), Construction Bank of China (WCBC) are three of the four major state banks in Wenzhou City. The following is their story.

WABC now has 13 billion yuan in deposits and 7 billion yuan in loans, with the ratio of credit to deposits 55 per cent. In the 1980 s it had a deposit deficit. However, in recent years the deposit surplus has been growing.

Wenzhou is an experimental zone for interest rate system reform. The interest rates of loans to private firms are allowed to float. The highest monthly rate recorded was 1.92 per cent. That was in the late 1980 s. From 1998 , the floating rates for private firm loans were no longer applied. Now it is allowed to float slightly, only according to firms' creditworthiness. The normal rate is 0.56 per cent monthly, but for firms which have a good reputation a 0.4 per cent or 0.42 per cent monthly rate can be applied. Now the rate is basically flat between the state owned and private owned enterprises. For individual business it is 0.657 per cent per month. The current market rate is 1 1.5 per cent.

About 70 per cent of the WABC credit is extended to private firms. This is an exception from the usual case in other areas. The return rate is acceptable. Problem loans account for 10 per cent, which is far lower than the national average. WABC started to lend to private firms relatively early, at a time when it was not really legal or even semi-legal. Now the creditworthiness of private firms is better.

In Wenzhou, there are also Rural Credit Co-operatives that have eight billion yuan deposited and six billion credit. The same interest rates apply. But for local branches that are below county level, interest rates may float up to 50 per cent.

Other non-bank financlal organisations in Wenzhou include the Rural Funds or Financial Services. Admitted by the ministry of agriculture or the state committee of economic system reform, they have now become privately owned. Each absorbed one or less than one billion of deposit. Because their interest rate is high, they competed with WABC. Recently development has slowed down as they are considered less creditable and have a high risk.

WICBC: All banks in Wenzhou City have a total of 70 billion yuan in deposits and 30 billion yuan in credits. In general there is no shortage of funds. Four categories of private firms exist using bank loans:

1. Firms in good situation and having high efficiency that do not have difficulties in finance. We can extend loans to them without guaratee

2. Firms operating in a stable situation that basically can solve their problems in finance.

3.\& 4. Firms in a worsening situation, or firms that have been newly established, and may have serious difficulties in gel

WCBC: Middle and small enterprises have difficulties in external finance. This is mainly due to the following problems.

1. How much are private property rights protected? This is still not very clear. This has hindered firms' development

2. Firms' management quality is still not satisfactory, particularly in accounting. Some firms were found to have three different account books for different purposes. Their credit grades were lowered by bank

3. Accountant and auditing services are usually rubber stamps. They provide certificates for money.

These increased the risk of bank credit, and result in the conservative operation of banks. 
In early 1999, a major state bank organised a nation-wide survey on fees collected from clients in the process of collateral appraisal and registration. Presented here is a table of 17 types of fees a firm may incur when assets are appraised and registered for collateral. Firms may need to pay up to six to seven fees. For example, a firm that wants to use its land as collateral needs to pay items $4,5,6,7,8$, and 16 (Refer to Appendix 5.1). The seven fees add up to between 0.9 per cent and 1.37 per cent according to the lower and upper boundaries. For the same item, several different and conflicting standards issued by different government branches at different levels are used. For example, for land appraisal fee, whilst one standard was issued in 1999 by the region's Bureau of Prices, at 0.12-0.16 per cent, another much higher standard of 0.32 per cent was issued in 1998 by the region's Bureau of Land Management, the government branch that collects the fee! In city $L$, an outdated standard of 0.16 0.32 per cent issued by the region's Bureau of Prices in 1998 was used.

Source: Gregory et al., 2000, IFC Report, Box 5.1, p.53

The survey demonstrated that private owners intended to use public offerings as a tool to improve internal management. When a private firm becomes large, morale issues arise amongst employees. As the size of the firm increases, employees aren't bonded by friendship. High and medium-level managers have more power and play a more important role in the firm's operation. Without shares in the company, it is easy for them to develop a feeling of being deprived. Private owners tried to facilitate share ownership by highlevel managers to overcome this problem.

However, when a manager wants to leave the firm, his shares have to be cashed out, and the firm incurs a loss and sometimes encounters a liquidity problem. For example, a Beijing firm owner gave a vice president 1 million yuan of shares when the latter joined the firm. However, he left the firm in only half a year, and the owner had to cash out his shares.

In Shunde, the owner of firm J, introduced in Box 4.1, wanted to keep employees by selling them shares. However, only a few employees bought shares. Because the shares could not be circulated outside the firm, their values were severely diluted. In the end, the owner had to buy back the shares already sold. He expressed a plan to get his firm listed if policies allow him to do so. His intention was not to get capital, but to improve his internal management. The morale problem is more acute in high-tech firms because they rely more on the human capital of their employees. A software company in Beijing decided to list on the stockmarket just for the purpose of solving its internal incentive problem.

\section{Overseas financing}

Overseas financing plays a limited role for sample firms. However, this limited role is increasing. The CEO survey found that 23 per cent of the firms wanted to enter joint ventures with foreign firms in order to get 
capital in the future, and 11 per cent expressed their willingness to borrow from foreign banks. Currently, Hong Kong plays a significant role in providing credit to mainland firms. For example, MD in Shunde was first listed in the Hong Kong stockmarket as $\mathrm{H}$ shares before it was listed in Shenzhen as A shares. It also borrowed foreign money through its subsidiary in Hong Kong when the anti-inflationary measures were at their peak in 1995. Some fast growing firms in Shunde were also considering being listed in Hong Kong as $\mathrm{H}$ shares. However, financing through Hong Kong is not limited to Shunde. The research team found that a firm in Chengdu was also listed in Hong Kong as $\mathrm{H}$ shares.

To a large extent, the limited role of overseas financing can be attributed to China's restrictions on foreign banks' operation in its territory. Right now, foreign banks are only allowed to have an operating office in Pudong, Shanghai. Only recently have they been allowed to issue renminbi denominated loans. In addition, renminbi is not a fully convertible currency. As a result, it is hard for a firm to repay a foreign currency denominated loan if it does not export. ${ }^{5}$

One way for a firm to use a foreign currency denominated loan is to get the central government's approval for loan to be taken into the country's foreign reserve management plan. Then the firm can get foreign currency by exchanging its renminbi with the State Bureau of Foreign Reserve Management. However, since it uses the country's foreign reserve, it is very hard to obtain approval for this method even for a SOE, not to mention a private firm. Finally, even if they can, private firms may not want to use foreign currency denominated loans because of the exchange rate risk.

\section{Reforming the financial system}

The financial system is the sector that has been subjected to the least reform in China so far. However, it is also a sector in which there has been considerable spontaneous testing of reforms, especially in the rural areas. China has a long history of informal financial institutions. In the reform period, voluntary co-ops, semi-formal credit unions, private banks, and local stockmarkets have also been tried out at the local level, without any being sanctioned by the central government. In this subsection, we present a discussion of possible ways to reform the financial system to accommodate the development of private firms.

The state banks are private firms' preferred source of loans. The CEO survey shows that 62 per cent of the firms wanted to borrow from the state banks in the future although they had a lot of complaints about them. To accommodate the demand of the private firms, the state banking system should take several reforms. First, lending management should be made 
flexible to accommodate risk management. The current policy of zero risk lending is not practical because doing business means taking risk. There is no business without risk.

The zero risk management should be replaced by portfolio management. By portfolio management, banks and employees are evaluated by performance on a certain amount of resources allocated to them. They can lose one or two loans, but so long as they maintain a profit for their total portfolio, they should not be punished. However, risk management requires each bank to invest heavily to improve its employees' human capital as well as to import advanced management techniques from developed countries. This is a major task for any state bank.

Second, related to risk management, banks should be allowed more discretion in deciding the interest rate. Although a very high interest rate hurts the economy by increasing the cost of borrowing, an interest rate below the market is a source of moral hazard. China has witnessed this with the soft budget problem when low interest rates led to a serious waste of resources. Giving banks more discretion does not necessarily mean complete freeing of the interest rate, but banks should be allowed enough room to price the different risks that their different groups of clients possess.

Third, while the collateral requirement is necessary, there would be value for private firms in extending the scope of unsecured loans. Can this be done without increasing moral hazard in ways that cannot be justified? In the study, it was found that large firms were granted non-collateral loans although they could also afford collateral. It is not clear how small and medium firms can get non-collateral loans. In Shanghai, Minsheng Bank is working with local entrepreneurs to create a guarantee fund. The local government put seed money into the fund, and firms have to contribute to the fund in order to get a guaranteed loan from the bank. A firm's contribution to the fund cannot be lower than 30 per cent of the amount of the loan it takes. The fund is managed jointly by the bank and the member firms and is running quite well. Therefore, firm-managed guarantee funds may help overcome small and medium firms' financing problems.

In Chengdu, the provincial government is in the process of preparing to set up a guarantee fund for lending to private firms under the scheme initiated by SETC. Apart from firms' contributions, governments also inject a certain proportion of capital into the fund, making the lending to the private sector based on 1:3 (three yuan can be leant on the basis of one yuan in the fund). However, there are management concerns about such schemes. Since such schemes will be implemented nation-wide, it is important to conduct some experiments in some areas before they extended across the nation. 
One of the reasons that the current expansionary measures aimed at boosting the domestic economy have had only limited effects is that the most dynamic sector, the non-state sector, cannot benefit much from these measures. This can be amply demonstrated with the stagnant nature of private sector borrowing for investment in recent years. Because of banks' reluctance to lend to private firms, lowering the interest rate has little effect on their borrowing behaviour. The reforms proposed above will remove the structural barriers faced by private firms and help the expansionary measures to have an impact on the economy.

Concurrent with the reforms in the state banking system, formal or semi-formal financial institutions outside the state realm should also be allowed. Right now, these have been eliminated, leaving only the informal financial market. The economy does need such financial institutions to function but to avoid past problems, private banks are a better choice in terms of supervision and management. On the management side, private banks have hardened their budget constraints and are responsible for their own performance. On the supervision side, private banks can be included in the same supervision network designated for the state commercial banks.

Currently, China has only one state-recognised private bank, Minsheng Bank. It is not private in terms of the word's true meaning because its 50 or so shareholders are all state-owned corporations. The introduction of private banks will increase competition in the financial sector and improve its efficiency. However, this would require the central bank to improve its supervision to accommodate numerous small banks should they be allowed to exist. On this aspect, international experience in setting up private banks and bank supervision and regulation will provide valuable help.

Finally, China should seriously consider giving private firms a platform for them to acquire non-bank equity. The two national stockmarkets should be more accommodating to private firms by treating them more equally alongside SOEs. In addition, the admission criteria should be more performance-oriented than needs-oriented. However, to rely on the two national stockmarkets will not solve the problem faced by numerous small and medium-sized firms. The feasibility of integrated regional stockmarkets should be explored. 


\section{Notes}

1. Caution needs to be taken in this calculation since increase (decrease) in turnover may be due to the changes in the sample structure in favour of industries that have higher (lower) turnover. The data provided here really reflect the average in the sample.

2. It was relatively easy for many former TVEs to get funding from banks since local governments provided some kinds of guarantees for borrowing. Banks would be more cautious towards those firms who have been converted from TVEs to private firms with the knowledge that these firms are no longer supported by local governments.

3. See Appendix table 5.1.

4. Domestic investors are restricted to the A share markets, B share markets are exclusively for foreign investors. Foreign investors can also invest in Chinese firms through $\mathrm{H}$ shares listed in Hong Kong. N shares listed on the New York Stock Exchange and Red Chip stocks listed in Hong Kong, which are Hong Kong firms with most of their cash flows derived from mainland Chinese operations and are essentially considered Chinese stocks by the market (Hasenstab 1999:139).

5. Even a firm that exports cannot retain foreign currencies if it does not have the right. 


\section{Appendix 5.1 Central Bank policies towards management of bank loans}

In the General Lending Rules issued by the central bank in 1996, there are stipulations regarding loan defaults.

Article 42: Establishment and improvement of Credit Responsibility System: Loan management sections at various levels shall delegate loan management responsibility at each stage to section, position and individual. Responsibility at different levels shall be clearly defined.

Article 65: Any responsible person of the lender who acts in breach of the Rules shall be disciplined and fined; anyone who engages in serious or repeated violations shall be dismissed from the working position and removed from his or her job qualification, and criminal procedures shall be followed if such violations brought serious losses or constituted economic crimes.

(The above is directly quoted except for several small language improvements) from the translation provided in General Lending Rules, a book published by Xinan Finance and Economics University Press, 1996) 


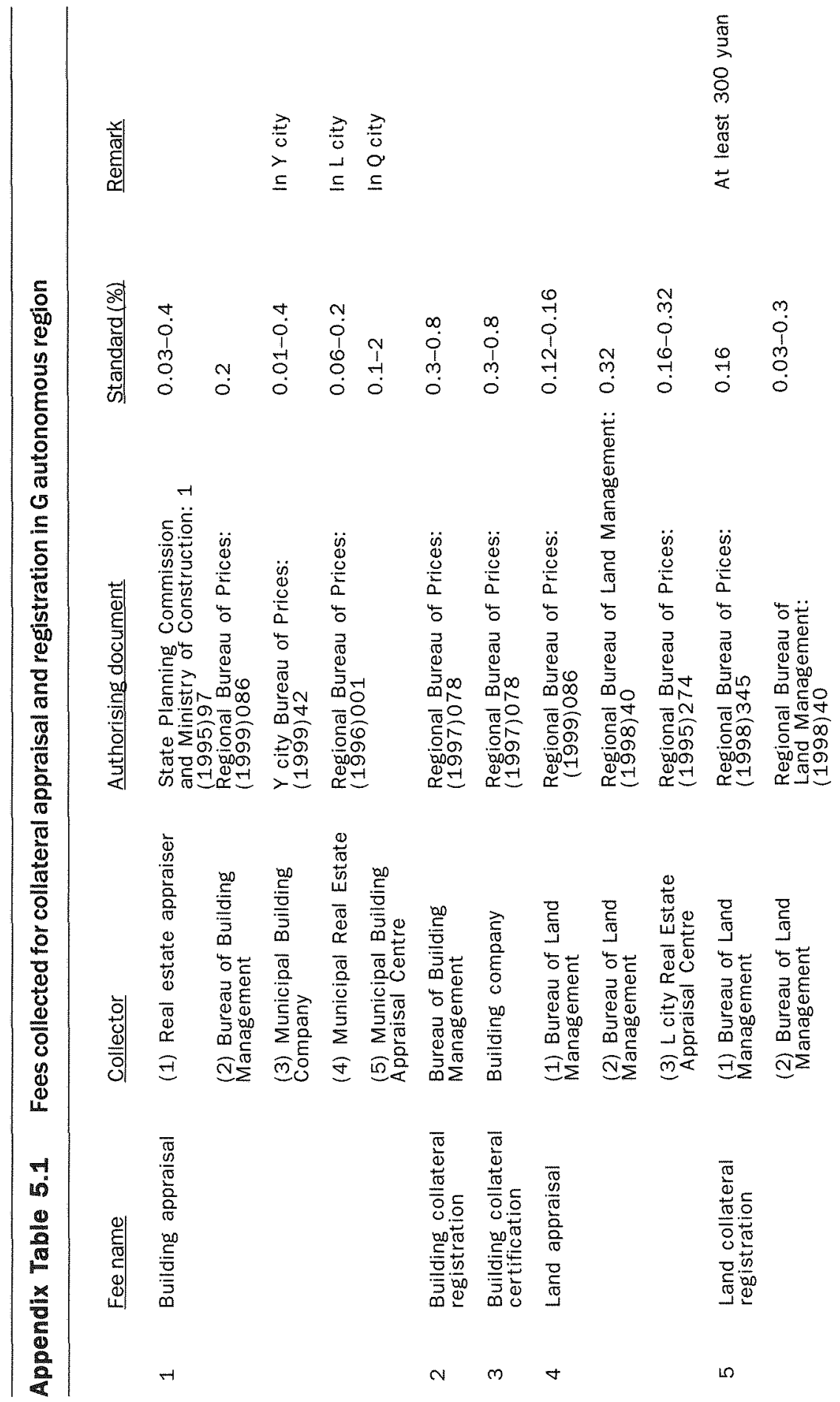


Finance

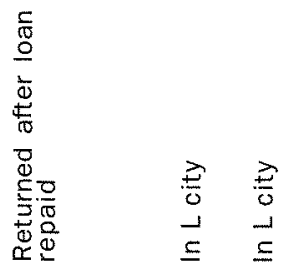

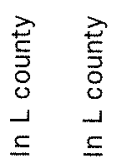

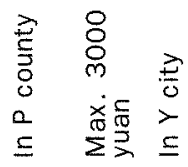

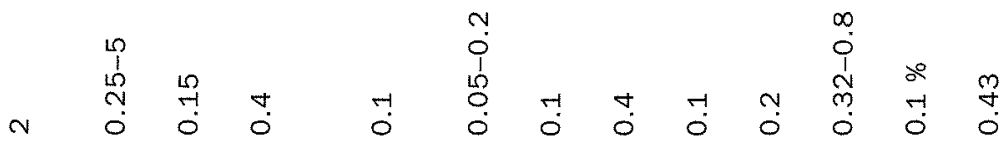

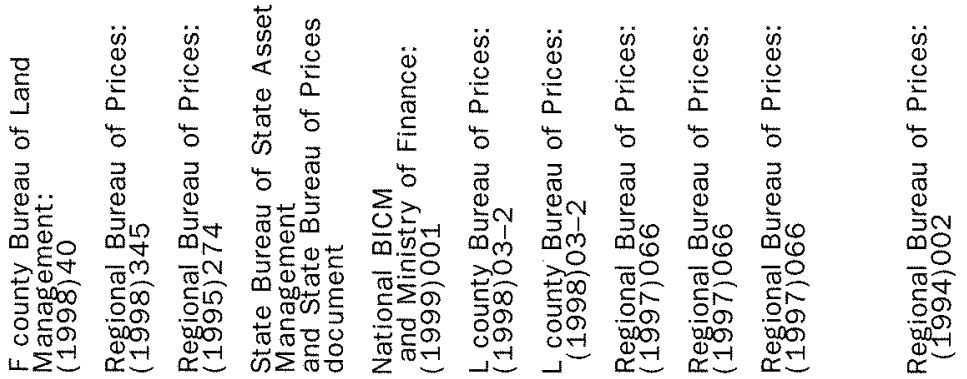

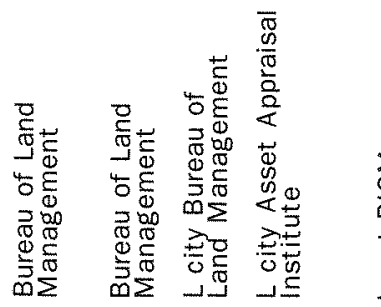

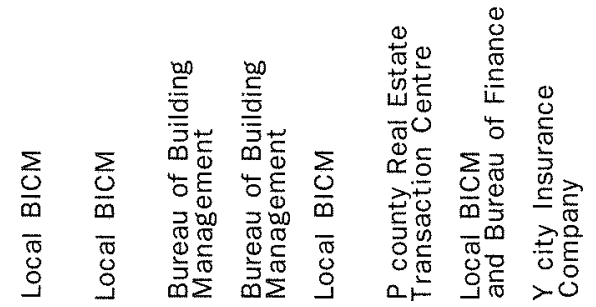

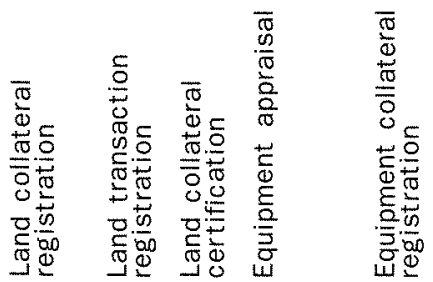
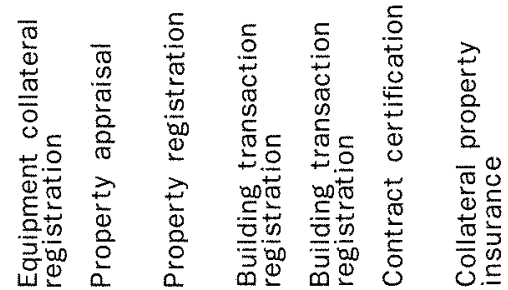

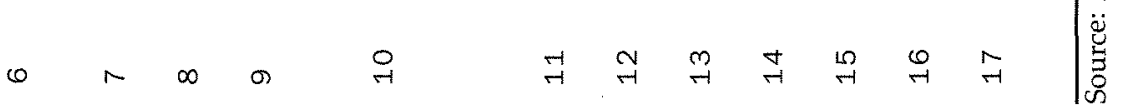




\section{6}

\section{Taxation}

In 1994, China began to implement a new system of taxation, based on a clear destination between central and local taxes. This chapter presents a description of this new taxation system and its impact on private firms. It also analyses the regional differences in the implementation of the new system, and the effects of taxation and fees on private firms. The new system gives local governments considerable discretion in setting taxation policies in their own jurisdictions. As a result, large regional variations have emerged. In addition, a large chunk of a local government's revenue comes from fees rather than taxes. In some cases, a small city may have as many as 300 kinds of fees, accounting for more than 60 per cent of the city's annual revenue (Ren, 1999). One major problem with the fees is their irregularity, which has attracted a lot of complaints and criticism from enterprises.

\section{China's new taxation system}

Before 1994, China had a revenue contracting system to define the relationship between the central and local governments. Under this system, a province handed over a fixed amount of taxes to the central government and retained the rest. This gave the local governments large incentives to increase their revenues. Although the amount of taxes handed over to the central government had to increase by a fixed percentage each year, the central government's share in the nation's total tax revenues declined sharply to only 11 per cent by 1993 . The new taxation system was designed to reverse this trend as well as to define a stable financial relationship between the central and local governments.

The new system requires the central government and each local government to collect their own specific taxes. As a result, the new system has been called fenshuizhi, or 'separate taxation system'. Currently, the central government collects 75 per cent of the value-added tax, special consumption taxes (on alcohol and tobacco products), and corporate income tax of firms owned directly by the central government.

A provincial government receives and collects 25 per cent of the valueadded tax, sales tax, personal income tax, corporate income tax of firms that 
are not owned by the central government, agricultural taxes, property tax, and other smaller taxes. The new system sets a clear distinction between central and local taxes. In addition, it has unified many taxes and reduced the number of taxes to only 15 , simplifying tax collection and saving resources.

The new system has achieved the goal of increasing the central government's share in the nation's total revenue. This is because the two largest taxes, valueadded and special consumption taxes, are overwhelmingly controlled by the central government. However, it has also led to new problems.

Decreased shares have caused large complaints from local governments. The central and western provinces are especially discontented because initial promises on transfers from the central government have not been met.

Each province was initially assigned a tax quota or revenue contribution with an annual growth rate. Although it was officially abolished, it has still been applied in many provinces and lower localities. The existence of a quota has placed a heavy pressure on local governments and ultimately on enterprises.

And most importantly, the new system has introduced a tension between a unitary state and a decentralised financial system. By law, only the central government can decide on taxation policies. With a huge territory and tremendous regional variations, a centralised taxation policy will not be effective in every province. In addition, there is a mismatch between taxation rights, and government resources and jurisdiction capacities. For example, the local branches of the central tax bureau collect the central taxes.

However, a case of tax evasion has to be taken up by a local prosecutor and tried in a local court, both of which do not have enough incentive to look after the central government's interests. Apart from that, the collection of local taxes is centralised to the provincial tax bureau. But the latter do not have enough capacity to collect the taxes and have to rely on local governments to fulfil the task. In poorer regions, local governments become the tax collector for the tax bureau (Yao, 1999).

Local governments' lack of the right to set their own taxes has been cited as an important reason for the proliferation of fees. Local governments are running on tight budgets. Yet, without the right to set their own taxes, they cannot use taxation to increase their revenue. However, the law does not forbid them to collect new fees. In addition, setting a new fee does not need to get the approval of the local legislators because it can be done as a government directive. One of the intentions of centralising tax legislation to control irregularities among local governments. In fact, centralisation has had exactly the opposite effect.

The centralisation of tax legislation itself is eroded by the central government's consent to local discretion in setting the rates of specific local taxes. The Survey revealed that each of the four cities covered in the first phase 
has the right to set the rates of the local taxes attached to the central taxes. These attached taxes are levied as a proportion to the total amount of the central taxes. However, many localities do not stop at the attached taxes, but set different tax rates on other local taxes. The tolerance of the central government is its effective consent to local tax legislative rights.

\section{Problems in the implementation of the current taxation system}

There are problems in the implementation of China's new tax system, and they have a specific impact on the private sector.

First, the progressive quota system has been set unrealistically in relation to the rate of economic growth. For example, Shunde is asked to increase its tax revenue by 10 per cent every year. This high growth rate puts great pressure on the Shunde government to enlarge its tax capacity. The group of firms hit most are those designated as small taxpayers who pay a fixed amount of taxes. Under the pressure of the growing quota, they are required to pay more taxes every year regardless of their actual performance. At the national level, to fulfil the national tax revenue target for 1998, many firms were forced to start paying their taxes for 1999 at the end of 1998.

Second, although the effective tax burden in China is not high compared with other developing countries, the design of some types of taxes is problematic. For example, the rate of the VAT is 17 per cent. The VAT does not allow a firm to account for its investments as a cost ${ }^{1}$. This measure greatly discourages firms' technological progress.

In addition, there was a local tax called an adjustment tax on capital investment. Its purpose was to curb inflation by discouraging investment in certain areas. It was a local tax, therefore its rate varied from place to place. Joint ventures and foreign firms were exempted from this tax. As a result, many domestic firms tried to find foreign partners when they decided to make major investments. This element of the system has been eliminated by the central government recently, on the grounds that taxation should aim at supporting strong long-term economic performance, rather than at deflationary objectives.

Third, the law governing VAT forbids small taxpayers from receiving VAT receipts. As a result, small firms have difficulties in doing business with larger customers who need the VAT receipts for their VAT deductions. The central tax bureau issued a directive in 1994 to allow a county-level tax bureau to issue VAT receipts on behalf of small taxpayers to its customers. However, a small taxpayer can only get this privilege with the approval of the local tax bureau. Therefore, the transaction cost of getting the VAT receipts is high. As a result, most small taxpayers prefer buying the receipts from large firms that cannot use up all their receipts. Because the transfer of VAT receipts is illegal, many small taxpayers have difficulty in finding a large firm that is willing to sell their VAT receipts, so their competitive capacities are limited. 
Fourth, the timing of the collection of the VAT does not match a firm's cash flow, often pushing the firm into a liquidity problem. Under current practices, the tax has to be collected at the time when a firm provides its VAT receipts to its buyer. However, because of the existence of arrears, the firm may not be able to get its payment back for some time. Even when there are no enterprise arrears, there is a grace period of three months for a firm's customer to pay. In the extreme case, the firm has to borrow money. A CEO from a fairly large private firm in Beijing forcefully pointed out this difficulty to the research team.

A way to solve the problem is for the firm to ask its customer to give it a grace period for providing the VAT receipts. However, this method only works if the customer maintains relatively good liquidity.

Fifth, tax and fee collections are still subjected to the arbitrary judgments of government officials. The weak supervision of local governments is the first factor to be blamed. However, the blame does not stop at the local level. Arbitrary judgments also arise as a result of local governments' adjustments to local conditions when they lack legalised local tax rights. For example, in more developed areas, several kinds of agricultural taxes such as a tax on special agricultural and forest products have very small tax bases, so the costs of collecting these taxes are very high. It is therefore understandable that local governments give up the collection of these taxes.

This is also true for some small local taxes (for example, property tax in underdeveloped areas). In addition, arbitrary behaviour is also encouraged by the laws governing business operations. For example, it is stipulated by law that a firm should be fined 10,000 to 50,000 yuan if it fails to undertake reregistration when its address is changed. This large range can also be found in other laws. It gives officials ample room for personal judgments.

Sixth, for private firms with a single owner or for partnerships, corporate income tax and personal income tax overlap each other. These two kinds of firm take unlimited responsibility for their liabilities. Therefore, the owners' income is not different from their firm's income. So the two kinds of income should be taxed jointly once. In fact, a getihu is only taxed once. The difference between a getih $u$ and a sole ownership firm is that they have different numbers of employees.

Finally, the proliferation of fees has damaged the integrity of China's taxation system. In addition to increasing firms' burdens, fees cause unnecessary uncertainty because of their irregularity. In the CEO Survey, 73 per cent of the firms which provided usable answers said that fees were a moderate or serious hindrance to their business operation. The most frequent complaint was that the fees were unpredictable and overlapping with each other. As cited in the last subsection, the proliferation of fees is closely related to local governments' lack of legislative power in setting local taxes. Currently, it is a major endeavour for the central government to bring the fees under control. 
One measure proposed is to convert most of the fees into taxes. However, without solving the tension between a decentralised financial system and a centralised tax system, the attempt of converting fees into taxes will be futile because uniform taxes cannot suit every locality's economic conditions and only induce local governments to use fees to fill the gap. In addition, the persistence of fees is also closely linked to the growing size of the local governments. To finance the enlarged government, local chief officials have to give tacit consent for their subordinates to set up and collect fees within their administrative spheres. That is why firms feel that many fees are overlapping with each other. Without genuine government reform, it will be difficult to cut down the size of the fees.

\section{The distribution of tax burden}

In China, government income can be grouped into three categories; budgetary, extra-budgetary, and non-budgetary. Budgetary income mainly comprises taxes. In 1997, tax income consisted of 9.3 per cent of China's GDP. Extra-budgetary income includes local government surcharges, user fees of public utilities and services, and profits of state firms. Non-budgetary income comprises extra fees and local government bonds. In 1996, extra-budgetary income was 40 per cent of budgetary income (Yang, 1998). However, there is no statistic showing the exact size of the non-budgetary income. According to Yang's estimate, this portion was about the same size as the budgetary income. The overall tax and fee burden in China is about 25 per cent of its GDP. This puts China in the upper tier of the developing countries in terms of tax burden.

The tax contribution of the private sector to total state tax revenue has increased steadily over the past ten years. As shown in Table 6.2, the private sector's contribution to total state revenue increased from 2.6 per cent in 1986 to 8 per cent in 1997 . If the contribution of shareholding companies is added to this, the share of total revenue was 12.8 per cent in 1997.

In firms covered by the sample and providing usable data, on average, taxes represented 6.6 per cent of a firm's sales, and fees accounted for another 3.1 per cent. This makes the overall tax burden 9.7 per cent of sales. The data gathered from the Survey show that 302 firms reported their VAT for 1998 with the average tax being 904,900 yuan. Calculated on the basis of tax due, the average tax should be 1,111,900 yuan per firm. The tax due was calculated based on the VAT rate of 17 per cent over value-added for firms with a sales volume larger than 1 million yuan and the VAT rate of 6 per cent over sales volume for firms with a sales volume under 1 million. The differential standards for different size firms are set by the state tax code. Therefore, an average firm paid 18.6 per cent less than the amount of VAT due in 1998, equivalent to 0.9 per cent of the sales volume of the average firm. The differences between tax due and actual payment of VAT by firm size are also large (Table 6.2). 
Two hundred and seventeen firms reported their corporate income tax for 1998. On average, a firm paid 423,000 yuan in income tax. At the rate of 33 per cent based on data provided by 103 firms, the average income tax should have been 3.4 million yuan. The differences between tax due and actual payment of corporate income taxes by firm size are large (Table 6.2). The differences can be partly attributed to various legal tax breaks firms enjoy. Smaller firms pay more taxes than they should, while larger firms pay less.

The Survey results show that differently sized firms have different attitudes towards the tax burden. While the three other groups of firms had a percentage between 64-66 per cent, 78 per cent of the firms with 51 to 100 employees regarded taxes to be moderately or very high. Did this distribution match the real tax burdens of these four groups of firms? The firm Survey shows that in 1998 , the percentages of taxes in total sales for the four groups of firms, from smallest to the largest, were 6.2 per cent, 7.8 per cent, 6.9 per cent, and 5.7 per cent, respectively. This matches the intensity of complaints.

The reason that firms with no more than 50 employees had the lowest tax rate is that most of them are small taxpayers whose taxes are fixed quotas calculated by tax officials based on their estimated sales. Because firms tend to under-report their sales, their tax quotas were low. Starting with the group of firms with 51 to 100 employees, firms begin to qualify as regular taxpayers that pay taxes on a proportional basis.

Table 6.1 Tax contribution of the private sector: 1986-97 (billion yuan)

Pure private firms National \& getihu*

\begin{tabular}{lrrrrc} 
Year & Total & Amount & Share (\%) & Amount & Share (\%) \\
1986 & 178.2 & 4.7 & 2.6 & - & - \\
1987 & 183.2 & 6.1 & 3.3 & - & - \\
1988 & 212.9 & 7.9 & 3.7 & - & - \\
1989 & 241.2 & 12.1 & 5.0 & - & - \\
1990 & 245.4 & 13.4 & 5.5 & - & - \\
1991 & 266.5 & 15.5 & 5.8 & - & - \\
1992 & 288.9 & 18.2 & 6.3 & - & - \\
1993 & 380.9 & 27.0 & 7.1 & 30.3 & 8.0 \\
1994 & 472.9 & 37.8 & 8.0 & 44.2 & 9.3 \\
1995 & 551.6 & 43.6 & 7.9 & 56.7 & 10.3 \\
1996 & 541.1 & 45.8 & 8.5 & 64.2 & 11.9 \\
1997 & 686.1 & 55.1 & 8.0 & 87.5 & 12.8 \\
\hline
\end{tabular}

Private, getihu and shareholding companies

Note: * it includes only private firms with single owner.

Source: Based on Taxation Yearbook of China: 1992-98. 
The decreasing tax burden with increased firm size could result from the greater leeway for larger firms to evade taxes, or from larger tax privileges. Tax privileges are more important. Almost all the tax reductions promised by the central and local governments are biased towards large firms. Since larger firms usually maintain better and more open accounting records, tax evasion is usually harder for them.

As an example of tax privileges, the central government stipulates that firms in high-tech industries (defined as firms that produce certified high-tech products) can be exempted from corporate income tax for three years, and after the initial three years, the income tax rate is only 15 per cent. In addition, firms with products that are designated as provincial new products can also get tax breaks. Only larger firms with certain technological capacity can qualify for these preferential treatments. As a result, larger firms have lower effective tax rates. For example, in Shunde in 1998, only 6 per cent of the benefits of tax privileges went to small sole-ownership private firms.

The size distribution of the complaints about excessive fees is more even than for taxes. Firms with 51 to 100 employees still had the highest percentage of 89 per cent, but the percentages of the other three groups of firms were distributed in the range from 67 to about 78 per cent. For 112 firms with valid data, the average fee rate was 3.1 per cent of sales volume. For the four groups of firms, from the smallest to the largest, the fee rates were, respectively, 4.8 per cent, 1.7 per cent, 2.4 per cent, and 1.9 per cent. Since many fees are collected on firms regardless of their size, the higher rate for the smallest firms makes sense. The differences among the three other groups are small. Therefore, it is paradoxical that not the smallest but the second smallest firms had the strongest complaints. One explanation is that members of the latter group of firms were describing their total burden of taxes and fees.

Table 6.2 Difference between tax due and actual payment by firm size $(1,000$ yuan $)$

\begin{tabular}{lrrrr}
\hline & \multicolumn{2}{c}{ VAT } & \multicolumn{2}{c}{ Income Tax } \\
Firm size & Difference & Firms & Difference & Firms \\
& & & & \\
$<51$ & -191.3 & 104 & 107.4 & 39 \\
$51-100$ & -788.3 & 31 & $-1,436.5$ & 23 \\
$101-500$ & 89.5 & 29 & $1,484.7$ & 28 \\
$>500$ & $17,986.6$ & 10 & $40,103.9$ & 10 \\
\hline
\end{tabular}

Source: From the survey data 
In terms of geographical distribution, the tax rates in 1998 were 5.9 per cent in Beijing, 11.8 per cent in Shunde, 5.6 per cent in Chengdu, 8.6 per cent in Wenzhou, 6.0 per cent in Mianyang, and 5.9 per cent in Deyang. The fee rates for the six cities, in the same order, were 4.0 per cent, 4.9 per cent, 2.1 per cent, 2.6 per cent, 1.3 per cent, and 2.9 per cent, respectively. Shunde had the highest tax and fee rate. It also had more firms complaining about high tax rates. The CEO Survey shows that 80 per cent of the firms in Shunde complained that tax rates were moderately, or very, high. However, the city with the lowest percentage of complaints was not Chengdu, but Wenzhou. Only 53.8 per cent of the firms in Wenzhou had the same complaints while the percentages in other cities were all over 60 per cent.

In terms of the intensity of the complaints about excessive fees, the order did not match that of the actual fee rates at all. The city that had the highest percentage of firms regarding fees as moderately or highly excessive was Deyang. An estimated 93 per cent of the firms in that city had a complaint. In addition, Mianyang had the lowest actual fee rate, but there were 87 per cent (second highest) of its firms had the complaint. This shows that firms' complaints on fees were not directed to the size of the fees, but rather to the ways that the fees were collected.

Regional differences in the tax burden can be created by two factors. One is the difference in tax rates; the other is the effectiveness of enforcement. Shunde was ranked high for both factors. Let us look at the first factor, examining the local attached taxes that are levied as percentages of the central taxes a firm pays. The central government allows local governments to use the attached taxes for local public services such as education, urban construction, transportation, military reserves, flood control, and other items that local governments think are necessary. The rate of all the taxes added together is 16 per cent in Shunde, and 14 per cent in Chengdu. However, both are high compared with a district in Shanghai where the rate is only 9 per cent. In particular, the added education tax is 11 per cent in Shunde, but only 3 per cent in Chengdu and Shanghai.

Another example is corporate and personal income taxes. They are 1 per cent and 0.2 per cent of a firm's sales, respectively in the district of Shanghai, but are 1.5 per cent and 0.3 per cent in Shunde. Chengdu implements the national standard of levying the income taxes based on the profit and income a private owner earns. Income is divided into three groups: less than 30,000 yuan, between 30,000 yuan and 100,000 yuan, and more than 100,000 yuan. The tax rates are 18 per cent, 27 per cent, and 33 per cent, respectively. China's income tax interval is not one year, but one month in most cases. For irregular income, tax is levied when the income is realised. Obviously, people will be taxed at an artificially high rate if they get their whole yearly income in one instalment.

In addition to regular taxes, Shunde also created a tax called a resource usage tax that is levied on land used by a firm. Many firms have purchased 60 to $70-$ 
year land use rights in the process of privatisation. To maintain township governments' revenue, the municipal government allowed them to levy the resource usage tax, levied at the high rate of 2.1 yuan $/ \mathrm{m}^{2}$ per month. For a medium-size firm with $10,000 \mathrm{~m}^{2}$ of land, the annual tax amounts to 249,600 yuan (Box 6.1).

Third, the Shunde government is consciously using high effective tax rates as a tool to change its industrial structure. The demand for changing its industrial structure comes from two sides. On the one hand, the Shunde government intends to upgrade the city's industrial structure from labourintensive to knowledge-intensive. After 15 years of development, Shunde has gradually lost its competitiveness in labour-intensive industries, but has gained the necessary physical and human capital to move to more capital and knowledge-oriented industries. On the other hand, people's demand for a better environment has increased with their income.

Therefore, it is a high priority for the municipal government to induce the closing of small and polluting firms. High tax rates force firms with small margins of value-added, usually firms in the traditional labour-intensive industries and small firms, to move out of the city or simply close. This policy seems to be working as the research found that a number of firms had moved to the neighbouring city of Zhongshan.

However, the adverse effects of high tax rates on small firms may create problems for the city, especially in the area of employment. Currently, small firms with sales volume less than 100 million yuan account for more than 60 per cent of the city's total workforce, although their output accounts for less than 40 per cent of the total. Although it is a right direction to provide a fair competitive environment for all firms, data provided by this study show that large firms have an advantage over small firms in terms of effective tax rates because of the tax privileges that only larger firms can obtain. Some measures have to be taken in order to provide small firms with a level playing field.

It is noteworthy that Shunde was the best among the cities covered in the first phase of the Survey in terms of arbitrary behaviour in tax and fee collections, although it had the highest tax and fee rates. This had much to do with the government reform carried out in Shunde in 1993. A detailed account of the reform will be presented in Chapter 10. Here we emphasise that the reform has greatly limited government officials' rent-seeking behaviour by eliminating many functional departments and constraining the powers of the remaining departments. In addition, the management of government income and expenditure is centralised. Any fees collected by any departments have to enter the centralised account, and departmental budgets are controlled by a single office. This measure has had a great effect in curbing rent-seeking behaviour. 
Other cities generally have not done as well as Shunde. In the CEO Survey, more incidences of arbitrary behaviour were found in other cities than in Shunde. For example, in Chengdu, the tax bureau suspected that a firm had been evading tax. It not only arrested the firm's owner, but also searched the firm and closed all its accounting records. In the course of these actions, the tax officials said: 'I can let a guy die if I say so!' It turned out that the firm did not evade tax. The tax bureau took the action only to punish the owner who had not shown enough respect to tax officials. The owner thus told the research team that it was a matter of 'life or death' whether a firm maintained a good relationship with the government.

In Chengdu, the behaviour of the city's technical standard inspection authority was also arbitrary. For example, by law a fee can be imposed only if the product inspected has defects. In order to impose the fee, the inspectors often exaggerated defects. To settle with the agency, firms often ended up making a lump-sum payment each time it sent an inspector. In Beijing, the research team learnt from local tax officials that there was enormous scope for personal

\section{Box 6.1 Firm S's local taxes and fees}

Firm $S$ is located in Shunde. Its main products are plastic tubes for road, sewage, and communication constructions. It was a township-owned firm before 1997, but has been privatised recently. The overall burden of taxes and fees is not large, only about 5 per cent of the firm's total sales revenue. However, it complained that there were too many kinds of local taxes and fees. Here is a list of its local taxes and fees (may not be complete).

- Local value added taxes (levied on the value of the VAT):

- Education: 11 per cent

- Urban construction: 5 per cent

- Flood control: 1.5 per cent

- Land usage tax: 2.08 yuan $/ \mathrm{m}^{2}$.month (the firm has $10,000 \mathrm{~m}^{2}$ )

- Street cleanup fee: 300 yuan/month

- Trash transportation fee: 300 yuan/quarter

- Crime control fee: 0.1 per cent of electricity usage (stopped in 1999)

- Temporary resident certificate for outside workers: 200 yuan per person per year

- Management fee for outside university graduates: 80 yuan per person per year plus one-time payment of 600 yuan.

Shunde is also the city that maintains the most intensive implementation of tax collection. To a large extent, its firms' high tax burden is related to its rigorous implementation of the tax system. This was emphasised by the local officials and confirmed by interviews with firms. The purposes of such rigorous implementation are several. First, it creates a relatively fair competitive environment for all the firms. In fact, this is one of the aims that the Shunde government sets for its government reform. Second, it responds to the progressive demand of the higher authority for Shunde to increase its tax revenue. 


\section{Box 6.2 Fees collection and government corruption}

Many firm managers complained about the unregulated government collection of fees and government corruption. Here are some examples.

a. The $X X$ township government formally employs 102 persons, when 50 would be enough. Moreover, it actually employs more than 400. Employees don't have many things to do, beyond reading newspapers and playing cards in working hours. The government budget of 4.5 million yuan is not enough even for the wage bill. The total annual expenditure exceeded 10 million. The additional funds came from selling land, fines, and fee collection. Each firm has to pay something. In addition, you have to dine government officers two or three times a month for no benefits. For normal business dealing with a government department you have to entertain them. These have been a heavy burden to firms (CG).

b. A main problem firms face is that government departments overuse their power to intervene in firms' business. Any government department, such as a bureau of labour administration, central and local taxation, urban programming, land administration, public security, industry and business administration, or environment protection, may come to a firm at any time for inspection. Officials try to find flaws in the firm's activity without providing any help. The labour bureau required that for each employee a firm had to pay a 20 yuan service fee per year to the bureau, but it provided service to firms and employees. The more people who are employed, the higher the charge. This is a penalty on providing employment. Our company pays a 4,000 yuan 'security fee' per year to the police station, but the police never take care of the firm's security problems. Recently a worker stole 40,000 yuan from the company and was reported to the police, but they said that the amount of money was too small to be registered. Even worse is that government officials ask for bribes and would make trouble for firms if they did not get what they sought (HDL).

c. Each time the firm develops a new product it has to pass an 'examine-andaccept' conference. It does not matter whether the quality of the product is good or not, you still have to give presents and entertain the examiners. The environment protection bureau charges 20 yuan for each machine for "exceeding the noise pollution standard', without any test of the noise. However, after entertaining the inspectors, all charges are exempted. Many government officers are of a low quality, poorly trained and poorly disciplined. (DL) 
discretion in deciding a firm's tax quotas or whether a firm be treated conveniently. In Wenzhou, many firms complained about the arbitrary fees. For example, the environmental protection office could go to a factory to measure the noise of its equipment. The intention of the office was to impose a fine on the factory. The factory owner then began to negotiate with the officials. It usually ended up with the owner paying the office a reduced amount of fine.

\section{Concluding remarks}

China's taxation system still needs major adjustments in order to solve the tension created by the decentralised income rights and centralised tax legislation. There are many unsolved problems in the implementation of the current taxation system. To solve these problems, China needs to take bold steps to improve the consistency and effectiveness of its laws, transform the role of its local governments, and strengthen the supervision of public servants. The differences found for the effective tax rates of firms of different sizes are caused by the firms' size-dependent capacities to get tax privileges. The regional differences in the effective tax rate are related to the degree of local government reforms as well as local governments' intention to use taxation as a tool to fulfil certain economic goals.

\section{Note}

1. There are three types of VAT in the world. One is production type that does not deduct capital investment from the VAT base. One is income type that deducts capital investment from the VAT base by distributing its value in its depreciation cycle. The last one is expenditure type that deducts capital investment as outlays are increased. Most industrial countries adopt the last type of VAT. China adopted the first type. 


\section{7}

\section{Internal governance}

This chapter discusses internal governance. We first present statistics on sample firms' ownership forms and discuss the benefits and costs of each form. It then discusses their internal governance structures, paying special attention to the issues that are unique to private firms. It also discusses governance issues in the context of industrial organisation. The focus then shifts to labour management and the relationship between the owner and the employees.

\section{Ownership forms}

Chinese law defines four forms of ownership: sole ownership; partnership; limited liability company; and limited liability shareholding company. Table 7.1 shows the distribution of the forms of ownership taken by the sample firms in 1998 . The questionnaire did not distinguish between limited liability and limited liability shareholding companies because they are the same in terms of the liability of shareholders. However, it asked whether a firm was listed in stock markets.

Among all of the 612 firms providing a usable answer, the percentages of sole ownership, partnership, limited liability, and public listing were, respectively, 40 per cent, 30 per cent, 28 per cent, and 0.5 per cent. Compared with the national data, there are more partnerships in the sample. ${ }^{1}$ There were regional differences. While Chengdu had a small percentage of sole ownership ( 25 per cent), the differences among the others' were relatively small. Beijing had the highest percentage of partnerships (38 per cent), Mianyang the lowest. Consistently, Beijing had the smallest percentage of limited liability companies. Chengdu had the highest percentage (59 per cent). Finally, two of the 3 firms that were publicly listed were based in Beijing; the other was in Mianyang.

Different ownership forms have different benefits and costs for a firm. Sole ownership has the disadvantage of $\mathbf{u}$ nlimited liability, but it also has certain benefits. The current law prohibits a single owner from registering the firm as 
Table 7.1 Ownership distribution of sample firms: 1998 (number of firms and \%)

\begin{tabular}{|c|c|c|c|c|c|c|c|c|c|}
\hline \multirow[b]{2}{*}{ City } & \multicolumn{3}{|c|}{ Sole ownership } & \multicolumn{2}{|c|}{ Partnership } & \multicolumn{2}{|c|}{$\begin{array}{l}\text { Limited } \\
\text { liability } \\
\text { company }\end{array}$} & \multicolumn{2}{|c|}{$\begin{array}{l}\text { Publicly } \\
\text { listed } \\
\text { company }\end{array}$} \\
\hline & Firms & Count & $\%$ & Count & $t \%$ & Count & $\%$ & Count & $t \%$ \\
\hline Beijing & 341 & 139 & 40.8 & 129 & 37.8 & 71 & 20.8 & 2 & 0.6 \\
\hline Shunde & 54 & 25 & 46.3 & 12 & 22.2 & 17 & 31.5 & - & \\
\hline Wenzhou & 87 & 30 & 34.5 & 26 & 29.9 & 31 & 35.6 & - & \\
\hline Chengdu & 51 & 13 & 25.5 & 8 & 15.7 & 30 & 58.8 & - & \\
\hline Mianyang & 28 & 16 & 57.1 & 3 & 10.7 & 8 & 28.6 & 1 & 3.6 \\
\hline Deyang & 51 & 25 & 49.0 & 8 & 15.7 & 18 & 35.3 & - & \\
\hline Total & 612 & 248 & 40.5 & 186 & 30.4 & 175 & 28.6 & 3 & 0.5 \\
\hline
\end{tabular}

Source: Firm survey.

a limited liability company. Therefore, an owner that did not want to have a partner would be better to register as a sole ownership firm. In addition, sole ownership makes management easier. If the firm is not large, this will be a big advantage for the firm. Sole ownership also has the advantage of not requiring a standard corporate account, which puts it under the state's supervision. This provides certain attractions, including in relation to tax evasion.

However, when the firm becomes large, single-owner management becomes difficult (see the next section for more discussion). In addition, if a firm is not registered as a corporation, it cannot call itself a company. Therefore, being a sole ownership firm may have a negative impact on its reputation. In the sample, however, it seems that the benefits outweighed the costs because many of the sole ownership firms were large (the average of net fixed capital stock of these firms was 15 million yuan).

Partnership firms cannot call themselves companies either, and most of the benefits associated with a sole ownership firm are absent. The only benefit left is that a partnership firm does not need to have standard corporate accounts, providing it certain benefits. Generally, it is envisioned that a firm with several owners will most of the time prefer to register as a limited liability company. ${ }^{2}$

However, the Law of Corporation stipulates that a manufacturing firm has to have a total of more than 500,000 yuan of initial capital in order to qualify for a limited liability company. The average original capital value of the partnership firms in the sample was 551 thousand yuan, barely above this limit. In terms of net value, the average was only 159 thousand yuan. Therefore, the existence of many partnership firms in the sample might be a 
result of the minimum capital required for a limited liability company. This is reflected by the high percentage of such firms in Beijing where firms were much smaller than in the other cities.

The limited liability company is the preferred form of ownership for larger firms not only because it provides owners with protection for their personal wealth, but also because it provides a firm with a clear internal management structure with legal backup. In a partnership, partners have unlimited liability for losses of the firm, but may not have a good idea of each other's personal wealth. So, when a loss occurs, disputes may arise as to who should be responsible for how much of the loss. In a limited liability company, a shareholder's liability stops at the amount of capital invested in the company. So the probability of a dispute is minimised.

In addition, having corporate status can enhance a firm's reputation. These benefits have prompted many firms with a single owner to find a partner to qualify as a limited liability company. Although the law does not set a minimum share for the second owner, in implementation, the share is set to be from 5 per cent to 20 per cent in the four cities covered in the first phase of survey. In some cities such as Shunde, a spouse is qualified as a partner, so a firm gets the corporate status without necessarily losing the sole owner's family's control of the firm. In other cities, such as Beijing, a spouse is not qualified as a partner. In this case, some firms just gave a nominal partner a nominal share, but both parties agreed between themselves that the share is not real. However, the agreement is not legally binding because the shares are not recorded in the legal documentation of the firm's registration. This discrepancy between personal agreement and legal protection has already brought cases in which the second owner sues the first owner to get his share out of the company. In many cases, such disputes could be devastating for the firm.

\section{Internal decision making}

Table 7.2 reports the pattern of internal management of the survey firms by ownership, firm size and length of business operation. There are two headings: one distinguishes internal management agencies by the percentage of firms using either manager meetings or Board of Directors meetings, and the other shows the percentage of important decisions made by managers, Board of Directors or others.

The results show that for the ownership forms, Board of Directors controlled most important decisions in a firm. In particular, corporations do not delegate more, but less power to managers. In particular, the Board of Directors controls all the important decisions in the three publicly listed firms. Even the 20 per cent of decisions shown to be controlled by managers, may actually be controlled 
Table 7.2 Pattern of internal management (\% of valid data)

Internal management agency

(\% of firms)

$\begin{array}{ll}\text { Manager } & \text { Board of } \\ \text { meeting } & \text { directors }\end{array}$

$\begin{array}{lcr}\text { Total } & 51.2 & 65.6 \\ \text { By ownership } & & \\ \text { Sole proprietor } & 62.5 & 50.0 \\ \text { Partnership } & 54.8 & 59.5 \\ \text { Company } & 45.7 & 81.4 \\ \text { Publicly listed } & - & 100.0\end{array}$

By size

$<51$

$51-100$

$101-500$

$>500$

By age

$<3$ years
$3-5$ years
$5-10$ years
$>10$ years

$\begin{array}{ll}62.3 & 57.4 \\ 41.9 & 71.0 \\ 51.1 & 75.6 \\ 44.4 & 77.8 \\ & \\ 51.0 & 66.0 \\ 40.5 & 67.6 \\ 49.0 & 71.4 \\ 69.2 & 50.0\end{array}$

Percentage of important decisions made by

Manager directors Others

69.0

26.9

20.1

22.3

$-$

22.5

30.4

24.4

10.1

23.5

29.1

21.2

16.4
8.0

7.7

12.4

6.7

$\begin{array}{rr}71.0 & 6.7\end{array}$

100.0

67.6

10.0

61.3

67.8

83.4

7.8

6.5

67.4

9.1

$65.1 \quad 5.8$

$70.7 \quad 8.1$
$76.0 \quad 7.6$

Source: CEO survey.

\section{Table 7.3 Certified accounting reports by ownership (\%)}

\begin{tabular}{|c|c|c|c|c|c|c|}
\hline \multirow[b]{2}{*}{ Ownership } & \multirow{2}{*}{$\begin{array}{l}\text { Firm providing } \\
\text { report }\end{array}$} & \multicolumn{5}{|c|}{ Reason for not providing the report } \\
\hline & & Not useful & $\begin{array}{l}\text { Not } \\
\text { necessar }\end{array}$ & Expensive & $\begin{array}{l}\text { Never } \\
\text { consisdered }\end{array}$ & Other \\
\hline Sole ownership & 24.2 & 17.8 & 45.5 & 3.0 & 27.7 & 5.9 \\
\hline Partnership & 43.7 & 6.5 & 51.6 & 6.5 & 27.4 & 8.1 \\
\hline Company & 47.7 & 5.2 & 41.4 & 13.8 & 25.9 & 13.8 \\
\hline Publicly listed & 33.3 & - & 100.0 & - & - & - \\
\hline
\end{tabular}

Source: Firm survey.

by owners, because the latter may well be managers themselves. Therefore, delegation in the sample firms is weak. This is consistent with the CEO interviews that found most of the CEOs were themselves owners. In terms of the decision-making process, among the 338 firms covered in the CEO survey, 110 firms have regular manager meetings, 141 firms have regular board 
meetings, and only 36 firms have both. There are several issues that are related to the internal management in the sample firms.

First, internal financial supervision is slack amongst the sample firms. Amongst 514 respondent firms, only 37 per cent provided to shareholders an annual report certified by an outside accounting agency. (Only 1.2 per cent of the firms said the accounting agency had foreign investment in it). Since the law only requests corporations to provide such a report, this low percentage may be acceptable. Further, it is not a problem for corporate governance, if a manager who fully owns the firms fails to report systematically to shareholders. However, among the 137 corporations that provided an answer, the percentage was only increased to 47 per cent (Table 7.3).

Asked why they did not provide such a report, 25 per cent of the firms without the report said they never considered it, 41 per cent of them thought it was not required, 14 per cent said it was too expensive, and 5 per cent thought the report was of no use. The report might not be of much use to a private firm for most of the time, but in case of an internal dispute, it would be difficult for the parties to resort to law for protection without one. In addition, the lack of formal accounting reports reduces a private firm's credibility when it approaches a bank or other financial intermediary to apply for a loan.

Second, as a firm becomes larger, some of the initial investors cannot keep up with the skills needed to manage the firm. The problem is acute for private firms because many of the initial owners do not have much education and training. A problem then arises as to how to place these people while bringing new people into management teams. One method created by firms is to provide early retirement with generous packages.

Third, for a private owner who wants to have further development of the firm, there is a problem of lack of advanced technical and managerial knowledge. Under these circumstances, some of them have begun to bring in outside experts onto the Board of Directors. Although the number of such firms is still very small, the trend is encouraging. The practice is more common in Wenzhou. After 20 plus years of development, many private firms in Wenzhou have found themselves no room for further development if they do not bring in people with advanced managerial knowledge and skills.

One arrangement is to bring outside experts from Shanghai and other large cities onto the Board of Directors. These new outside directors do not have shares in the firm and their roles are mainly to make strategic decisions for the firm. In the extreme case, the Board of Directors is overwhelmingly staffed with outsiders. In this case, the owners in effect surrender the firm's control to outsiders. In recent economics literature, outside directors have been found to serve in the role of arbitrators for the owners in disputes. This practice is especially common in the high-tech firms in Silicon Valley in the United States. 


\section{Box 7.1. Changing ownership and internal governance in private firms}

In Wenzhou City, private enterprises have developed quickly and dominate the local economy. Most private firms are owned by a sole owner or a family, and still managed by the owners. However, there are tendencies for ownership and internal governance to change in those firms, which have become large.

TZ is a private firm, which was established in 1990. After only nine years of growth, it became a relatively large company with over 200 million yuan of total capital and over 3000 employees. It had three experiences of internal restructuring. In 1994 it converted from a solely owned small private firm to a company. Several senior managers became owners. In 1997, it further changed into a stock-sharing company, issuing 50 per cent of its shares to over 50 middle level managers. In 1999, it bought the largest parts of the shares of over 10 member firms, and made itself the stockholding company of these firms. Thus it is able to integrate these small factories into a large one.

These changes enabled the company to recruit experienced managers from outside to improve its management, to reduce the management cost, and also to expand its size. In these two years its total capital expanded six times, and its sales expanded 4 times. Its share of the domestic market increased. Its exports increased.

Technical innovation in the company accelerated also. The company now allocates 1-2 per cent of its total revenue to research and to the development of new products.

It is interesting to find that in Wenzhou, outside directors serve a more substantial role than just being arbitrators. The owners' surrender of control to outside directors can be seen as an exchange for the latter's expertise.

Instead of bringing in outside directors, an owner can also hire competent managers to compensate for his or her own lack of managerial and other specific knowledge. This practice was common in all the cities. In this case, the owner usually gives the managers shares. This is necessary to solve the incentive problems inherent in delegation. Since the managers control the daily management and thus have a large share of the firms' control rights, it is important for owners to bring in people they can trust, usually long-time friends.

There are also exceptions. For example, a firm in Shunde wanted to list on the Hong Kong stock market by issuing $\mathrm{H}$ shares. A person who had expertise in corporate finance was required. The president of the Board of Directors met a person by coincidence whom he hired as the CEO for the firm then gave him shares. The research team found in Wenzhou an owner that delegated all management responsibilities to a manager hired from Shanghai. In Chengdu, an owner of a private firm that had been transformed from a TVE hired a young graduate with a MBA degree as his firm's top manager. The young manager helped to design an new management responsibilites system for the firm. 
Finally, a private firm has to solve the incentive problem for ordinary employees as it becomes larger and loses the intimacy of a family-like environment. Many people in China still feel uncomfortable working for a private owner. Even without this sentiment, there can still be an incentive problem, especially for employees with higher education whose contribution to the firm cannot be properly compensated by a fixed wage.

However, simply giving employees the option of buying the firm's shares cannot fully solve the incentive problem. This is because, without being listed on a stock market, the shares are not transferable. As a result, the value of shares to the employees is reduced, and for an employee who wants to leave the firm, the owner is obliged to cash out his shares. Therefore, the option of buying shares is not a perfect solution. In Shunde, the closed shareholding firms that resulted from its privatisation program are gradually concentrating ownership into the hands of a smaller group of employees, notably, the top management. This demonstrates the inability of the share option on its own to solve a private firm's internal incentive problems.

Owners of some large firms have realised that issuing shares in the open market will be necessary if their firms are to solve their internal incentive problems as well as to have further development. In fact, a major reason for a Beijing firm, the largest software firm in China, to go public was to solve its internal incentive problem. The software industry is knowledge intensive, and the incentive problem is acute.

\section{Governance and industrial organisation}

Governance issues of firms with subsidiaries are of particular interest because they can provide understanding of private firms' acquisition behaviour, as well as of how they handle the cross-firm delegation problem. Among 582 firms providing a valid entry, 19 per cent had at least one subsidiary. In particular, 28 per cent had one subsidiary, 22 per cent had 2, 27 per cent had 2 to 5 , and 24 per cent had more than 5. In addition, 27 firms or 5 per cent had subsidiaries outside mainland China.

Seventeen per cent of firms had upstream (suppliers) and 22 per cent downstream (buyer's) subsidiaries. In general, a majority of firms had industrial connections with their subsidiaries. Twenty three per cent of the firms with subsidiaries described the relationship between themselves and their subsidiaries as vertical integration, 25 per cent described the relationship as horizontal integration, and 14 per cent described it as both (Table 7.4). However, 38 per cent of the firms also said there was no specific industrial connections between themselves and their subsidiaries. The purpose of these firms plan to set up subsidiaries might be only to disperse risks. 


\section{Table 7.4 Industrial organisation (\% of firms)}

\begin{tabular}{|c|c|c|c|c|}
\hline & $\begin{array}{l}\text { Vertical } \\
\text { ntegration }\end{array}$ & $\begin{array}{l}\text { Horizontal } \\
\text { integration }\end{array}$ & Both & Neither \\
\hline Total & 22.3 & 25.0 & 14.3 & 38.4 \\
\hline \multicolumn{5}{|l|}{ By ownership } \\
\hline Sole proprietor & 28.9 & 26.3 & 18.4 & 26.3 \\
\hline Partnership & 22.7 & 27.3 & 4.5 & 45.5 \\
\hline Company & 18.0 & 24.0 & 16.0 & 42.0 \\
\hline Publicly listed & - & - & - & 100.0 \\
\hline \multicolumn{5}{|l|}{ By age of firm } \\
\hline$<3$ years & 16.0 & 32.0 & 12.0 & 40.0 \\
\hline $3-5$ years & 12.5 & 25.0 & 12.5 & 50.0 \\
\hline $5-10$ years & 21.7 & 30.4 & 21.7 & 26.1 \\
\hline$>10$ years & 33.3 & 20.0 & 20.0 & 26.7 \\
\hline \multicolumn{5}{|l|}{ By industry } \\
\hline Primary industries & 33.3 & 13.3 & 20.0 & 33.3 \\
\hline Foods and cigarettes & 38.5 & 23.1 & 15.4 & 23.1 \\
\hline Garments and other light products & 16.0 & 28.0 & 12.0 & 44.0 \\
\hline Chemicals & 22.2 & 22.2 & 16.7 & 38.9 \\
\hline Metal and nonmetal manufacturing & - & 20.0 & - & 80.0 \\
\hline Machinery & 16.7 & 41.7 & 16.7 & 25.0 \\
\hline Electronics and apparatuses & 26.3 & 21.1 & 10.5 & 42.1 \\
\hline Others & - & 40.0 & 20.0 & 40.0 \\
\hline
\end{tabular}

Source: CEO and firm surveys. Gregory et al., 2000, IFC Report., Figure 3.1, p.27 and Figure 3.2 , p.28.

Table 7.4 also shows that except for sole proprietor, other types of firms, namely partnership and company, tended to have more horizontal integration. Looking from the perspective of a firm's years of operation, it seems that the longer the firms operate, the more they tend to vertical rather than to horizontal integration. There are substantial variations across industries. For example, while food and cigarettes, and primary industries have high levels of vertical integration, machinery industry has a high level of horizontal integration.

In addition to firms with subsidiaries, 33 firms reported that they belonged to enterprise conglomerates. The average size of the conglomerates in 1998 was 1,127 employees with a sales volume of 150 million yuan and a profit of 20 million yuan. These figures indicate that the mean size of a conglomerate is that of a medium size SOE. Firms may seek to reduce transaction costs in market transactions by inviting their customers and suppliers to invest in the firm. In the sample, 24 firms had suppliers as their shareholders, 39 had customers, and 8 had financial institutions. 
To summarise, there is considerable evidence of sample firms using merger as a means to strengthen their market positions. However, the number of firms that could do so was small. In addition, the conglomerates were also small compared with SOEs.

\section{Employee involvement and labour management}

The survey data show that the role of workers is limited in the sample firms' important decision making. This is because few decisions need workers' involvement. In an SOE, there are several kinds of major benefits, such as housing, pension, health insurance, and sometimes wages that need to be distributed among all the employees fairly. In a private firm, either there are no such benefits, or if there are some, the decisions on these issues are largely made and controlled by the owner. ${ }^{3}$ The limited role of workers is also related to their weak collective bargaining power in a private firm.

In the 173 firms ( 27 per cent of the total) providing a usable entry, the average percentage of unionised workers was 60 per cent. However, the firms that did not provide an answer to the question might well have no unionised workers.

Employees in a typical private firm can be divided into two groups, one comprising local people and outside university graduates, and the other rural migrants. The first group of employees generally occupy better positions in the firms and enjoy better wages and benefits. For example, many cities require firms to purchase retirement and health insurance for urban residents, and firms are doing exactly that. Firms need the expertise of outside graduates, so they tend to treat them as locals. As the rural migrants have a high turnover rate and have accrued few skills that cannot be acquired quickly by readily available new workers, it does not make much sense from the firm's perspective to purchase retirement or health insurance for them.

As the reform of SOEs has deepened, many urban workers have lost their jobs. These unemployed workers are willing to lower their asking wages and benefits in order to find new jobs. As a result, they have become competitive in the labour market. For example, a Beijing garment company hired rural migrants in the past. These rural workers had a high turnover rate and had two strikes. The firm began to hire unemployed local workers. Because they had already lost jobs once, these local workers appreciated the work opportunity and worked hard. Apart from being more disciplined; their previous working experience reduced the cost of training for the owner.

As a result, a clear distinction has emerged in the workforce of private firms between locals (and outside graduates) and rural migrants. Members of the latter group not only have less favourable jobs and lower wages, but also are treated differently from the first in housing. Rural workers usually live in firmprovided dormitories within the factory, often 8 to 12 people in one small 
room. In contrast, local people live in their own houses. Outside college graduates enjoy much better housing provided by the firm, typically two persons in a room. The firm often buys commercial apartments for higher level employees.

Amongst the 338 firms in the CEO survey, only 20 per cent indicated that they had no labour disputes. The percentages of firms choosing the court, union in the factory, government, and direct negotiation to solve labour disputes were, respectively, 21, 41, 25 and 11 (a firm could choose more than one answer). Therefore, labour unions played a significant role in representing the interests of workers.

In addition, the roles of the court and the government were also important. It is noteworthy that a few firms consciously used labour unions and Communist Party organisations to strengthen their management. This is particularly significant in Beijing. Although conforming to the law or public relations may be one aim of setting up a Party organisation, ${ }^{4}$ it has real effects on the morale of employees. This is especially helpful for party member employees to justify their working for or even being a capitalist.

In summary, several conclusions can be made regarding the sample firms. First, internal governance of these firms is still in its primitive stage. However, to a large extent, this is consistent with their small size and ownership structure. Second, there are signs that large firms with relatively long periods of operation are beginning to adopt more open governance structures in an effort to improve performance as well as to rectify weaknesses in governance. Third, there is evidence that the sample firms are beginning to use merger as a means to reduce transaction costs in market activities. Last, while the protection of workers, especially rural workers, is insufficient, labour unions have begun to play a significant role in collective bargaining.

\section{Notes}

1. This might be due to the respondents' misunderstanding of the question so some companies were recorded as partnership firms. It could also be due to the way the sample has been selected.

2. For people who want to use unlimited liability as a sign of their credibility, partnership may be another choice. In other countries, some specific businesses, such as law firms in the United States, are required to register as unlimited liability firms.

3. There is a Regulation for Labour Management in Private Enterprises issued by Ministry of Labour on 21 September 1989, which details requirements for private firms with regard to employment contract, wage levels, insurance and welfare, safety and labour disputes.

4. The Law of Corporation requires that a corporation have both a Communist Party organization and a union. 


\section{Labour and managerial skills}

Human capital is the most important factor that constrains a firm's technological innovation and commercial success. This chapter discusses the skill profiles of managers and workers in sample firms. We then turn to the constraints that limit the sample firms' capacities to obtain and retain skilled labour. It then discusses wage differentials in size and geographic distributions. It concludes with observations on the implications of the recently introduced social security system on private firms.

\section{Skill profiles of managers and workers}

The CEO and firm surveys revealed information on the educational profiles of the sample firms' management and the background of their top managers. ${ }^{1}$ Table 8.1 shows the educational profiles of the management by firm size and city. Overall, 86 per cent of people in the management has at least junior high school education, and 59 per cent have at least senior high school education. In particular, with a percentage of 34 per cent, people with a college education are the largest educational group in the sample. In addition, there are also a small percentage of people who have masters or Phd degrees, and 0.5 per cent have foreign education. These results indicate that the educational levels of the managers in the sample firms are reasonably high.

In terms of size distribution, the educational concentration of managers in the smallest firms is at the junior high school level (34 per cent) while it jumps to the college level for the larger firms. In particular, nearly 50 per cent of the managers in firms of 100 to 500 employees have a college degree. Nevertheless, the smallest firms do not have a lower proportion of managers with a Master or Phd degree than larger firms do. They even have the largest percentage of managers with Phds (5 per cent).

Table 8.1 also puts the educational distribution into a geographic dimension. There is an overwhelming concentration, a hefty 45 per cent, of the managers in Shunde with junior high school level education. Beijing has 34 per cent at 
the same level although it also has 28 per cent of college graduates. In all the other four cities, the percentage of managers who graduated from college is above 40 per cent. Five per cent of managers each of Beijing and Chengdu have a Phd degree while there are almost none in the other cities. This contrast makes sense because those two cities have many top universities while the others have none. ${ }^{2}$ In terms of managers with foreign education, Wenzhou has 2.3 per cent, the highest percentage.

Table 8.2 reports the former working experience of managers based on the survey results from the CEO questionnaires. Overall, 75 per cent of CEOs had management experience before they had taken the current job (last column). The high percentage of amateur entrepreneurs may be taken as a sign for easy entrance into the private sector. In terms of sectoral experience in the past, 74 per cent of the CEOs were working in the industrial sector, 14 per cent in government, 5 per cent in industrial associations, 4 per cent in agriculture, 1 per cent in party organisations, and 3 per cent in other sectors.

The results indicate that besides the industrial sector itself, government is also a significant source of entrepreneurs for the private sector. In Chengdu, the research team interviewed a CEO (previously working as an official at metropolitan BICM) who set up a private firm to produce pharmaceuticals and later successfully took over a large SOE in the city. When asked whether his previous working experience in government was helpful for running a private business, he said it was very helpful without further elaboration. Presumably, advantages for ex-government officials to run private firms include familiarity with government policies and structure, good connections with government officials and departments including financial institutions, useful connections in certain industries, wider sources of information and government experience and the SOE link.

Fortythree per cent of the CEOs had had past experience of working in private firms, 33 per cent in state-owned firms ( 46 per cent in Chengdu), 13 per cent in collective firms ( 25 per cent in Shunde), and 10 per cent in others. Thus, the private sector itself and the state sector are both very important in training and fostering entrepreneurs. With further reform on SOEs, it is expected that more entrepreneurs will be seen to have emerged from the state sector. However, the largest percentage for the private sector shows that the sector itself has been becoming a source for generating human capital.

We are unable to present satisfactory statistics on ordinary employees' educational profiles because many private firms do not keep relevant records. However, education levels of ordinary workers are low because most have come from the countryside in inland provinces and most have only finished junior high or elementary school. For a firm like MD, employees with junior high or less education made up 34 per cent of its total workforce in 1998 (Box 2.2). 


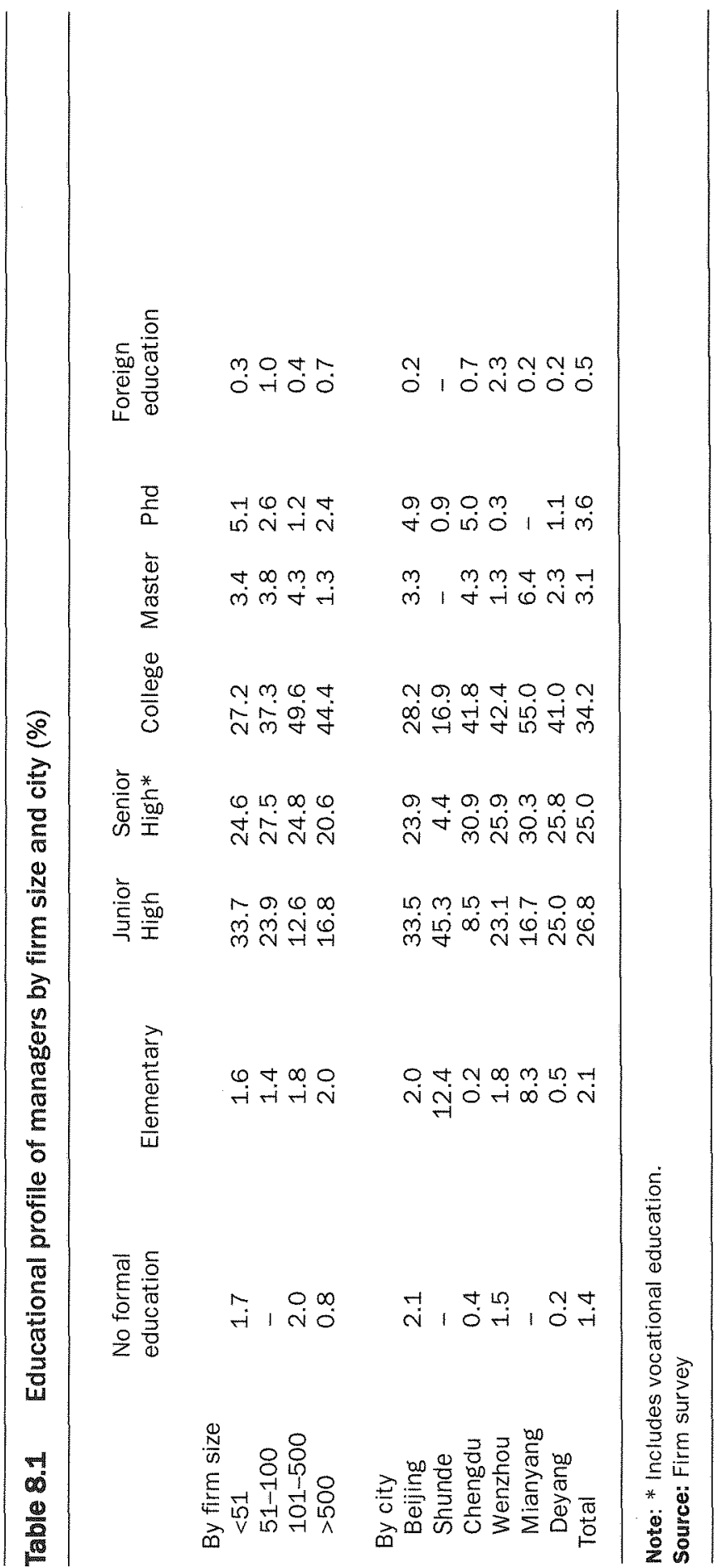




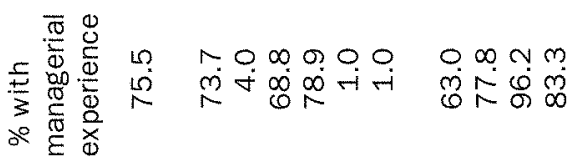
㐫

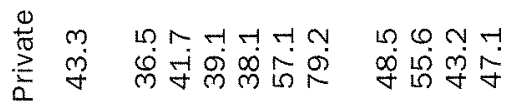

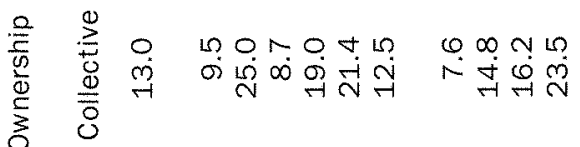
i) 10 - $M$ फ m लं लं

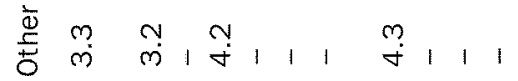

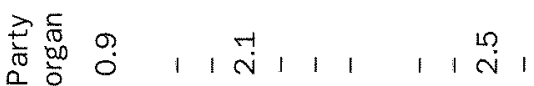

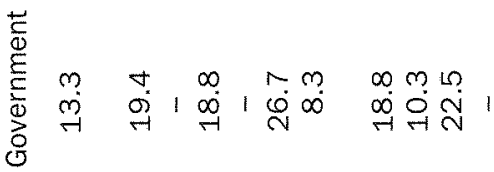
is nิ

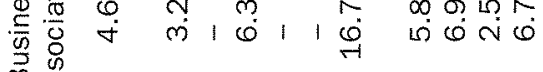
के ¿

苟 $m \quad+\infty \sim \infty m \infty \quad \infty, 0 m$

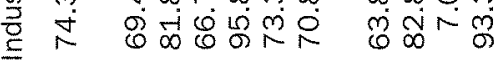
需 
This large presence of workers with minimum education is a rational choice for firms because most of their tasks require minimum skills. The real challenge is the lack of people with higher education levels and capable of technological innovations. This is pertinent to large firms that are engaged in fast technological innovations and market expansion than small and medium firms that want to have a unique product advantage. Among the 11,020 employees in MD, about 1 per cent had a master or Phd degree, 25 per cent have a college degree.

\section{Training and impediments to obtaining and retaining skilled workers}

What kinds of training are most demanded by private firms? The CEO survey revealed that technical training, accounting and marketing, and quality control are the three areas for training in most demand. Among the 338 CEOs interviewed, the percentages that identified these three kinds of training were, respectively, 59 per cent, 57 per cent, and 46 per cent. Only eight firms said that they did not need training.

Several factors impede a private firm in obtaining and retaining skilled workers. First, many college graduates do not want to work in a Chinese private firm even if it pays a higher wage than a state firm. This is more prevalent in Beijing and Chengdu where the first choices of university graduates are foreign companies, joint ventures, and government institutions.

Second, private firms generally cannot compete with the above three kinds of employers either because they have limited resources, or because they are reluctant to offer comparable wages and benefits to those employers. Private firms generally have worse working conditions and fewer benefits than the other kinds of employers. In addition, they also tend to have few college graduates, reducing the incentive for new graduates to join because of the limited opportunity to interact with people of the same background.

Private firms tend to adopt a pragmatic attitude towards human capital. While this helps them to avoid the costs of getting a wrong person, it hinders them in hiring qualified graduates. For example, $\mathrm{MD}$ only pays a masters graduate 3,000 yuan per month in the tryout period when a low level office manager can get more than 8,000 yuan per month. The tryout period is helpful for the firm to identify qualified people, but also discourages highly talented people. This is potentially a problem since the firm needs people with exceptional capacities. For example, the firm needs people for its overseas business.

With the offer of such a wage, it is almost impossible to get qualified people. The problem here is that private firms put too much emphasis on firm-specific factors and ignore the role of the economy and the educational system as a screening device for identifying talents. For example, there are many MBA programs in China now. All of them require work experience as 
well as a college diploma for entrance. Therefore, a good MBA degree itself can be taken as a sign of qualification and warrant the payment of a high salary.

Third, a high turnover rate is a factor that discourages firms to invest in training, which in turn reduces the quality of its labour force. This is more of a problem for unskilled workers. For them, a 0.5 yuan higher daily wage will draw them to a neighbouring factory. As a result, the annual turnover rate in the sample firms was between 15 per cent and 20 per cent. Such a high turnover rate makes the training of workers unattractive for private firms.

Finally, certain local policies discourage firms from obtaining qualified employees, especially college graduates. For example, most of the cities have very restrictive policies governing the granting of resident status to outside people, including college graduates of the universities in the city. Getting resident status has become very difficult for a person with only a college diploma. In Beijing, only people with a Phd degree and their dependents can get free residence status. In Shunde, resident status could be granted to people with a college diploma. Now, these people are no longer welcomed. As Box 6.1 shows, a graduate cannot get resident status and has to pay to stay. ${ }^{3}$ As solving the local unemployment problem is a high priority of local governments, setting barriers to outsiders may seem to be a rational choice on the government's side. However, the efficiency loss thus created may well outweigh the benefits.

\section{Wage differentials}

From the information provided by firms with usable entries, the average firm wage rate of the sample firms was 7,936 yuan in 1995, and 8,227 yuan in 1998 , increasing by only 4 per cent. The average real wage of the sample firms could have decreased. However, for the 132 firms providing data for both years, the average of each firm's wage growth rate was 32 per cent. The contrast seems to have been caused by the fact that firms providing usable entries for 1995 and 1998 were not all the same, with many firms established between 1995 and 1998 paying lower wages in 1998 than firms established earlier.

In both years, firms' average wage ranged from near zero to tens of thousands. Wages were higher in larger than in smaller firms, although the differences were moderate. For example, in 1998, the average wage rate for the four groups of firms had a range of from 7,548 yuan for the group with 100 to 500 employees to 9,097 yuan for the group of more than 500 employees, that is the latter was only 21 per cent higher than the former.

There were large differences among the six cities. In 1995, the average wage rates in interviewed firms in Beijing, Shunde, Chengdu, Wenzhou, Mianyang, and Deyang were 5,272 yuan, 8,560 yuan, 6,070 yuan, 12,628 yuan, 5,515 yuan, and 8,587 yuan, respectively. Wenzhou had the highest wage rate which was 2.4 times that of Beijing which was the lowest. Through 
the period of 1995 to 1998 , wage rates in Beijing, Shunde, and Chengdu increased by 43 per cent, 11 per cent, and 36 per cent, respectively, but decreased slightly in the other three cities.

The average wages for the six cities were, respectively, 7,540 yuan, 9,505 yuan, 8,266 yuan, 12,244 yuan, 4,993 yuan, and 8,497 yuan. Wenzhou still took the number one position, but Mianyang replaced Beijing as the lowest. Although the difference between the highest and the lowest remained basically steady, the wage distribution became more compact except for Mianyang, which stays far behind the average. ${ }^{4}$

The relatively small differences among firms with different sizes suggest that regional labour markets in the four cities are working efficiently. The large differences among the six cities, on the other hand, indicate that labour mobility is far from perfect in China. As in any country, we do not expect the regional wage differences to disappear in China, but the current large disparities among several relatively advanced cities show that there is plenty of room for change.

\section{The new social security system and its impact on private firms}

Starting in 1986, China has been gradually moving from a pay-as-you-go system for retirement to a more differentiated system. This movement was finally defined on 16 July, 1997 when the State Council issued the 26th document of the year Decisions on Establishing a Unified Basic Enterprise Pension System. In this document, frequently called the $26^{\text {th }}$ document, a new social security system for urban residents was defined. This new system divides oldage support into a mandatory basic system and a voluntary commercial system. In the commercial system, a worker or a firm can buy retirement insurance on a voluntary basis. Our discussion will concentrate on the basic system.

In the basic system, both the firm and the worker are required to pay for the insurance. An individual account is set up for each worker at a bank. The contribution to this account is set at 11 per cent of the worker's wage. Both the worker and his firm are required to contribute to it. The $26^{\text {th }}$ document stipulated that individual contributions could not be less than 4 per cent of the wage by the end of 1997 . This percentage would be raised by one percentage point every two years until the individual contributions reached 8 per cent. In the course of the transition, the firm would fill in the gap between individual contributions, and 8 per cent.

In addition to the individual account, there is a public account contributed solely by the firm. The $26^{\text {th }}$ document stipulates that the total firm contribution (including its contribution to the individual account) normally should not exceed 20 per cent of the total payroll. Funds in the individual account belong to the worker and are to be inherited. Funds in the public account are pooled together. Assuming a life expectancy of 70 years of age, a wage growth rate 
equal to the interest rate, and a contribution of 35 years, the two accounts added together will provide a replacement rate of 59 per cent of the prevailing wage rate at the worker's retirement. A more efficient investment system, generating high rates of return, would raise this ratio.

The transition from the old system to the new system has commenced. However, implementation is not even across the country. For example, Beijing requires a firm's contribution of 19 per cent and an individual's contribution of 5 per cent. In Shunde, firm contribution is set at 13 per cent, and individual's contribution is the same as in Beijing. The coverage in Shunde is 80 per cent for local people, 30 per cent for migrants. Since the $26^{\text {th }}$ document only governs people with an urban residency, the 30 per cent might have captured a fairly large portion of the urban migrants in Shunde because like any other place, most of the migrants come from the countryside. However, the local social security bureau still complains that the coverage is low because there is a deficit of more than 20 million yuan each year.

Discussion is underway to include rural migrants into the current pension system. Shunde is attempting to do this. Beijing is implementing this policy. In addition, a major reform in healthcare has been announced. This will also be a three-pillar system of health care. In Shunde, a preliminary system has been established with contributions divided into one third for each of government, enterprise, and individual. Currently, the total premium for a worker is 47.5 yuan/month, and 400 thousand people (about one third of the local population) have joined the system. The system only pays a worker when he has to stay in the hospital to get treatment, but running at a deficit.

The two new systems have received strong resistance from private firms, especially when they are required to cover rural migrants. There are internal inconsistencies for rural migrants entering into the pension system. Because this group of people has a high mobility rate, a major problem arises when they leave a job about whether to cash their and their firms' contribution or to transfer the contributions to their own provinces. Both options have problems. In the first option, the firm incurs large losses. In the second option, the migrant incurs a loss because he or she is not going to get the benefit after returning to the countryside in the home province because of the major costs involved in claiming the money in the future.

There are also problems of how to balance the interests of different provinces. To private firms, the immediate consequence is that their operational costs will increase considerably. In most cases, pension contributions and health insurance are used by them to reward loyalty. As a result, only local people and migrants whose qualifications are in demand have these benefits.

In the Survey, cases of pension and healthcare are scant. Among the 628 sample firms, only 90 firms provided a figure for the amount of pension in 
1998 , and their average of pensions as a percentage of the total payroll was only 7 per cent. In addition, 102 firms provided information for their healthcare expenditures, and the corresponding average percentage was 8 per cent. As for regional differences, Chengdu and Beijing had the highest percentages of about 10 per cent for both pension and healthcare. But in terms of coverage measured by the percentage of firms providing usable entries, they were the lowest. For example, the pension coverage was 16 per cent and 8 per cent, respectively, whereas in other cities it was above 20 per cent. The highest was Wenzhou (31 per cent).

The research team found only a few cases in Beijing in which benefits were extended to all the migrants. However, the benefits are not specific to an individual. A firm purchases the benefits for a fixed number of employees. When an employee leaves the firm, the newly hired employee takes the slot. By doing so, the firm fulfils the government requirement and saves its money. In Shunde, almost no rural migrants obtain the benefits. However, each firm buys mandatory accident insurance for all of its workers. The insurance itself exempts the firm from liability in work accidents, which sometimes can be highly expensive to settle.

To a large extent, Beijing and Shunde's early extension of the coverage of both the pension and healthcare systems to rural migrants was prompted either by the pressure to remedy the deficit, or by their desire to limit the number of migrants in the cities. While the first factor is understandable, yet not justifiable, the second factor may have been misguided. A comprehensive study shows substitution effects of migrants workers for local's jobs are low (Li, 1997). In light of this, the policy to limit the presence of rural migrants cannot be justified. Rural people have land as the last resort. The current egalitarian land distribution serves as an in-kind social security system for the rural population (Yao, 1999). The rural population will still rely on this system for a long period of time basic old age support as well as current income insurance against adverse shocks.

In summary, the sample firms have strong profiles in terms of educational levels and past managerial experiences. The impediments to their obtaining and retaining well trained workers are related to their cautious approach to compensation of new employees, high turnover rates, the reluctance of people to work in private firms, and local government protection of local employment. The study of the wage differentials showed that local labour markets are quite efficient, but a more unified national labour market is yet to come. Finally, the speeding up of the implementation of the new pension and healthcare systems has met strong resistance from the sample firms. In light of its internal inconsistency, the resistance shown by firms, and the fact that the rural population has some insurance through the egalitarian land tenure system means, the extension of the coverage to rural migrants will not come soon. 


\section{Notes}

1. Due to different understanding of what 'management' meant to the respondents, the management could include only the top managers or these managers plus medium-level managers.

2. Cities like Beijing and Chengdu have also set up high-tech development areas or zones with special policy packages in place to attract Chinese students or scholars overseas to work there.

3. In some small size towns, people paid around 6,000 yuan to have a permit to live in cities a few years ago. But for large cities like Beijing, there is no such policy due to the tight control over the inflow of population.

4. Of course, there are differences in living costs across regions. For example general price levels in Chengdu and the other two cities in Sichuan Province are lower than that in the coastal cities such as Beijing and Wenzhou. These differences in living costs should be considered when comparisons are made across regions in wages. 


\section{Technological challenges}

Firms that occupy a unique technological niche were the most successful amongst the sample firms. Even in the current economic slowdown, they do not feel much market pressure (see Box 9.1 for a description of MD in Shunde). This chapter describes the sample firms' pattern of technological innovations, analyzes problems in $R \& D$ and acquisition of technologies, and highlights the importance of the protection of intellectual property rights in fostering private firms' innovations.

\section{The pattern of technological innovations}

Amongst the 323 firms providing usable answers, 93.5 per cent regarded new technologies and new products as very important for their development. There were only 21 firms ( 6 per cent of the 338 firms given the CEO survey) that clearly indicated that new technologies and new products were not important for them. In contrast to the large proportion of firms that regarded new technologies and new products as important, the frequency of new products was relatively low amongst the sample firms. In the last five years, 16 per cent of them had not introduced any new products in the year preceeding the interview, 51 per cent had 1 to 5 new products, 18 per cent had 6 to 10 , and 15 per cent had more than 10 . Therefore, on average, two-thirds had less than 6 new products a year.

Regional and size differences were prominent (Table 9.1). Wenzhou had the highest rate of product innovation, with 19 per cent of its firms having introduced more than 10 new products in the last five years, and 33 per cent 6 to 10 new products. Several other cities had about the same percentage for firms having introduced more than 10 new products, but the incidence of firms having 6 to 10 new products was much lower than in Wenzhou. One reason why Wenzhou had more new products might be that its industries were concentrated in small electronic parts, garments, and small consumer goods such as buttons where competition was more intensive, and where there were greater opportunities for less elaborate product differentiation. 
Beijing fared worst again. This could be related to the overwhelming presence of small firms. This conclusion is evident in the difference in firm size. For the group of firms with less than 50 employees and the firm with 51 to 100 employees, the percentages of firms with no more than 5 new products in the last 5 years was 68 per cent and 79 per cent, respectively. For the two groups of larger firms, the percentages dropped to 56 per cent and 50 per cent, respectively. In particular, 33 per cent of the firms with more than 500 employees

\section{Box 9.1 MD: Development by way of innovations}

MD, located in Beijiao township of Shunde, is a company specialising in making home appliances such as electric fans, air-conditioners, water heaters, rice cookers, etc. It had 11,020 employees, and a sales volume of 5 billion yuan in 1998. It is the world's largest supplier of electric fans and China's second largest supplier of airconditioners. In terms of sales volume, it was the $193^{\text {rd }}$ largest firm in China. The company was started by its current president and CEO, and 22 others in 1968 as a small cooperative factory making simple farm tools. In the early 1980s, it started making electric fans, mainly by imitating the then famous domestic brands such as Huasheng. At the end of the 1980 s and early 1990 s, its products were expanded to other small home appliances.

In May 1992, MD undertook a major institutional innovation by taking the lead in privatisation in Guangdong province. After privatisation, the company was first listed on the Hong Kong stock market as an ' $\mathrm{H}$ ' share. It soon broke the entry barrier and was listed on the Shenzhen stock market as an A share in November 1993. Privatisation and the subsequent listing on the open market have helped MD to make a leap in its development. In 1992, its sales volume was only 380 million yuan; in 6 years, that figure reached 5 billion yuan in 1998. With the funds raised in the stock market and reinvestment of profits, it began to enter the air-conditioner market and soon became one of the biggest air-conditioner producers in China.

The motto of MD president is: 'It is better to give up a 1 million order than to give up a person whose expertise is useful to the company.' MD has a strong mix of human capital. Among the 11,020 employees, 110 have a masters or Phd degree, 2795 have a college degree, and 4352 have a high school or professional diploma. The high concentration of human capital enables MD to lead the market by way of rapid technological innovation. It has more than 200 patents and 15 products that are designated as national or provincial new products. In addition, more than 400 of its products have obtained quality certificates in China and several other countries. Its products are being sold in every continent. In addition, it has led the trend in innovative internal management. It is the first company in China that started MRP II, a firm management system that provides a total solution to a firm's daily planning and management.

The aim of MD is to reach a sales volume of 9 billion yuan by 2000 . Judging by its growth record and admirable perspective, this aim will be realised. 


\section{Table 9.1}

The distribution of new products by city and firm size (\% of firms with number of new products)

\begin{tabular}{lrrrr}
\hline & None & $1-5$ & $6-10$ & $>10$ \\
By city & & & & \\
Beijing & 24.5 & 49.1 & 18.9 & 7.5 \\
Shunde & 31.3 & 43.8 & 12.5 & 12.5 \\
Chengdu & 17.4 & 45.7 & 19.6 & 17.4 \\
Wenzhou & 9.5 & 38.1 & 33.3 & 19.0 \\
Mianyang & 11.1 & 55.6 & 16.7 & 16.7 \\
Deyang & - & 73.5 & 11.8 & 14.7 \\
By firm size & & & & \\
$<51$ & 22.4 & 46.3 & 16.4 & 14.9 \\
$51-100$ & 15.2 & 63.6 & 12.1 & 9.1 \\
$101-500$ & 2.2 & 54.3 & 28.3 & 15.2 \\
$>500$ & 11.1 & 38.9 & 16.7 & 33.3 \\
\hline
\end{tabular}

Source: Firm survey.

had more than 10 new products whilst 22 per cent of the firms with no more than 50 employees had no new products. This size-related distribution of product innovation is also revealed in the number of patents applied or bought by the sample firms.

Amongst the 299 firms with usable entries, 38 per cent of them applied for or bought patents. Larger firms had done more of this than smaller firms had. For the four groups of firms, from the smallest to the largest, the percentages of firms that applied for, or bought, patents were respectively 29 per cent, 42 per cent, 50 per cent, and 59 per cent. In terms of regional differences, Beijing still fell behind the other cities with only 24 per cent of such firms. Deyang had the highest percentage at 60 per cent. Other cities were concentrated between 35 per cent and 45 per cent.

Amongst the 276 firms with a usable entry, 50 per cent had experience of using foreign technologies. Regional variations were small, with the lowest being 45 per cent (Beijing) and the highest 56 per cent (Chengdu). However, size variations were large. The percentages of the two groups of smallest firms were 40 per cent and 39 per cent, respectively, while those of the two groups of largest firms were 67 per cent and 71 per cent, respectively.

The CEO questionnaire also asked whether cooperation with universities and government research institutes was important to a firm. While 79 per cent of the firms regarded cooperation as important, it turned out that the cities with more affirmative answers were not Beijing or Chengdu where university 
and government resources are most abundant, but small cities such as Mianyang and Deyang where affirmative responses reached 92 and 96 per cent respectively. Larger firms generally gave more positive answers than smaller firms, although the differences were not strong.

The size-related differences are consistent with the findings of other studies. For example, a study conducted by a group of researchers at Tsinghua University on 1,051 firms in the period 1991 to 1993 found that R\&D expenditures of large, medium, and small firms were 0.8 per cent, 0.3 per cent and 0.4 per cent of total sales, respectively. The national average for the manufacturing sector was 0.5 per cent in the same period. A study by the Ministry of Sciences and Technologies in Yichang, Hubei Province in 1990 revealed a similar pattern, with the ratios for the three groups of firms being 2.1 per cent, 1.3 per cent, and 1.2 per cent, respectively. ${ }^{1}$ In fact, the two quoted studies also revealed striking regional differences. In the next section, an analysis is provided of the underlying factors that have driven the size and regional differences in firms' reporting of technological innovations.

\section{Factors affecting firms' technical capacities}

Many studies have identified a lack of human capital, finance and information, and technological piracy, as the most important factors that impede a firm's technical capacities in China (see Wang and Yao, 1998 for a synthesis of the studies). While this is also the conclusion of the current study, we have found different intensities of these factors and some specificity for private firms.

An obvious impediment to the sample firms' technical capacities is the lack of human capital. In this regard, large firms are in no better position than small firms, but the problems they face are different. Large firms need are R\&D specialists and well-trained workers to carry out sophisticated tasks. Yet, because of the impediments laid out in Chapter 8, for example 'university graduates' preference for other employers, private firms' under-utilisation of market establishments, high worker turnover rate, and local government policies, it is hard for a private firm to obtain and retain qualified employees.

Small firms need is not for not specialists, but for general engineers who, possibly with limited education, can identify and transplant existing technologies as well as conduct simple technical improvements. This is not because small firms do not want to engage in technological innovations. But taking other constraints into consideration, the adoption of established technologies is usually an optimal choice for them. However, there is a price for doing so. If a firm can learn one technology, other firms can do the same in the current environment of weak enforcement of intellectual property rights. This is one reason why most of the private firms in one locality produce the same product and enter into head-on competition with each other. 
Without further technological progress, increasing competition will drive down the profit margin to the point where many firms will not survive. One strong opinion expressed by small entrepreneurs was that market competition was so intense that they were fighting for salaries instead of for profit. While intense competition is related to overall macroeconomic conditions in the country (Chapter 2), it is also a result of the lack of technological progress among small firms.

For large firms pumping out hundreds of new products a year and smaller firms with a unique technical niche, complaints about market competition were heard less frequently. This suggests that the best way for a small firm to get out of the trap of intense competition is to develop new products that others cannot easily imitate. The probability of this is severely limited by the lack of qualified personnel. If it is difficult for large private firms to recruit and to retain qualified personnel. It will be even more difficult for small private firms to do so.

The second impediment to a private firm's improvement of its technical capacities is its lack of adequate financial resources. As pointed out in Chapter 5 , most private firms are operating under a tight liquidity constraint. Priority in use of limited financial resources has to be given to matters essential for shortterm survival. Technical innovations are low on their priorities.

In addition, government lending and taxation policies, besides the effects discussed in previous chapters, also have specific adverse effects on private firms' technical investments. The central bank limited the number of loans with more than one-year terms that commercial banks can issue. State firms can circumvent this restriction by getting special loans reserved for technical innovations. But private firms do not have this privilege. Consequently, it becomes difficult for private firms to engage in an $R \& D$ project that takes more than one year to complete.

Furthermore, the current tax code does not allow firms to deduct capital investment from of the base of the VAT. Since VAT is the largest tax for firms, this restriction severely dampens a firm's incentive to make new investments. Repressive government policies and underdeveloped institutions in the financial arena discussed in Chapter 5 also have profound implications on a private firm's ability to engage in R\&D activities. In particular, the lack of financial intermediaries, stock markets, investment banks, and venture capital to provide long-term capital is important. In this context, large firms have a strong advantage over small firms because the banks are willing to provide them with continuous unsecured credit.

The third impediment is the lack of access to useful information. The CEO survey revealed that 36 per cent of the firms regarded the lack of technical information as a major hindrance to their operation, and 21 per cent regarded the lack of training information as a major hindrance. Here we turn to discussing the last factor on our list, technological piracy. 


\section{The protection of intellectual property rights}

The legal protection of intellectual property rights offers a firm monopolistic gain associated with its innovations. Technological piracy supresses technological innovation. Law enforcement is weak in China, exposing firms to rampant piracy. How do firms cope with the situation?

The first type of response is to speed up technological innovation. This shortens the product life cycle and leaves the imitators no time to catch up. It requires considerable human capital and financial resources to do this. Here, piracy actually speeds up technological innovation.

The second type of response is more passive. A firm does not apply for a patent to keep its new product secret. The firm assumes that the new product will occupy a fair share of the market before being pirated. If a firm patents its new product before production, it is likely that pirated products will be produced at the same time. This type of response is a direct result of weak law enforcement.

The third type of response is to self-policing of products. Firms commonly use their sales network for this task. Usually it works as local governments generally take a cooperative position. However, when a firm cannot get assitance from the government, it may resort to unlawful action such as sending people to destroy the pirate's factory (Chapter 4).

The fourth type of response is to use collective power to enforce the protection of technological innovations. In Chapter 10, the case of a button industry chamber of business in Wenzhou is discussed. The chamber of commerce, with support from the township government, provides protection for button products to members in return for fees. It has been working effectively although its extension of the enforcement to nonmembers raises legal concerns.

The final type of response is to avoid products that are easily imitated. This is common in high-tech industry. Products that easily become victims of piracy have low entry barriers. In this regard, software, especially that from a large body of end users is the most vulnerable. For this reason the software industry is still primitive in China. The best Chinese word processing software belongs to Microsoft. Large companies have financial, legal, and social resources to fight piracy through the legal system whereas small companies do not.

Domestic IT companies concentrate on specific niches where piracy is less of a problem. Examples occur in IT products that demand intensive human capital inputs. For example, the largest software company in China specialises in enterprise management information systems. Since systems are complicated, simple technical protection prevents piracy.

Generally, firms are reluctant to resort to lawsuits to stop piracy. In addition to weak law enforcement, firms also have other considerations. One is that the violators are everywhere, and taking them all to court is impossible. In the case 


\section{Box 9.2 Intellectual property rights and technical innovation}

HDL, a building material producer in Wenzhou City, was established in 1993 by 17 private investors (but 15 of them have since quit). Now it has a total capital of 20 million yuan with 7 million in bank loans. Due to the sharp competition, the profit margin is low. But the general manager believes that the company is doing well. He said small firms, private firms in particular, face two major problems.

One is the risk in research and development. The current legal system does not provide much protection to firms' patents and brands. To develop a new product, a firm only has an 8-10 per cent chance of success. Once it is successful, it will be soon be copied by other companies. Two new products developed by his company were copied by others with minor changes. With one of them, the copying company was sued in court, spending one and a half years and 200 thousand yuan in the legal process. But the final judgment allowed both companies, the inventor and the company that copied, to produce the same product. A technician of the company was also 'hunted up' by another company, together with the know-how of his company. The manager concluded that, "you were waiting to die if you don't develop new products, and you were seeking to die if you do: you spent money for others.'

of local competition, violators may reside just next door. Taking the case to the court will be regarded as with distaste by both sides. However, a large percentage of firms having applied for or bought patents show that they still have some confidence in the law. Even if they do not have 100 per cent confidence, the legal system is still their last resort.

Four main conclusions have emerged in this chapter. First, the distribution of new products is clearly linked to firm size, and large firms consistently surpass small firms in several aspects of technological innovation. Second, geographical differences in performance on innovation are linked to variation in typical firm size across localities. Third, the better performance of large firms is caused significantly by their advantageous positions in human capital and financial resources. Fourth, firms have developed several expedients to combat technological piracy in an environment of weak law enforcement, with varying effect.

\section{Note}

1. The two studies are cited from Wang and Yao (1998) 


\section{0}

\section{Laws and government administrative regulations}

The role of law and regulation in the development of the private sector has emerged in a number of earlier chapters. This chapter provides a synthesis and highlights critical issues of legal reform. It also discusses the role of instituions for dissemination of business information.

\section{Laws and regulations related to private firms and their impact}

In China, regulations issued by the State Council and laws passed by the National People's Congress (the legislator) effectively have the same power although the latter has a higher hierarchic place than the former. Currently, there is one law and one regulation governing the registration and operation of a private firm, that is the Law of Incorporation, and the regulation, Tentative Stipulations on the Registration of Individual and Private Enterprises (TSRIPE). The TSRIPE was issued in 1988. Although it is called tentative stipulations, it has been in effect for more than ten years. It governs the registration of getihu and private firms of sole ownership and partnership. The Law of Incorporation governs the registration and operation of limited liability companies.

A new law governing the registration and operation of partnership firms, the Law of Partnership Firms, is in the process of obtaining approval from People's Congress. Another law governing the registration and operation of private firms with sole ownership is the Law of Private Sole Ownership Firms which became effective in 2000. In addition, a law aimed at protecting small and medium-size firms, the Law of Protections on Small and Medium-size Firms, is also under discussion and will have effects on private firms because many of them are small and medium-size firms.

In addition to the major laws and regulations, there are smaller regulations issued by the State Council which affected private firms during specific periods. Some local governments also issue local regulations that are related to private firms. For example, the Guangdong government in 1998 passed a resolution through the local legislature, Stipulations on the Protection of Private Firms. 
Other general laws and regulations also affect the operation of private firms. For example, the current tax collection procedure has a stronger effect on private firms than on SOEs (Chapter 6). Since many of the issues have been discussed in the previous chapters, we concentrate in what follows on the impact of the TSRIPE, and the Law of Incorporation and Law of Private Sole Ownership. The several issues related to the four laws and regulations, are discussed in turn.

First, firm registration is a process of application that requires the approval of the BICM. Normally, there are requirements for minimum registered capital for a company (manufacturing and wholesale sectors: 500,000 yuan; retail: 300,000 yuan). In industrial countries, firm registration is only a filing process and no restrictions are placed on minimum capital. The requirements of application and minimum registered capital constitute a major source of rentseeking behaviour by government agencies or officials.

For example, a local BICM branch usually has a consulting office that provides advice to firms and even takes their cases and runs through the registration process for them. Of course, firms need to pay for the services. If such an office is forbidden, the privilege of opening a consulting firm will be granted to people that have special links with the branch. In addition, the entry barriers could also exclude potentially good firms from entering the market. Last, the process of approval can take a long period of time and many people are exhausted even before their firms are open for business.

Second, the Law of Incorporation does not allow a single individual to register his firm as a limited liability company. As discussed in Chapter 7, a company has several important advantages over other kinds of firms. In addition to the protection of personal wealth, being a company also has a positive effect on the firm's reputation. Because information asymmetry is a big issue in the market, even having the word 'company' in its name will help a firm's establishment in the market.

The exclusion of firms with a single owner from registration as companies has a strong effect on limiting development of private firms. Limited liability offers strong protection to entrepreneurs when their firm fails. It is the insurance for an entrepreneur's risk-taking activities. Without this insurance, entrepreneurs' personal wealth is at stake, so their desire to undertake risky but potentially profitable activities is lowered. This is more important when the firm becomes large and the stakes become very high. Therefore, it was observed in the Survey that almost all the larger firms registered as companies even when they had only one effective owner. They circumvent the restriction by inviting a friend to be a nominal owner. As discussed in Chapter 7 , in some cases this arrangement created legal problems for the firm when the friendship ended.

On the other hand, the exclusion of a single individual's registration of a firm as a limited liability company also has a rationale under weak government 
regulatory capacities. When government regulatory capacities are weak, granting a single owner company status may increase the incidents of cheating in the economy because of the moral hazard problem. It is often observed in industrial countries that bankruptcy is used as a way to evade debt repayment although at the cost of not being able to participate in other companies. With two or more people in the company, however, a balancing mechanism can be planted in the firm so cheating by one shareholder becomes a bit more difficult.

Third, there is still a division between getihu and private firms, and the dividing line is still whether the employer hires more than 8 people. The Law of Private Sole Ownership Firms is likely to inherit this division although there have been constant calls to eliminate it and treat a getibu the same as a private firm. One major impediment to the elimination of the division is related to the income of local BICMs. Local BICMs collected management fees on both private firms and getihu in the past. Recently, private firms have been exempted from the fee, but getihu have continued to pay it. If getihu were treated the same as private firms, the fees collected on them would be eliminated.

The truth is that the management fee collected on getihu constitutes a large portion of local BICMs' budgets. For example, in Beijing, a getihu needs to pay a management fee equivalent to 5 per cent of its sales. The total income contributed by the fee constitutes half of Beijing BICM's budget. Therefore, the operation of local BICMs would be paralysed if they were not allowed to collect the management fees and there were no new budget allocations or authorisation of new revenue sources from the government.

If the division between a private firm and a getihu is retained, the TSRIPE has to remain in place to govern the registration of getihu, and China's laws for business operation will remain incomplete. In addition, the existence of the management fee creates ample room for rent-seeking behaviour because the amount of fee a getihu pays, to a large extent, depends on his personal relationship with the BICM official in charge. Last, getihu was created under a special background that averted private ownership. Since this background no longer exists, the justification for its existence is not warranted. Therefore, it is meaningless to retain the division between a private firm and a getihu. The central and local governments should provide new budgets to local BICMs so they do not need to rely on the management fees.

Last, the new Law of Partnership Firms does not provide a firm with the flexibility of having a mixture of unlimited liability and limited liability capital. This flexibility allows one or more parties of the firm to shoulder unlimited liability and other parties to shoulder only limited liability. The former parties are usually insiders of the firm, and the latter parties may be outside investors. This kind of arrangement is very helpful for high-risk industries such as the 
high-tech business. The original owners may have a potentially high-yielding but also risky project, but lack the financial capacities to undertake it.

By taking unlimited liability, the owners can show outside investors that the project and the firm are really promising. To protect the outside investors, offering them limited liability is a good choice. However, the flexibility may lead to problems for the SOEs in China. For example, an individual may buy an SOE's shares with limited liabilities, and the state takes unlimited liability. Under this arrangement, the individual, if enough shares have been purchased to control the firm, may be in a position to transfer the firm's assets out of the firm, and the state ends up shouldering all the losses. This scenario is real because there is no one with the financial incentive to guard the state assets.

Related to firm registration, there is a problem with the current taxation system. Getihu income is only taxed once. But for sole ownership and partnership firms, the owner is taxed twice, once on personal income, and once on the firm's profit. However, a private firm owner is no different from a getibu in any economic sense, and therefore it does not make any sense to treat them differently for taxation purposes. Since all three kinds of entities bear unlimited liability, they should be treated equally in terms of tax burdens.

\section{Regional differences in law enforcement and administrative performance}

The research team found that law enforcement and administrative performance differ amongst regions. Generally, Shunde fares better than the other cities in all aspects. For example, the CEO questionnaire asked how many major laws, regulations, or policy changes happened in the last three years that affected a firm's business. In Shunde, the average answer was 0.36 times while the average for all the six cities was 2.5 times. In particular, Beijing had 6.2 times. Therefore, the policy environment is much more stable in Shunde than in other cities.

In addition, more people in Shunde than in the other cities trusted the courts when they had a dispute. Forty-one per cent of the firms in Shunde went to the courts in a dispute while the average for all the cities was 31 per cent. Although Mianyang had a slightly higher percentage of 43 per cent, it also had more firms relying on family and friends (11 per cent) and on government agencies (14 per cent). In contrast, firms in Shunde seldom relied on means other than the courts. In terms of administrative irregularities, Shunde is also the best. In Chapter 6 when taxation was discussed, it was shown that Shunde was the fairest and the most predictable in terms of tax and fee burdens although its taxes and fees were not the lowest.

In Beijing, frequent government policy changes were the subject of heavy complaints from private firms. In particular, the government's sudden compulsory acquisition of land was a particularly annoying factor to many 
private firms, and in the extreme case, a promising firm could be destroyed (Box 10.1 gives an example). Recently, the Bureau of Public Health issued a directive to close all the restaurants that had a floor area of less than $30 \mathrm{~m}^{2}$ because it thought that small restaurants did not meet hygiene standards. This directive, if strictly enforced, would result in the closure of more than 3,000 small restaurants. The Bureau of Publications followed with a directive to close all the bookstores that had a floor area of less than $50 \mathrm{~m}^{2}$. If this directive is implemented, most of the small bookstores in Beijing will be closed.

Shunde's better performance in terms of predictability and regularity comes from its unique government reform carried out as early as 1993. The major theme of the reform was downsizing and transformation of the role of the government. The number of departments in the government was reduced from 49 to 29, and the number of employees from 1,400 to less than 900 . This reform was implemented six years earlier than similar reforms in other parts of China. Reforms elsewhere only began in 1999, and were far less radical. ${ }^{1}$

Accompanying the downsizing and consolidation of functional departments, the role of the government has been radically transformed from a player in the economy to the arbitrator and service provider of the economy. Together with the massive privatisation program, the radical government reform has created new institutional and social capital that is compatible with a private ownershipbased market economy. Now, fairness, openness and integrity are the banner of the administrative management in Shunde. Although corruption has not

\section{Box 10.1 Firm P's loss of its land}

Firm $\mathrm{P}$, located in the western suburbs of Beijing was a repair shop specialising in Volkswagen products. It was a new firm established in 1998 with 450,000 yuan registered capital and 15 employees. It signed a contract with the township's government for the use of the latter's land for ten years because the latter assured it that there would be no land acquisition for at least four years. The contract was to be renewed on a yearly basis. After the contract was signed, the owner of the firm built the shop on the designated land and began operation. However, in only half a year, the municipal government notified the firm that its land was to be used for a new road and it had ten days to find a new place for the shop. This short notice killed the shop because there was no way for it to find a new place in just ten days and its hard-won customers would be lost in the time period when it tried to find a new place. In addition, no compensation was promised by the government although the owner checked the Land Law and Law of Land Requisition and found that it should be compensated. The owner tried to contact several government agencies, but none of them would take on the case. Moreover, the ten-year contract with the township government had to be brought to an end. Again, there was no compensation for anything. A promising firm died. 
been eliminated in Shunde, the predictability and regularity brought by the government reform has provided the economy a stable business environment.

In terms of government services, the results are more diverse. Table 10.1 shows some statistics on the power supply in the six cities based on the questions directed to the price of electricity and the power cuts in the last five years. Although Shunde had high electricity prices, it also had the lowest number of power cuts and lowest average loss. Wenzhou had the highest number of power cuts, so it is not surprising to find that it had the highest percentage of firms that had their own generators. Shunde was also the fastest city in installing telephones, taking only 6.3 days on average. Wenzhou was only slightly slower at 6.4 days. Beijing, where it took 22.5 days to install a telephone, was the slowest city.

In terms of the installation fee for a telephone, Mianyang was the highest, 3,709 yuan; Beijing was second, 2,645 yuan. The lowest was Deyang, 1,184 yuan. None of the firms in Shunde complained about the quality of the phone services, Wenzhou again took the second place, with only 5 per cent of its firms making complaints. In Beijing, the percentage was also low (8 per cent). The three cities in Sichuan province were the worst, with the percentages of firms making a complaint in Chengdu, Mianyang and Deyang, 22, 31, and 23 per cent respectively.

For roads, Beijing and Chengdu had the lowest satisfactory rate of 75 per cent, with the highest Mianyang at 96 per cent. Shunde had the most expensive road system in terms of taxes and tolls. In 1998, a truck on average paid 16,083 yuan for taxes and toll. Beijing had the cheapest road system. In 1998, a truck's taxes and tolls expenses were 8,526 yuan. For the other cities, Chengdu was 9,885 yuan, Wenzhou 10,350 yuan, Mianyang 12,787 yuan, and Deyang 13,895 yuan. Therefore, it seems that there is an inverse relationship between city size and transportation costs. Large cities like Beijing and Chengdu have a higher concentration of industries and also provide more free roads. In contrast,

Table 10.1 Power supply by city

\begin{tabular}{lccrlc} 
City & $\begin{array}{c}\text { Elec. price } \\
\text { (yuan/kwhr) }\end{array}$ & $\begin{array}{c}\text { Power cuts } \\
\text { per year }\end{array}$ & $\begin{array}{c}\text { Ave. length } \\
\text { (hrs) }\end{array}$ & $\begin{array}{l}\text { Ave. loss } \\
\text { (yuan) }\end{array}$ & $\begin{array}{l}\text { Firms with } \\
\text { generator (\%) }\end{array}$ \\
Beijing & 0.91 & 8.4 & 4.6 & 17,754 & 1.6 \\
Shunde & 1.02 & 7.4 & 7.7 & 15,000 & 42.9 \\
Chengdu & 0.76 & 9.6 & 13.4 & 38,743 & 40.0 \\
Wenzhou & 1.08 & 24.1 & 9.9 & 28,911 & 87.2 \\
Mianyang & 0.72 & 12.0 & 7.6 & 44,022 & 36.4 \\
Deyang & 0.59 & 14.7 & 5.0 & 16,446 & 38.6 \\
Total & 0.84 & 12.4 & 7.8 & 36,886 & 37.4 \\
\hline
\end{tabular}

Source: From the survey results. 
smaller cities do not have high industrial concentration so firms' transportation costs outside the city and on toll roads and highways are increased.

In the area of water supply, Wenzhou was the worst. On average, firms experienced 27 water cuts in a year. Chengdu was the best, with only three. Shunde and Deyang experienced 9 and 5 cuts, respectively. In terms of the influence on production, 68 per cent of the firms in Wenzhou said water cuts had negative effects on production and Mianyang 62 per cent. Other cities had much lower percentages (in the thirties).

For the drainage system, Wenzhou was perceived as being the worst. Only 65 per cent of firms in Wenzhou said that the drainage system worked properly while the approval rates in other cities were much higher. In particular, the rate reached 100 per cent in Mianyang.

\section{Business intermediaries and government services as a bridge for information dissemination}

The CEO questionnaire asked whether it was difficult for a private firm to get various kinds of information. In terms of business infrastructure, four types of information were regarded by a significant number of firms as highly difficult to obtain. There was information about financial sources (46 per cent, 230) ${ }^{2}$, information on investment opportunities ( 43 per cent, 223), information on markets (32 per cent, 265), and information on technologies (36 per cent, 233). The perception of government services was better, but far from favourable. Only 20 per cent (263) said it was difficult to get information on licensing and general government regulations. The percentages of firms saying it was difficult to get information on tax and accounting, foreign trade, and other policies were, respectively, 21 per cent (262), 28 per cent (201), and 23 per cent (189).

The high level of difficulty related to obtaining information acquisition shows that business infrastructure and government services could not adequately meet the demand of the private firms. Dissatisfaction was not evenly distributed across region. Generally, firms in Beijing were more dissatisfied. Their dissatisfaction rates were all above the average for all the kinds of information listed above. For example, 28 per cent of them (nearly 10 per cent above the average) said they felt it was difficult to get information on licensing and general government regulations. Sixty-four per cent (nearly 20 per cent above the average) said it was difficult get information on financial sources.

The rate of dissatisfaction was also high in Deyang for several kinds of information. The city that fared the best was Shunde where the dissatisfaction rates were in most cases below 20 per cent. In particular, only 6 per cent said it was difficult to get information on financial sources. Chengdu and Wenzhou followed Shunde in terms of general performance. Wenzhou scored higher also in financial information, with only 17 per cent expressing dissatisfaction. 
As for the reasons for the difficulties, a high proportion of CEOs indicated that the lack of intermediaries is the major obstacle. This may be more prominent in the financial sector about which the CEOs expressed the highest rates of dissatisfaction. China has a limited number of sources for a firm to finance its investment. Since the banks are very cautious in lending to private firms, and the stock market is almost exclusively reserved for SOEs, private firms have to turn to informal borrowing. For a large amount of borrowing, friends or relatives may be of limited help, and the search costs for a large lender are high.

On the other hand, investment tools are also limited to private choices. Bank savings and government bonds are not attractive in the current period because of low interest rates, and the stock market is too risky for many private entrepreneurs to try. To match effective projects and investors, investment intermediaries such as investment banks are indispensable. Yet China lacks these intermediaries and the government does not encourage their establishment. ${ }^{3}$

For the sources of information, it is interesting to find that firms rely heavily on non-government, non-commercial sources such as self-searching, mass media, and industrial associations. When asked how they obtained necessary information, 219 (65 per cent of the total) checked self-searching, 166 (49 per cent) mass media, and 142 ( 42 per cent) industrial associations. Only 85 (25 per cent) of CEOs checked government publications. However, 92 (27 per cent) $\mathrm{CEOs}$ pointing to the Internet as a source of information, indicating that the Internet's coverage in the six cities is relatively high.

The high reliance on non-government, non-commercial sources was found in firms' searching for specific information. When asked where they obtained information on their competitors, 179 (53 per cent) CEOs checked personal contacts, 127 (38 per cent) checked industrial associations, and 124 (37 per cent) checked mass media. In contrast, only 40 (12 per cent) CEOs regarded commercial information providers as a source of information about competitors. On a question of where the firms obtained business consultants, 138 ( 41 per cent) CEOs checked industrial associations and 98 (29 per cent) checked business networks.

However, 93 (27 per cent) also pointed to government as a source of advice. In contrast, only 46 (14 per cent) said local commercial consulting agencies were a source. Finally, when asked where they obtained training information, 131 (39 per cent) CEOs pointed to industrial associations again. Other significant sources included government 78, (23 per cent), educational and training publications 74 , (22 per cent), personal contacts 70 , (21 per cent), and mass media 68, (20 per cent).

Among the above findings, three are most interesting and relevant to the topic in this section. The first is that the government has played a significant role in providing consultation and training related information to firms, but has not done equally well in providing general information. In terms of the 
functions of the government, this may not be a bad thing. We do not expect a limited government to provide firms with their competitors' information or information on where to sell their products. The Survey question did not specify what kinds of consultation a firm gets from a certain source. Therefore, we do not know the kinds of consultation firms got from the government. Many CEOs expressed their appreciation to government-organised training classes.

The second interesting finding is that commercial providers have not begun to play a significant role in providing firms with information and consultations. One explanation to this finding is that specialisation is still low in the economy and the number of consulting agencies is limited. This explanation matches the fact that 44 per cent of the sample firms indicated that the lack of intermediaries was a major obstacle to acquiring information. Another explanation is that private firms cannot afford paying commercial providers because 17 per cent of the sample firms said that price was an obstacle to obtaining information.

The third interesting finding is that industrial associations have played a significant role in providing firms a whole range of information and consultation. From one perspective, industrial associations are a substitute for commercial information providers. From another perspective, the importance of industrial associations indicates that commercial networks are emerging and becoming a significant player in the Chinese private sector. We will devote the next section to the study of the types and functions of the business associations observed in the Survey.

\section{Business associations}

China has long maintained national industrial associations. These associations have played a significant role in helping firms exchange technical information and obtain technology-related consultations as well as setting national technical standards. This was clearly demonstrated in the description presented in the last section. In addition, some sample firms also pointed out that the industrial associations served as a vehicle for them to establish business relations. Because most of the associations are dominated by state firms, it is also helpful for a private firm to join the industrial association if it produces intermediate products that are used by state firms. However, entrepreneurs need localised organisations to coordinate amongst themselves as well as to handle their relationship with the local government. The Survey has revealed that such localised business organisations are emerging.

At the national level, there is an official Chamber of Commerce called All China Federation of Industry and Commerce (ACFIC). It has an extensive organisational network that covers all the government jurisdictions at or above the county level. It was first created in the 1950 s as a part of the Chinese Communist Party united fronts to accommodate private firm owners. During 
the Cultural Revolution, its activities were suspended. After it started again in the late 1970s, it gradually shifted its weight from old private owners to newly emerged entrepreneurs and gained popularity in many localities. Its main mission, especially for its national headquarters, is still to work for the Chinese Communist Party's united fronts and gain support from the private sector. Its presidents at various levels are appointed by the Party. However, it has also been engaged in providing more concrete services to its members. One of them is to work with Minsheng Bank to identify qualified private firms for unsecured loans.

Some local offices of ACFIC play a significant role in organising private entrepreneurs. In Sichuan Province, the provincial office of ACFIC is also called Sichuan Chamber of Commerce. The name change has meaningful implications because it has diluted the political colour of ACFIC. The new Chamber of Commerce provides a wide range of services to its members. It serves as a bridge between the private sector and the government by informing the former of government policies and regulations and by informing the latter of the suggestions of the private sector. It helps the private sector in several ways.

For example, it recommends good firms to banks with a view of reducing the efficiency losses associated with information asymmetry. It works with the government to grant technical titles to technicians working in the private sector, recommends promising firms to apply for funds issued by the national 'Star Plan' and 'Torch Plan', ${ }^{4}$ and helps private firms in obtaining passports and visas to facilitate their businesses abroad. It also has three specialised centres providing consulting services to members in the areas of firm management, legal affairs, and public relations.

In Shunde, townships that did not have an ACFIC office in the past have organised their own chambers of commerce. Those chambers are officially affiliated with the city ACFIC office, but the link is only nominal. Most chambers are established and run by private entrepreneurs themselves, but not without substantial government support. Box 10.2 shows the operation of the chamber of commerce in Guizhou township of Shunde. Interviews with private entrepreneurs in the township showed that they saw the chamber as a place to interact with each other and were quite pleased with the facilities and services it provided. The problem with the chamber is that it has restrictive conditions for entry, excluding smaller firms.

Interviews with local CEOs found that they formed different interactive circles by firm size. Smaller firms were in a disadvantageous position. They had the incentive to interact with larger firms to find opportunities for subcontracting from the latter, but larger firms had less incentive to reciprocate because there were enough small firms coming to their factories to ask for subcontracting. The interaction amongst smaller firms also was not commercial as many of them got together only to play majiang.

Another official organisation for private entrepreneurs is the Association of Private Firms. It does not have a national headquarters and is organised by the 
local BICM. Any private firm is eventually forced to join this association because the BICM collects the membership fee whenever a private firm is registered. The fee is also included in the annual firm examination. Although in some localities the president of the association is a private entrepreneur, more often, the president is a deputy director-general of BICM. Most private entrepreneurs interviewed regarded the association as useless to them and only a way of collecting fees from them.

In Wenzhou, industry-specific business associations are emerging. This happens because Wenzhou has several specialised national markets, such as small electronic parts in Hongqiao, low voltage electric products in Liushi, and buttons in Qiaotou. The longer history of Wenzhou's private sector also helps. Box 10.3 introduces the largest industrial association in Wenzhou, Wenzhou Garment Chamber of Commerce. This chamber has been very effective in providing services and interactions for its members. It has also done quite well in promoting Wenzhou's garment industry.

However, it has accomplished more than is normal for a chamber of commerce, and perhaps more than is desirable by promoting mergers amongst its members. Although it is in the members' interests, there is a problem of violating the nation's anti-trust law. ${ }^{5}$ Nevertheless, in an environment short of law enforcement, this behaviour is tolerated and even promoted by the local government because it is also in its interest to have a stronger local economy.

The promotion of industrial mergers is no more evident than in the case of the Qiaotou Button Chamber of Commerce in Yongjia county. Qiaotou is a town specialising in button production and wholesaling. It has 750 firms producing buttons. When the chamber of commerce was founded in 1996, its main purpose was to reduce the fierce competition amongst small button producers. Buttons are easy to produce, and new styles can be easily imitated. To protect firms with innovations, the chamber has enacted and enforced a regulation called Regulations on Protecting and Managing New Products. Member firms can apply for protection of new products for two or three months. The fee for two-month protection is 1,500 yuan, and for three month protection, 2,000 yuan. The short period of protection is consistent with the rapid design replacement in the button industry.

The chamber regularly checks the market to find imitations of the products under its protection. The violator is first warned to stop producing and selling the product; if it continues the violation, the chamber informs the township government, and the latter takes on the case and punishes the violator. The township government takes local chambers of commerce seriously. The mayor of the township is the honorary president of the button chamber, and there is a government department coordinating its relationship with the chamber. For members who violate the regulation, the button chamber can itself issue punishment. Since the chamber has gained high popularity, the township government also entrusts the chamber to punish non-member violators. 


\section{Box 10.2 Guizhou Chamber of Commerce}

Guizhou is a town in Shunde. It is completely connected with another town Rongqi. The two towns form the largest industrial site in Shunde. The Guizhou Chamber of Commerce was founded in September 1994. The town did not have a local ACFIC local chapter before the chamber was founded. Membership is restricted to firms above a certain size and has to be recommended by villages. Because of the restriction, the chamber only has some 100 members. The annual membership fee is 360 yuan. The township government provided 80,000 yuan when the chamber was founded. Daily operation relies on the membership fee and member donations.

The president and the board of directors are all private entrepreneurs. The board holds a meeting every month. Daily management is handled by a permanent office of two people. One of them was the principal of the town's high school, and the other worked in several government departments before. As a result, they maintained good relations with the government. They are responsible for inviting government officials, the mayor of the town, the head of the local tax bureau, etc., to participate in the board meetings.

There are two major events for the chamber in a year. One is the all-member meeting, and the other is the Spring Festival. In addition, one major activity of the chamber is to organise members to have tours of other parts of the country and to provide training information to entrepreneurs. The chamber also publishes a monthly newsletter that is mailed to every member free. The newsletter publishes related local and national news, news on government regulations, and articles written by local entrepreneurs. It serves as a bridge between the chamber and its members. The office maintains records of government documents and put a notice in the newsletter when a new document is received.

The chamber also helps individual firms when dealing with the government and legal affairs. For example, one firm did not fill in one bunch of its material receipts in the right way, so the tax official in charge was not willing to take these receipts into the calculation of the firm's value-added tax base. The chamber then talked with the head of the tax bureau and resolved the problem. In another example, the chamber helped another firm win a lawsuit in another province.

The chamber intended to construct its own building when it was founded, and the township government also gave it a piece of land. However, the building has not been constructed because of shortage of funds. The chamber intends to construct the building in the future after the economy improves and its members make more cash income. Two other major tasks the chamber is undertaking are to work with the government to issue technical titles to qualified technicians in private firms and to get multiple-entry visa for private entrepreneurs. 
The button chamber is in effect a semi-government agency. The interesting question, then, is why the township government does not use its own resources to promote new product protection? This question can be answered from two perspectives. First, the current patent law does not provide good protection of style-based new products. This is natural because the enforcement of such a protection is very costly. Therefore, there is not a good reason for a local government to provide the protection. As such, the button chamber's own regulation becomes a substitute for the national law. Although it was intended to govern its own members, it has effectively become a local law after it has been recognised by the local township government (or, the government enacted the regulation itself).

Second, the chamber of commerce may have an advantage over a government agency in enforcing a regulation on numerous small firms. The potential advantage derives from the established business network in the button industry.

\section{Box 10.3 Wenzhou Garment Chamber of Commerce}

The garment industry is a 10 billion yuan business in Wenzhou. The garment chamber was founded in March 1994 by a group of private entrepreneurs engaged in the garment business. It has five self-management principles: voluntary participation, democratic election, self-internal management, self-financing, and paying membership fees. Membership fee is between 300 to 500 yuan per year. A member conference is held once a year. It elects the board of directors, and the directors elect the president and vice president. The cost of the conference comes from donations of the directors. It maintains an office for daily operation. Employees of the office are paid by its own funds. The daily operation of the chamber also partly relies on member donations.

The chamber has done quite well in promoting Wenzhou's garment industry. It publishes a journal Wenzhou Garments, providing information to its members and also introducing Wenzhou garments to outsiders. It organised its members to participate in several garment exhibitions, and organised two Wenzhou International Garment Exhibitions in 1997 and 1998. It helps its members improve the quality of their products by organising training classes and facilitating members to participate in provincial and national quality examinations. In 1996, 8 firms participated in a quality examination organised by Z hejiang province, and 7 were awarded with 'Quality Brand'. The chamber promotes cooperation and mergers among its member firms. Several mergers have happened and the new companies are enjoying larger market shares in certain product niches. It also helps members when they have unanticipated difficulties. For example, when a member's factory was severely damaged by a hurricane, he used member donations to rebuild his factory. Finally, the chamber maintains regular contacts with the city government. A vice-mayor of the city is the honorary president of the chamber. It cooperates with government branches to enforce technical standards as well as government regulations. 
However, the question can be posed; why does the chamber of commerce itself need the local government's help to enforce its own regulations? One answer to this question is that there is a problem of free riding that cannot be solved by the chamber itself.

In particular, free riding of non-member firms is a serious threat to the sustainability of any regulation that only governs member firms. In this case, it is imperative for the chamber to obtain the government's assistance. Alternatively, the local government's assistance provides authority to the chamber when it tries to enforce its regulations on members. The chamber of commerce is a voluntary organisation, so the existence of free exit reduces members' incentive to abide by its regulations. The recognition by its members of government authority helps pull the chamber together. However, China should prevent such associations from becoming the source of monopoly power favouring a few entrepreneurs to the cost of small businesses and consumers. These possible negative aspects should be emphasised.

Business networks provide public goods to enhance the development of the private sector. They also provide an institutionalised infrastructure that fosters the formation of a proper business culture. Through the above examples, we have seen that the essential element of a business network, business associations, is emerging to respond to the needs of private firms. The interaction between a business association and the local government is the most interesting feature found in the study and can be understood as a choice of both the private firms and the government responding to China's imperfect market and institutional environments.

\section{Room for improvement}

The discussion in this chapter suggests several recommendations for improving the laws and regulations related to private firms and the performance of the administrative management.

While several of the shortcomings of Chinese laws related to private firms are derived from the weak law and regulatory enforcement, and are not likely to be remedied in the short-run, two improvements are immediately possible. First, firm registration should be changed from an approval process to a true registration process. At least, the minimum requirements for the initial capital should be dropped. Currently, these requirements are not binding constraints if firms are willing to cheat because they can borrow money from friends and return it immediately after they receive approval. They are only binding for firms that do not want to cheat. Therefore, these requirements lead to adverse selection by promoting cheaters and punishing honest people. 
Second, the division between a getibu and a private firm should be dropped. The division is arbitrary in the first place, and creates an asymmetric incentive that induces a private owner to remain as getibu for the purpose of tax minimisation. In addition, the TSRIPE has to remain in place in order to accommodate the division, so the integrity of the Chinese laws is harmed. Since the only reason for it to remain in place is local BICMs' interests, the division should and can be eliminated.

Administrative performance is closely linked with government size and structure. With excessive public employment and redundant departments (such as the Bureau for TVEs in Wenzhou), rent-seeking behaviour is encouraged. For example, the central government has issued many directives calling for stopping irregular fees and reducing regular fees, but the amount of fees has still ballooned in the country. With tight budget constraints, local governments have to find new income sources to sustain a large government. In many cases, they have to keep silent on their employees' rent-seeking behaviour. Therefore, a thorough government reform is imperative for the restructuring and downsizing of local governments.

The Shunde municipal government has set a good example in this aspect. The current government reform, if implemented properly, would achieve the same effects generally as are present in Shunde. The reform carried out in the central government has radically reduced the number of ministries, by 19 , but fallen short in cutting down the number of employees that are covered by the state budget. Many of the employees who lost their positions in a functional department have been relocated to a non-functional unit (such as a research institute) affiliated with a ministry.

Since local governments do not have as many non-functional units as the central government, one possibility is that downsizing will be forced to be real by releasing redundant employees out of the government sector. Yet another possibility is that local governments will have to create more non-functional units to accommodate the laid off employees, or the reform will simply stop. Which direction the reform will take depends on local governments' determination.

Finally, law and regulatory enforcement is the hardest part to change. This is because law and regulatory enforcement not only requires large amounts of resources, but also requires a change of people's attitudes toward the rule of law. However, there is still room for improvement. Law and regulatory enforcement is largely related to the quality of the law enforcement and administrative agencies in the government. For example, the public security bureau asks for a substantial amount of fees for taking a case. Therefore, improving the quality of the public offices is directly linked to the kind of government reform that was implemented in Shunde. 


\section{Social consciousness and channels for private entrepreneurs' voices}

The orthodox ideology in China still regards private entrepreneurs as exploiters of their employees. Officially, a Communist Party member is forbidden to become an owner of a private firm. Yet in reality, many private owners are members of the CCP. This has caused confusion amongst the private entrepreneurs with party membership and in some cases diminishes their incentives to enlarge their operations. To some extent, the new policy toward the private sector formed in the Fifteenth Congress of the CCP and the subsequent constitutional amendment provided an assurance to these private owners.

However, the risk is still there as the party has not taken back the prohibition and the constitution lacks the clause of unconditional protection of legal private properties. Therefore, although it has been taken as an unarguable fact that private firms have become an indispensable factor for Chinas economic development, the government is still reluctant to give private owners full recognition.

On the administrative side, the government has been slow in moving from a system comparable with a planned economy to a new system compatible with a market economy. Generally, the government is very effective in management revolving around its current bureaucratic establishments, but much less so in handling issues outside its traditional bureaucratic sphere.

A market economy requires more horizontal co-ordination and arbitration than vertical bureaucratic management, yet the government structure has been largely geared to accomplish the latter task. This is no more obvious in the lack of effective law enforcement for business contracts. Related to the bureaucratic establishments are the explicit and implicit rules governing the behaviour of public servants. Different bureaucratic establishments produce different rules which in turn would influence the performance of the economy. The sum of the bureaucratic establishments and the explicit and implicit rules affiliated with them is the so-called institutional capital that has been used to explain the failure of the privatisation program in Russia (Stiglitz, 1998).

China has been slow in transforming its institutional capital. This has largely to do with its gradualist approach to economic reforms. Because the latter has progressed slowly, the demand for new institutional capital is weak. However, as the private sector emerges as a major player of the economy, the demand for new institutional capital is rising. The role of institutional capital can be illuminated by comparing Shunde and Wenzhou.

In Shunde, the government took an administrative reform hand-in-hand with its privatisation program as early as 1993 . The central theme of the reform was to transform the role of the government from the manager of the economy to the arbitrator of the economy. To accomplish this task, it radically cut the 
total size of the staff in both the government and the party offices from 1,400 to less than 900 . Accordingly, it reduced the number of government and party departments from 49 to only 29. As a result, many departments in charge of managing the economy vanished. For example, there were 14 bureaus in charge of agriculture before the reform. Now there are only 4 . In addition, the several bureaus in charge of industry were shrunk into one, and its role has been largely transformed from management to providing services.

After the reform, governments at all levels have adopted a hands-off policy toward the economy. Instead, they have been more focused on law and regulation enforcement that aims at creating a fair business environment for all firms. In the meantime, the morale of government officials has been rectified. A new consensus has been formed regarding the role of public servants. They are not players in the game, but arbitrators and service providers. All these factors have contributed to forming a new kind of institutional capital that is amiable to a private-ownership based market economy.

The success of Shunde's privatisation program had much to do with the government reform. Privatisation allows private entrepreneurs the right to make decisions and gain legal ownership of the firms. However, it does not prevent rent-seeking behaviour by offices of government. In an environment of weak law enforcement, it does it prevent the government from encroaching on private ownership. With radical government reform, the Shunde government sent a strong signal to private entrepreneurs that it was committed to protecting private ownership because, willingly, it had cut its own power and the base for rent-seeking (Yao and Zhi, 1999).

In a broader context, Shunde's government reform sent a message to the general public that the municipal government held the belief that private ownership was the better choice to improve social welfare. Because of the strong role of the government in contemporary China, the opinion of the general public is largely influenced by government's position. Therefore, in the case of Shunde, the message sent by the government reform has also played a role of a catalyst in the formation of social capital that is amiable to the privatisation program and to private ownership in general.

In comparison to Shunde, Wenzhou has a much longer history of a private economy, yet it does not have the proper institutional capital that is comparable with that economy. The research team found that the Wenzhou government still maintains the structure inherited from the past. For example the government department called the Bureau of Township and Village Enterprises whose task is to manage and regulate TVEs. There are very few TVEs. Soon there will be no TVEs in Wenzhou. Although the government also adopts a hands-off policy towards the economy, the existence of the excessive functional departments propels them to find a reason for their existence. 
The struggle between different government departments trying to control the same enterprises is a consquence of the old structure. For example, the Bureau of TVEs fights with the city BICM for the control of private enterprises because getting control means obtaining the right to collect the management fees on these enterprises (Chapter 10). To maintain these departments, the government turns a blind eye to arbitrary behaviour in legal enforcement. It is common in Wenzhou to find government employees operating their own businesses under alternative names. The mixing of government employment and personal businesses, if has not brought corruption, has at least ruined the work spirit of the public servants.

It is not surprising to find that more of the sampled private CEOs in Wenzhou complained abour the government's arbitrary behaviour than those in Shunde. The research team also found that some firms in Wenzhou moved to Guangdong because of the high land price and unfriendly institutional environment.

While the institutional capital largely defines the institutional environment for a private firm, the social capital defines a private entrepreneur's position in society. The general public's perception of a private entrepreneur has changed over time and varies between regions. Private entrepreneurs were thought to take advantage of employees until recently. However, the general public still perceives private firms as being less trustworthy than state firms. This is partly caused by prejudices, the relatively poorer quality of products (especially consumer products) produced by private firms and their unwillingness to disclose internal information.

It is very interesting to observe that many private entrepreneurs sought to de-emphasise the private nature of ownership of their firms. They argued that private capital is a part of the capital a society owns, and its accumulation is the accumulation of society's capital. However, government officials did not agree. Their logic is simple - capital accumulated by a private firm belongs to the owner itself, but capital accumulated by a state firm belongs to the public. While this logic is correct, it also leads to different treatments for private and state firms. For example, the funds invested by a state firm in technical innovations are exempted from corporate income tax, but a private firm does not have this privilege. When asked by a private owner, a government official defended the policy by exactly the same logic. In light of the different treatments and negative perception of the general public, it is understandable why private entrepreneurs asked that their ownership be 'de-emphasised'.

It is noticeable that people in different regions have different perceptions of private firms. In the coastal areas, people are more tolerant towards private entrepreneurs; but in central and western parts of the country, accumulation of private wealth will cause others envy. This may be more prominent in a village setting where people form a close-knit society and the collective survival mentality implanted by the commune system still has its influences. 
There are also differences between the south and the north. When the research team visited the BICM of Beijing, it was clear that private firms included all the three kinds of ownership types, that is, sole ownership, partnership, and limited liability. However, when the team visited the BICM of Shunde, it was told that only a firm of sole ownership was categorised as private. Indeed, according to the published statistical yearbook of Shunde, public firms, state-owned or collectively owned, still dominated even in 1997 whereas in reality there were only a few such firms by that year. The reason for this discrepancy was that partnership and limited liability firms were recorded as public. It was a result of the de-emphasis of private ownership, and consistent with the low profile the Shunde government has maintained for its privatisation program. In effect, it has helped the private firms in Shunde to gain confidence as well as to obtain a shield to potential criticisms.

What is the response of a private entrepreneur to harsh environments? The unfriendly environment has taken a toll on the private sector. Not long ago, it was not hard to find a private entrepreneur engaging in excessive consumption, pouring a fortune into building a mansion, buying luxurious cars, having exotic banquets, or in the extreme case, simply competing to burn more renminbi notes. The state did not provide sufficient protection to privately owned production means, but did protect individual belongings including houses and cars. Therefore, this excessive consumption was, to some extent, a way of moving one's wealth from the sphere without sufficient protection to that with full protection.

Another way for a private entrepreneur to protect business assets was to put a ted hat on its head, that is, to guakao a collective firm or a local government branch (see Box 4.1 for an example). However, things have gradually changed in recent years. As the state becomes more tolerant of private firms, the social capital also becomes more accommodating. On the other hand, private entrepreneurs have become more mature. In Shunde, it is common for a group of entrepreneurs to order simple meals for dinner while they discuss business.

More and more, private entrepreneurs have begun to voice their concerns by participating in public life. Many of them hold positions in local and national People's Congress or People's Consultative Congress. It was frequently found by the research team that the voice of private entrepreneurs in these two legislative bodies made a difference.

One prominent example involves an entrepreneur of a large software company in Beijing. He is a deputy of the National People's Congress. $\mathrm{He}$ proposed in one session of the Congress to cut the value-added tax rate of high-tech firms from 17 per cent to 8 per cent. The proposal was eventually passed. It is noteworthy that the promotion of the national ACFIC and its local chapters should be fully accredited for the engagement of private 
entrepreneurs in China's political life. As a private entrepreneur has to be recommended by a local ACFIC chapter in order to take a position in a legislative body, the role of ACFIC in promoting the political stance of the private sector is indispensable. However, despite the official background, the active engagement of private entrepreneurs in public life has reinforced their identity and self-consciousness. A new business class is taking shape in China.

\section{Notes}

1. The central government finished its reform in 1998 and cut 15 per cent of its employees and consolidated a dozen of ministries. The same percentage cut is required for local governments. Therefore, the actual cut in Shunde was more than 2 times the required cut.

2. The numbers in the parenthesis are the percentage and firm numbers with usable entries.

3. The National Bank of Development intended to set up an investment bank, but the idea was put down by the State Council.

4. The 'Star Plan' aims at promoting small firms; and the 'Torch Plan' aims at promoting high-tech industries.

5. China does not have a separate anti-trust law, but the Anti-Unfair Competition Law has clauses regarding the issue. 


\section{References}

Bo, Y., 1991. Review of Several Important Decisions and Events, Zhongyang Dangxiao Press, Beijing.

Che, J. and Yingyi Q., 1998. 'Insecure property rights and government ownership of firms', Quarterly Journal of Economics, 113(2): 467-96.

Fernald, J.G. and Babson, O.D., 1999. 'Why has China survived the Asian crisis so well? What risks remain?', Laws and government administrative regulations 137 Board of Governors of the Federal Reserve System, International Finance Discussion Paper 633.

Gao, S., 1998. 'Enterprise arrears in the last ten years', Manuscript, People's Bank of China.

Gregory, N., Tenev, S. and Wagle, D., 2000. China's Emerging Private Enterprises: Prospects for the New Century, International Finance Corporation, Washington DC.

Hasenstab, M., 1999. 'Financial system reform and implications' in R. Garnaut and Ligang Song (eds), China Twenty Years of Reform, Asia Pacific Press, Canberra: $117-48$.

Li, D., 1996. 'A theory of ambiguous property rights in transition economies', Journal of Comparative Economics, 23(1):1-19.

Li, S., 1997. 'Rural migrants and income distribution', Manuscript, Institute of Economics, CASS.

Li, S., 1997. 'The institutional foundation of self-enforcing contracts: the township enterprises', Mimeo., Department of Economics and Finance, City University of Hong Kong.

Lin, J.Y., 1992. 'Rural reforms and agricultural growth in China', American Economic Review, 82(1):34-51.

Lin, J.Y. and Yao, Y., 1998. 'Chinese rural industrialisation in the context of the East Asian miracle', in J. Stiglitz (ed.), Rethinking the East Asian Miracle. World Bank, Washington DC.

Ren, P., 1999. 'A report on the taxation and fees in Zhangjiajie city', Manuscript, Institute of Finance and Trade, CASS.

Schlevogt, Kai-Alexander., 1999. 'Deflation necessitates micro-adjustment in China', China Daily Newspaper, October 8.

Song, L., 1998. 'China', in R. McLeod and R. Garnaut (eds), East Asia in Crisis: from being a miracle to needing one?, Routledge, London:105-19. 
State Statistical Bureau of China (SSB)., 1999. China Statistical Brief, The Statistical Press, Beijing.

Stiglitz, J., 1998. 'The next step of China's reform', lecture given in CCER, Beijing University, Beijing.

Wang, X., 1999. 'A view on China's economic growth in the past and future', Manuscript, National Economic Research Institute.

Wang, Y. and Yao, Y., 1998. Technology Acquisition Capabilities and Development of China's Small Enterprises. Paper prepared for Final Workshop on Small \& Medium Enterprises in East Asia, organised by the World Bank Institute (WBI).

$\mathrm{Xu}$, S., 1999. 'China's taxation system and regional tax rights: defining regional tax rights under fenshuizhi', Manuscript, Bureau of Taxation, the State Council.

Yang, Z., 1998. 'An analysis of Chinese government income', Jinji Shehui Tizhi Bijiao (Comparative Economic and Social Systems), 5:17-23.

Yang, Z. 1999. Public Finance: Theory and Practice, Shanghai Renmin Press, Shanghai.

Yao, Y., 1999. 'The division of taxation rights: conundrum to further reforms' Manuscript, China Center for Economic Research, Beijing University.

Yao, Y., 1999. Land tenure and rural social security in China. Paper presented in the International Symposium on Unemployment and Social Security in China, Chengdu, July 1999.

Yao, Y. and Zhaohua, Z., 2000. 'The role of government and privatisation', Jingji Yanjiu (Economic Research), 2000(1): 3-10.

Yi, G. and Zhao, X., 1998. 'To search for effective policy combinations under multiple economic objectives', Jingii Yanjiu (Economic Research), 1998(4): 3-11.

Zhang, H. and Lit, W., 1995. China's Private Economy and Private Entrepreneurs, Zhishi Press, Beijing.

Zhao, X., 1999. 'Competition, public choice and institutional change', mimo, China Center for Economic Research (CCER), Peking University, Beijing. 


\section{Index}

$15^{\text {th }}$ Congress of CCP $15,46,132$ $26^{\text {th }}$ document 106

ABC (Agricultural Bank of China) 59,69

accounting books 64

ACFIC (All China Federation of Industry and Commerce) 5, 62, 125 , 126,136

adjustment tax on capital investment 80

Agricultural Bank of China (ABC) 59,69

agricultural production (see farming system)

agriculture (see also farmers)

as private $16,27 \underline{n} 8$

GDP share 17,19

restoration of farming system 1 tax bases 81

All China Federation of Industry and Commerce (see ACFIC)

annual reports, provision of 93,94

Anti-Unfair Competition Law 136n5

ANU (Australian National

University) 2

arrears (see enterprise arrears)

Asian financial crisis 42

Asia Pacific School of Economics and.

Management (APSEM) 2

asset appraisal $63-64,70,76-77$ asset evaluation system xvi

Association of Private Firms 126

Australian National University (ANU) 2

bad debts (see enterprise arrears)

bank loans (see finance; loans)

Bank of China 59

Beijiao 111

Beijing

1989 fracture 14

business partners 49

capital growth rate 37

collateral $62-64$

education facilities $109 \underline{\mathrm{n}} 2$

employment 37

enterprise arrears 56

Firm P (case study) 121

firm profitability 38,40

firm size (capital stock) 37

firm size (no. of workers) 32, 33, 34,41

firm size (sales and capital) 34 35,36

Firm Y (case study) 63

getihu fees 119

industries 35

information dissemination 123

initial capital $53-54,55,58$

land acquisition 120-121

laws and regulations 120-121

listed firms 96

loan applications 59-60, 61, 63

managers' education 100-101, 102

managers' experience 103

market barriers 44, 45, 46

ownership 90

partnership firms 91

population control 109쯔 
private firms 135

private sector development 2930

profile 29

public services $122-123$

'red hat' firms 14, 46

resident status 105

social security contributions 107 , 108

survey criteria $2,4,5,6-7,8 \underline{\text { n}} 8$

taxation 85,87

technological innovation 111, 112

technological piracy 51

turnover rate $57-58$

wage rate $105-106,109 \underline{n} 4$

W Arts Co. Limited (case study)

46

workforce 98

BICM (Bureau of Industry and

Commerce Management)

business licenses 44-45

capital registration criteria $41 \underline{n} 2$

database $5,8 \mathrm{n} 8$

fee collection 119, 127

firm registration 118

statistics 16

survey participation 3

'bleeding' 21

budgetary income 82

Bureau of Industry and Commerce

Management (see BICM)

business associations $125-130$

business partners $48,49,92$

buttons (see Qiaotou Button

Chamber of Commerce)

capital

firm size and 34-35, 36

foreign sources of 54 initial 53-54, 55, 58

ownership distribution and 25

stock market as source of 68 working 57-59, 66

capital growth rate 37

capital investment, adjustment tax on 80

capitalist production process, Marx's definition 13

capital registration criteria $41 \underline{\mathrm{n}} 2$

capital stock growth rate $37-38$

case studies

Bank finance in Wenzhou $69-70$

Changing ownership and internal governance in private firms 95 derivation of 4

Fees collection and government corruption 88

Firm J's journey to get a bank loan 48,70

Firm P's loss of its land 121

Firm S's local taxes and fees 87

Firm TZ 95

Firm Y's journey to get a bank loan 63

Gaizhi in Sichuan province 23

Guizhou Chamber of Commerce 128

HDL 116

Intellectual property rights and technical innovation 116

MD: Development by way of innovations 111 (see also MD)

Shunde's privatisation 22

W Arts Co. Limited 46

Wenzhou Garment Chamber of Commerce 129

$\mathrm{CBC}$ (Construction Bank of China) 59,69

CCER (China Center for Economic Research) 2 
CCP (Chinese Communist Party)

$15^{\text {th }}$ Congress $15,46,132$

ACFIC as part of 126

enterprise reform policy $27 \underline{n} 11$

presence in firms 99

sanctioning farmers' initiatives

$11,28 \underline{n} 2$

socialist transformation and 9

Central Bank, interest rates xxiii

centralised purchases and centralised

sales, policy of 9-10

chambers of commerce 125-126, $127-130$

'changing the ownership structure'

(see gaizhi)

Chengdu (Sichuan Province)

arbitrary fee imposition 87

education facilities $109 \mathrm{n} 2$

firm profitability 40

firm size (no. of workers) 32, 33,

34,41

firm size (sales and capital) 36

guarantee funds 72

Hong Kong finance 71

industries 35

information dissemination 123

initial capital $53-54,55$

listed firms 68

loan applications 61

managers' education 101,102

managers' experience 103

market barriers 45

outside expertise 95

ownership 90

private sector development 31

profile 29

public services $122-123$

social security contributions 108

survey criteria $2,4,5,6-7$

taxation 85,87 technological innovation 112

turnover rate $57-58$

wage rate $105-106,109 \mathrm{n} 4$

China, People's Republic of

constitutional amendments $\mathrm{xi}, 15$

founding 9

historical perspective $42-43$

socialist transformation 9-10

China Center for Economic Research (CCER) 2

Chinese Communist Party (see CCP)

City Credit Union 64

collateral (see also collateral appraisal)

formal loans 62

informal loans 66

collateral appraisal $63-64,70,76-$

77 (see also collateral)

collectives $14,17,19$

communes 10

Communist Party (see CCP)

conglomerates $97-98$

constitutional amendments xi, 15

Construction Bank of China (CBC) 59,69

consumerism 12,135

cooperatives, emergence of 10

corporate income tax $78-79,81,83$ 84,85

corporations, requirements for $99 \underline{n} 4$ corruption 88

credit associations $67-68$

credit unions 53-54, 64, 65, 66

Cultural Revolution 10, 11, 126

Das Kapital (Marx) 13

database development $5,8 \underline{n} 8$

dead payments 50 (see also enterprise arrears)

Decisions on Establishing a Unified Basic Enterprise Pension System 106 
deflation

Asian financial crisis affecting 42

causes $43,51 \mathrm{n} 2$

consumer demand and 43

economic growth affected by 43

Deng Xiaoping 15, 23

Deyang (Sichuan Province)

fee rate 85

firm profitability 40

firm size (no. workers) 32, 33, 34

firm size (sales and capital) 36

industries 35

information dissemination

123

initial capital 53-54, 55

loan applications 60,61

managers' education 102

managers' experience 103

market barriers 44,45

public services $122-123$

survey criteria 5,6

taxation 85

technological innovation 112 , 113

turnover rate $57-58$

wage rate $105-106$

domestic private enterprises, defined $8 \mathrm{n} 1,17$

Dongguan 31

early retirement schemes 94

economic growth, regional disparities 24, 26-27

economic reform xi-xiv, xxii

economy, private sector contribution

to $15-27$

education

firms cooperating with institutes of $112-113$

managers' profiles $100-104$
MBA programs 104-105 policy recommendations xxi training 104-105, 108, 114 universities $101,109 \underline{\mathrm{n}} 2$ workers' profiles 101, 104 electricity 122 employees (see workers) employment (see also unemployment) corruption penalising 88

firm size and $31-34$

high taxes affecting 86 in Beijing 37

in private firms $24,25,26$

in Shunde 37

of rural migrants 98

of urban workers 98

private sector's share 16

enterprise arrears $50,54,56-58,81$

enterprise bonds 66

entrepreneurs

collectives rented by 14

government support for 15

environment protection bureau 88 , 89

extra-budgetary income 82

farmers (see also agriculture)

enterprise arrears and 57

non-agricultural activities by 1 , $27 \mathrm{n} 2$

farming system, restoration of 1

fees (see also taxation; value-added tax)

arbitrary imposition 87,89

burden distribution 84

centralised control of 86

collection 81,88

complaints about 85

Firm S (case study) 87

for collateral appraisal $64,70,76-$ 77

for getihu 119 
government corruption and (case study) 88

land price influenced by 30

policy recommendations xvii-xviii proliferation of $79,81-82$

fenshuizhi system 78

Fifteenth Congress of CCP 15, 46, 132

finance

Bank finance in Wenzhou

(case study) 69-70

Firm Y (case study) 63

formal loans 59-66, 74ㅆ2, 75-77

informal loans 66-68

overseas sources $70-71$

overview of survey firms $53-$ 59

policy recommendations xivxvi

reform measures xiv-xvi, 7173

stock market as source of 68 , 70

financial reform xiv-xvi, 71-73

Firm J (case study) 48, 70

Firm P (case study) 121

firms

capital stock growth $37-38$

defined for GDP 17

listed on stock exchange 96

management of 92-96

profitability 38,40

registration $117-120,130,132$

state ownership 20

state's disposal of 20

technical capacities 113-114

Firm S (case study) 87

firm size (no. of workers)

employment and 31-34

geographic distribution $32-34,41$ growth rate and 41

loan applications by 61

market barriers 47

profitability and 40

taxation 84

technological innovation and

110-112

wage rate and 106

firm size (sales) 36-37

firm size (sales and capital) 34, 35, 36

Firm TZ (case study) 95

Firm Y (case study) 63

five-year plans $10,27 \underline{\mathrm{n}} 12$

foreign banks 71

foreign capital 66

foreign investment, adjustment tax for 80

foreign ownership, in GDP 17

foreign trade

chambers of commerce assisting

126

licenses for xiii, 45

offshore guarantors 62

gaizhi

as official collectives 17

defined 20-21

initial capital of 53

privatisation and $20-21$

Sichuan province (case study) 23

GDP (gross domestic product)

1993 growth 42

1997 growth 42

composition of 17

ownership shares 19

private sector's share 16-17

tax contribution 82

General Guidance for the Transitional

Period, The 9

General Lending Rules 75 
geti gongshang hu (see getihu)

getihu

1987 survey 14

1989 decline 14

1990 's increase 15

as domestic private enterprises 17

defined 13

development of 11-15

fees for 119

registration of 117,119

taxation $81,120,131$

governance, internal (see internal governance)

government income 82

government reform xix, xxii, 136ㅁ1

Grand 31

Great Leap Forward 10

gross domestic product (see GDP)

guakao 44, 46, 135

Guangdong 4, 31 (see also Shunde)

Guangzhou 22, 45

guarantee funds 72

Guizhou Chamber of Commerce (case study) 128

HDL (case study) 116

healthcare 107-108

Hebei 14

Hong Kong

as foreign finance source 71

MD listed 111

stock market 59, 71, 74n 4,95 ,

111

subsidiaries in 43

Hongqiao 30,32

Hope Group 31

ICBC (Industrial and Commercial

Bank of China) 59, 69

ideology 132, 134
IFC (International Finance

Corporation) xxii, 2

income, government 82

Industrial and Commercial Bank of China (ICBC) 59, 69

industrial associations (see business associations)

industrial output, of private sector 18 industries

categories $31,35,36$

geographic distribution 32,35

profitability 39,40

informal market, as source of finance 66-68

information asymmetry $64,66,118$ information dissemination $\mathrm{xx}, 123$ 125

institutional capital 132-133, 134

intellectual property rights 113,115 116

interest rate

borrowing behaviour and 73

for formal loans xxiii, 59, 65, 66, 72

of informal market 67

Wenzhou as experimental zone

69-70

internal governance

decision making 92-96

employee involvement in 96,98

industrial organisation and 96 98, 99

labour management 98-99

ownership forms 90-92

International Finance Corporation (IFC) $\mathrm{xxii}, 2$

Internet 124

investment

adjustment tax for foreign 80

incentives for 124 
policy recommendations xxi-xxii issue of equity 66

Jintang 23

judiciary system 56, 57 (see also laws and regulations; legal system)

'keep the large ones and let go the smaller ones', policy of 20

Kelong 22, 31

labour disputes 98, 99

labour market 98

labour skills 100-105, 108

land

as collateral 62

as social security 108

compulsory acquisition of 121

loss of by Firm P (case study) 121

non-ownership by occupier 62-

63

ownership non-acknowledgement

11

price in Wenzhou 30

use rights $22,63,85-86$

Law of Corporation $13,91,99 \mathrm{n} 4$

Law of Incorporation $27 \mathrm{n} 12,117,118$

Law of Partnership Firms 117, 119

Law of Private Sole Ownership Firms 117,119

Law of Protections on Small and Medium Size Firms 117

laws and regulations (see also individual laws; judiciary system; legal system)

administrative performance 122 123

business associations $125-130$

for private firms $117-120,132$

information dissemination 123 -

125 regional differences 120-121, 132 suggested improvements 130 133

legal system, policy recommendations $\mathrm{xx}$-xxi (see also judiciary system; laws and regulations)

Liaoning 14

limited liability companies

benefits of $23,91-92,99 \mathrm{n} 2$

firms' share 25

geographic distribution 91

laws governing 13

registered capital of $24,41 \underline{n} 2$

rise of 23

types of $27 \underline{\mathrm{n}} 12$

listed firms 22, 68, 71, 95, 96, 111

(see also stock market)

Liushi 30,32

loan guarantee funds xvi

loans (see also finance)

access to 43, 59-66, 124

Central Bank policies 75

for technical innovation 114

informal $66-68,124$

interest rate 59

policy recommendations xiv-xvi

private sector utilising 16,53

macroeconomic conditions, historical perspective $42-43$

management buy-out (MBO) 22

management leasing 22

management of firms $92-96$

managerial skills $100-105,108$

market barriers 44-45, 47, 118 (see

also market entry)

market competition (see also enterprise arrears)

competitors $46-48,50-51,51 \underline{n} 5$

dead payments 50

Firm J (case study) 48 
historical perspective $42-43$

networks 49

partners 48, 49

profitability and 38

technological innovation and 114

W Arts Co. Limited (case study) 46

market economy, requirements of 132

market entry

barriers $44-45,47,118$

openness and requirements $43-$

46

restricted businesses 52

restrictions 43-45

W Arts Co. Limited (case study)

46

marketing 49

Marx, Karl 13

MBO (management buy-out) 22

$\mathrm{MD}$

case study 111

listed firm 22, 71

products 31

wage rate 104

workers' education levels 101, 104

medicine distribution 44-45

methodology of survey $2-4,8 \underline{n} 3-\underline{n} 4$

Mianyang (Sichuan Province)

fee rate 85

firm profitability 40

firm size (no. workers) 32, 33, 34 firm size (sales and capital) 35, 36, 37

industries 35

initial capital 53-54, 55

laws and regulations 120

loan applications 61

managers' education 102

managers' experience 103 market barriers 45

ownership in 90

public services $122-123$

survey criteria 5,6

taxation 85

technological innovation 112 , 113

turnover rate $57-58$

wage rate $105-106$

Minsheng Bank 72, 73, 126

monopolies, market barriers causing 44-45

Nanhai 31

networks, commercial 49, 125, 130

New York Stock Exchange 74n 4

Ningxia 14

non-budgetary income 82

output, private sector's share 16

outside directors (see outside expertise)

outside expertise 94-95

overseas finance $70-71$

ownership

forms of 90-92

geographic distribution 91

industrial organisation and 97

management and 92-96

registration of 23

partners, business $48,49,92$

partnership firms

benefits of $91-92,99 \mathrm{n} 2$

firm size and 25

laws governing 13

relative importance of $23-24,25$

taxation 120

patents 111,115

Pearl River Delta 4 
Peking University 2

pension schemes 106-108

People's Congress 135

People's Cosnsultative Congress 135

personal income tax 78-79, 81, 85

piracy of technology 48, 50-51, 115-

116

policy recommendations xiv-xxii

pollution by firms 86

portfolio management 72

power supply 122

prices

market competition and $47-48$, $51 \underline{n} 5$

quality affected by 48,50

private enterprise, historical perspective 9-15

private firms

acknowledgement of xi

as listed firms 68

capital size distribution 25

chambers of commerce assisting 126

contribution to economy $15-27$

defined 17

development factors xiii-xiv

distribution (regional) 24, 26

distribution (sectoral) 24, 25-26

employment share 13,16

GDP share $16-17,19$

growth of 12-14, 15, 16, 19

industrial output 18

loan access 59, 124

loan utilisation 16,69

output share 16

ownership evolution 21-24

ownership types 23-24, 25

perceptions of 134-136

policy recommendations xiv-xxii

profitability $38-40$ role of xxii

tax contribution 82-89

TSPE definition 13

privatisation

forms of 22

gaizhi and 20-21

implementation program 15

in Shunde 22

SOEs 16, 17-24, 41

Procedure for Registration for Private Enterprises 41므

profitability

firm size and 40

market competition and 38

of industry 39,40

property rights, policy

recommendations $\mathrm{xx}-\mathrm{xxi}$

public services 122-123

Pudong 71

Qiaotou 30, 32, 127

Qiaotou Button Chamber of Commerce 127

quality, prices affecting 48,50

$\mathrm{R} \& \mathrm{D}$ (research and development) $\mathrm{xx}$ 'red hat' firms

cause for emergence 59

creation of 21,23

defined 14

guakao firms as 46

in Beijing 14, 46

in Shunde 14, 21

official collectives as 17

reform

economic xi-xiv, xxii

education and training xxi

enterprise reform policy $27 \underline{n} 11$

financial xiv-xvi, 71-73

getih $u$ as a response to 12 
government xix, xxii, 136n 1

legal system $\mathrm{xx}-\mathrm{xxi}$

private investment $x x i-x x i i$

property rights $\mathrm{xx}-\mathrm{x} \mathrm{xi}$

rent-seeking behaviour limited by 86

rural 12

taxation and revenue $x v i i-x v i i i$ technical innovation $\mathrm{xx}$ urban 12

registered capital, defined $41 \underline{\mathrm{n}} 2$

registration of firms $117-120,130$, 132

Regulation for Labour Management in Private Enterprises $99 \mathrm{n} 3$

regulations (see laws and regulations) Regulations on Protecting and Managing New Products 127

renminbi currency $71,74 \underline{n} 5,135$

rent-seeking behaviour

distribution of xix

eradication of 21

factors encouraging 131

getibu fees and 119

taxation reform limiting 86

research and development $(\mathrm{R} \& \mathrm{D}) \mathrm{xx}$

resident status $105,109 \underline{\mathrm{n}} 3$

resource usage $85-86$

revenue (see fees; taxation)

risk management 64-65, 72

Rongqi 128

rural reform and growth of getihu 12 rural sector

employment of migrants from

98-99

getihu in 12

informal loans in 67-68

social security benefits for 107 , 108

Russia, privatisation in 132 (see also Soviet Union)

salaries (see wage differentials) sales, firm size and 34-35, 36 sample enterprises

capital growth $37-38,41 \underline{n} 3$ industrial distribution $35-36$

profiles 29-31

profitability $38-41$

size $31-35,41$

sampling strategy

analysis 6-7

information sources $8 \mathrm{n} 2$

localities 4

stratified random sampling approach $4-5,8 \underline{n} 7-\underline{n}$ ?

variable standard deviation in 41 n 4

self-employment $11,27 \underline{\mathrm{n}} 3$

'separate taxation system' 78

SETC (State Economic and Trade

Commission) $2,3,16,27 \underline{n} 11,72$

Shandong 20

Shanghai

foreign banks 74

Minsheng Bank 72, 73, 126

source of expertise 94,95

stock market 22,68

taxation 85

technological piracy 51

share ownership, by employees 70

Shehong 23

Shenzhen

MD listed 111

stock market $22,68,71,111$

Shunde (Guangdong Province)

business partners 49

chambers of commerce 126

City Credit Union 64

employment 37

finance constraints $58-59$

Firm J (case study) 48,70 
firm profitability 40

Firm S (case study) 87

firm size (no. of workers) 32, 33, 34,41

firm size (sales and capital) 35

Guizhou Chamber of Commerce (case study) 128

industries 35

information dissemination 123

initial capital 53-54, 55

institutional capital 132, 133

land use rights 63

laws and regulations $120,121-$

$122,131,136 \mathrm{n} 1$

listed firms 68, 95

loan applications 61

managers' education 100, 102

managers' experience 103

market barriers 44,45

MD (case study) 111 (see also $\mathrm{MD})$

medicine distribution 45

partnership firms 92

privatisation $20,31,133,135$

privatisation (case study) 22

profile 29

public services $122-123$

'red hat' firms 14, 21

rent-seeking behaviour 21

resident status 105

resource usage tax $85-86$

social security contributions 107 , 108

'stopping bleeding project' 21

survey criteria $2,4,5,6-7$

taxation $80,85,86-87$

technological innovation 112

technological piracy 51

turnover rate $57-58$

TVEs 4, 31, 32

wage rate $105-106$
Shunde's privatisation (case study) 22

Sichuan (see also Chengdu; Deyang;

Mianyang)

ACFIC loan scheme 62

gaizhi (case study) 23

profile 29

public services $122-123$

'red hat' firms 14, 21

Sichuan Chamber of Commerce 126, 135

survey criteria 4,5

wage rate $109 \underline{n} 4$

Sichuan Chamber of Commerce 126, 135

Silicon Valley (USA) 94

single industrial and commercial proprietor (see getihu)

SOBs (state-owned banks) 53-54

social capital $134-136$

social security system 106-108

SOEs (state-owned enterprises)

access to loans 59

as business partners 49

as listed firms 68

enterprise arrears 56

GDP share 19

liability of 120

market competition and 47

private sector as model for 15

privatisation of $16,17-24,31$, 41, 101

reforms affecting employment 98

size of 97

workers' benefits 98

sole ownership

benefits of 90-91

laws governing 13-14

relative importance of 23-24, 25 taxation 120

Soviet Union 9, 10 (see also Russia) special consumption taxes 78,79 
spouses, as business partners 92

'Star Plan' 126, 136n 4

State Bureau of Foreign Reserve Management 71

State Bureau of Industry and Commerce Management (see BICM)

'state capitalism' 9

State Council 11, 14

State Economic and Trade Commission (SETC) 2, 3, 16, $27 \underline{n} 11,72$

state-owned banks (SOBs) 53-54

state-owned enterprises (see SOEs) state-private cooperatives 9

Stipulations on the Protection of Private Firms 117

stock market

admission criteria 73

Hong Kong Stock Exchange 59, 71, 74n 4, 95, 111

New York Stock Exchange $7 \underline{4} \underline{n} 4$

policy recommendations xvi

restrictions in 22

Shanghai Stock Exchange 22, 68

Shenzhen Stock Exchange 22, 68, 71,111

solving incentive problems 70

'stopping bleeding project' 21

subsidiaries 96-97

Suggestions on Revitalizing Small Stateowned Enterprises 27ㅁ11

survey

geographic distribution 2

implications xxii

methodology 2-4, 8n3-n 4

objectives 1

overview 1-2

sampling strategy $4-8,8 \underline{\mathrm{n}} 2,8 \underline{\mathrm{n}} 7-$ n9, 41 n 4 selection criteria 4-5

taxation (see also fees; value-added tax) adjustment tax on capital investment 80

burden distribution $82-89,120$

corporate income tax 78-79, 81, 83-84, 85

evasion of $79,84,87$

Firm S (case study) 87

implementation problems $80-82$, 89

personal income tax $78-79,81$, 85

policy recommendations xvii-xviii post-1994 78-80

pre-1994 78

privileges 84,86

rates 85

resource usage tax $85-86$

revenue distribution $78-79$

technical capacities, factors affecting 113-114

technological innovation (see also technology)

MD (case study) 111

pattern of 110-116

policy recommendations $\mathrm{xx}$

technology

market competition and 47

pattern of emergence 110-116

piracy of 48, 50-51, 115-116

telecommunications $\mathrm{xx}, 122,124$

telephone services 122

Tentative Stipulations on Private Enterprises (TSPE) 13, 14

Tentative Stipulations on the Registration of Individual and Private Enterprises (TSRIPE) 117, 119, 131

Tianjin 14 
tonggou tongxiao, policy of 9-10

'Torch Plan' 126, 136n 4

township and village enterprises (see

TVEs)

trade unions $98,99,99 \mathrm{n} 4$

training $\mathrm{xxi}, 104-105,108,114$ (see also education)

TSPE (Tentative Stipulations on

Private Enterprises) 13, 14

TSRIPE 117, 119, 131

turnover rate $57-59,74 \underline{n} 1$

TVEs (township and village

enterprises)

access to loans $59,74 \underline{n} 2$

informal loans to 67

in Shunde 4, 31, 32

in Wenzhou 133, 134

market competition and 47

twenty sixth document 106

unemployment (see also employment)

accompanying gaizhi 23

influence on private economy 11

self-employment reducing 11 ,

$27 \mathrm{n} 3$

unions, trade 98, 99, 99n 4

United States of America (USA) 94, $99 \mathrm{n} 2$

urban reform and growth of getihu 12

value-added tax (VAT) (see also fees; taxation)

payment discrepancies 82,84

rate of 80

receipts for $80-81$

restricting investment 114

revenue distribution 78,79

types of $89 \underline{n} 1$

'venture capital' xvi wage differentials $104,105-106$

wage-earning factories 10

Wanbao 31

W Arts Co. Limited (case study) 46

Wenzhou (Zhejiang Province)

arbitrary fee imposition 89

bank finance (case study) 69-70

business associations 127

capital growth rate 37

collateral 62-64

credit associations 68

finance constraints 59

firm profitability 40

firm size (no. of workers) 32, 33, 34,41

firm size (sales and capital) 36,37

Firm TZ (case study) 95

HDL (case study) 116

industries 35

information dissemination 123

initial capital 53-54, 55

institutional capital 133,134

land price 30

land use rights 63

loan applications 60,61

managers' education 101, 102

managers' experience 103

market barriers 44,45

outside expertise 94

private sector development 30

profile 29

public services 122-123

social security contributions 108

survey criteria $2,4,5,6-7,8 \mathrm{n} 8$

taxation 85

technological innovation $110-$

111,112

turnover rate 57-58

TVEs 133,134

wage rate $105-106,109 \mathrm{n} 4$ 
Wenzhou Garment Chamber of

Commerce (case study) 127, 129

workers

employment benefits $98,99 \underline{\mathrm{n}} 3$

living standards 98-99

World Trade Organisation (WTO)

xxi

Wu Bangguo 27n11

Xinjin 31

Yibin 23

Yongiia 127

Zhejiang 2 (see also Wenzhou)

Zhongshan 31, 86

zhuada fangxiao, policy of 20

Zhucheng 20 